Fall 1934

\title{
1934 Cedrus Yearbook
}

\section{Cedarville College}

Follow this and additional works at: https://digitalcommons.cedarville.edu/yearbooks

Part of the Higher Education Commons, Organizational Communication Commons, and the Public Relations and Advertising Commons

\section{Recommended Citation}

Cedarville College, "1934 Cedrus Yearbook" (1934). Yearbooks. 74.

https://digitalcommons.cedarville.edu/yearbooks/74

This Book is brought to you for free and open access by DigitalCommons@Cedarville, a service of the Centennial Library. It has been accepted for inclusion in Yearbooks by an authorized administrator of DigitalCommons@Cedarville. For more information, please contact digitalcommons@cedarville.edu. 


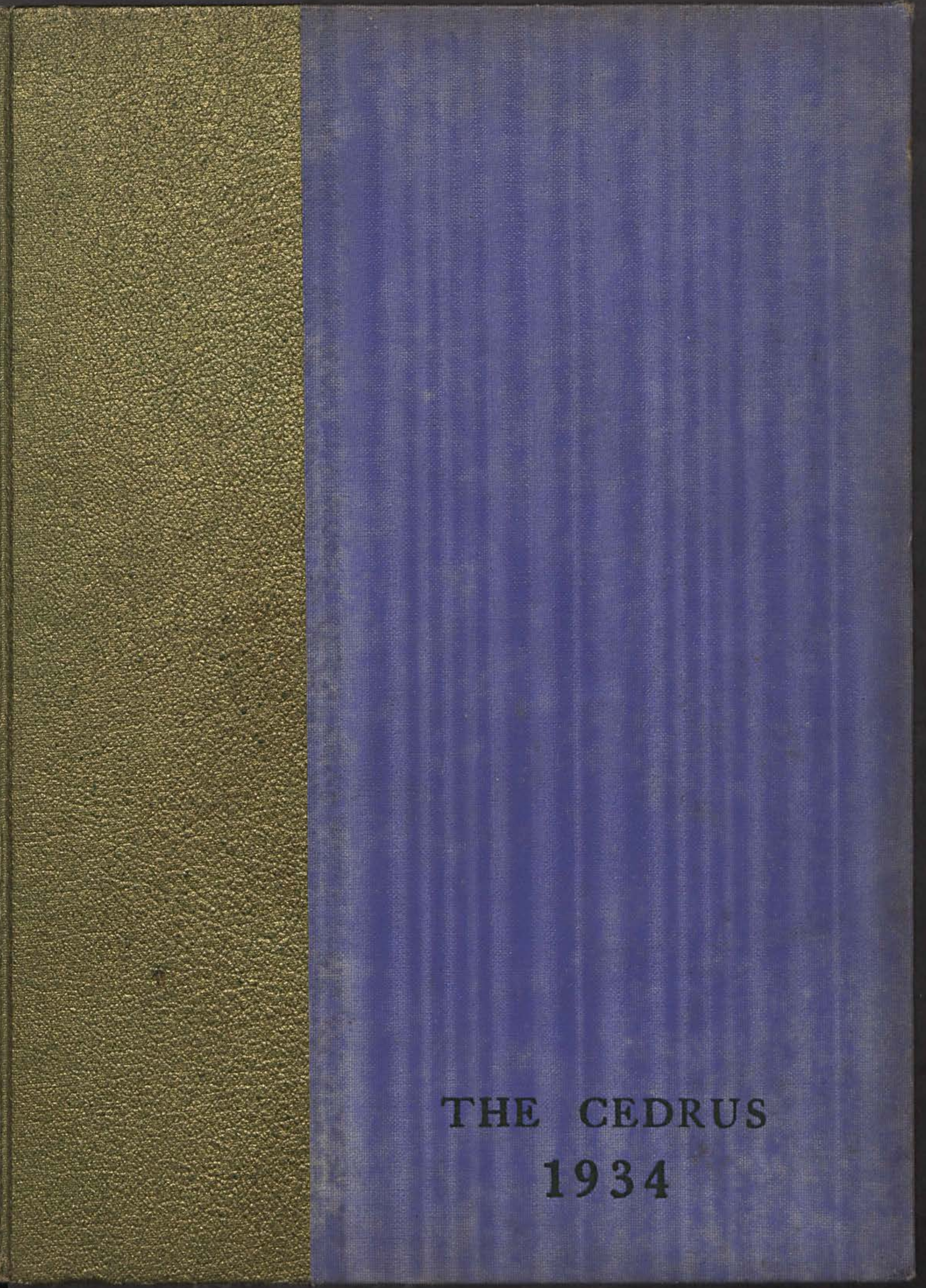





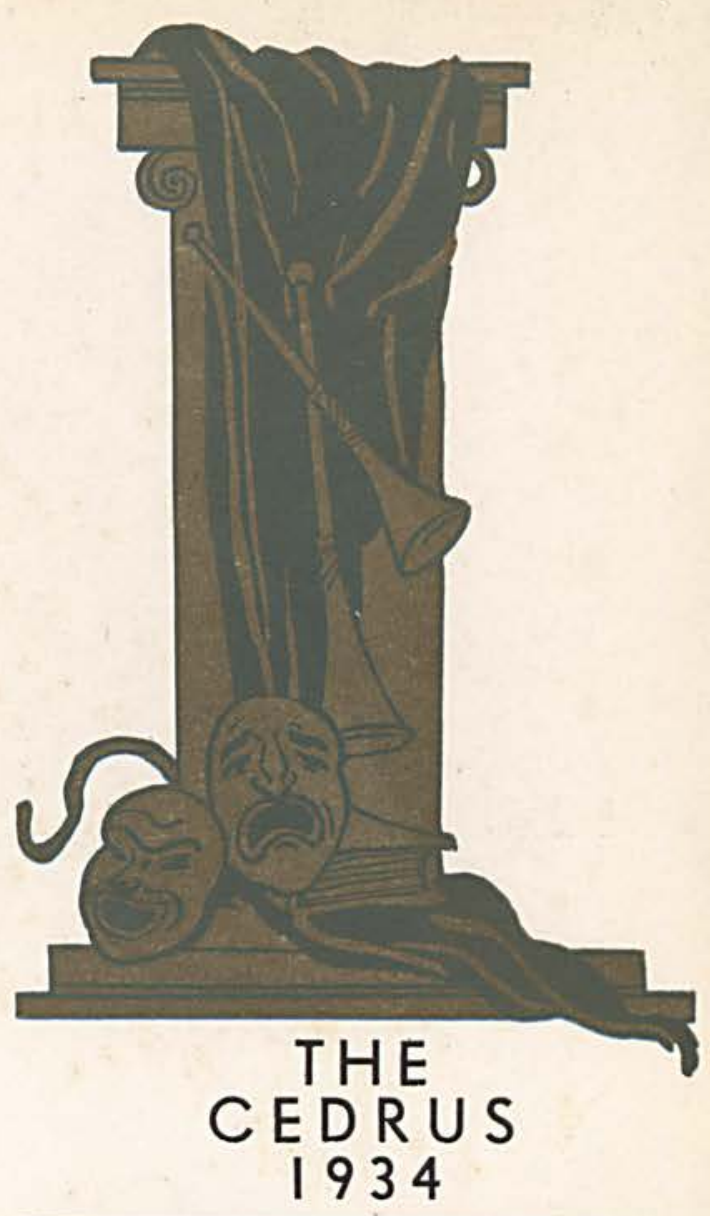




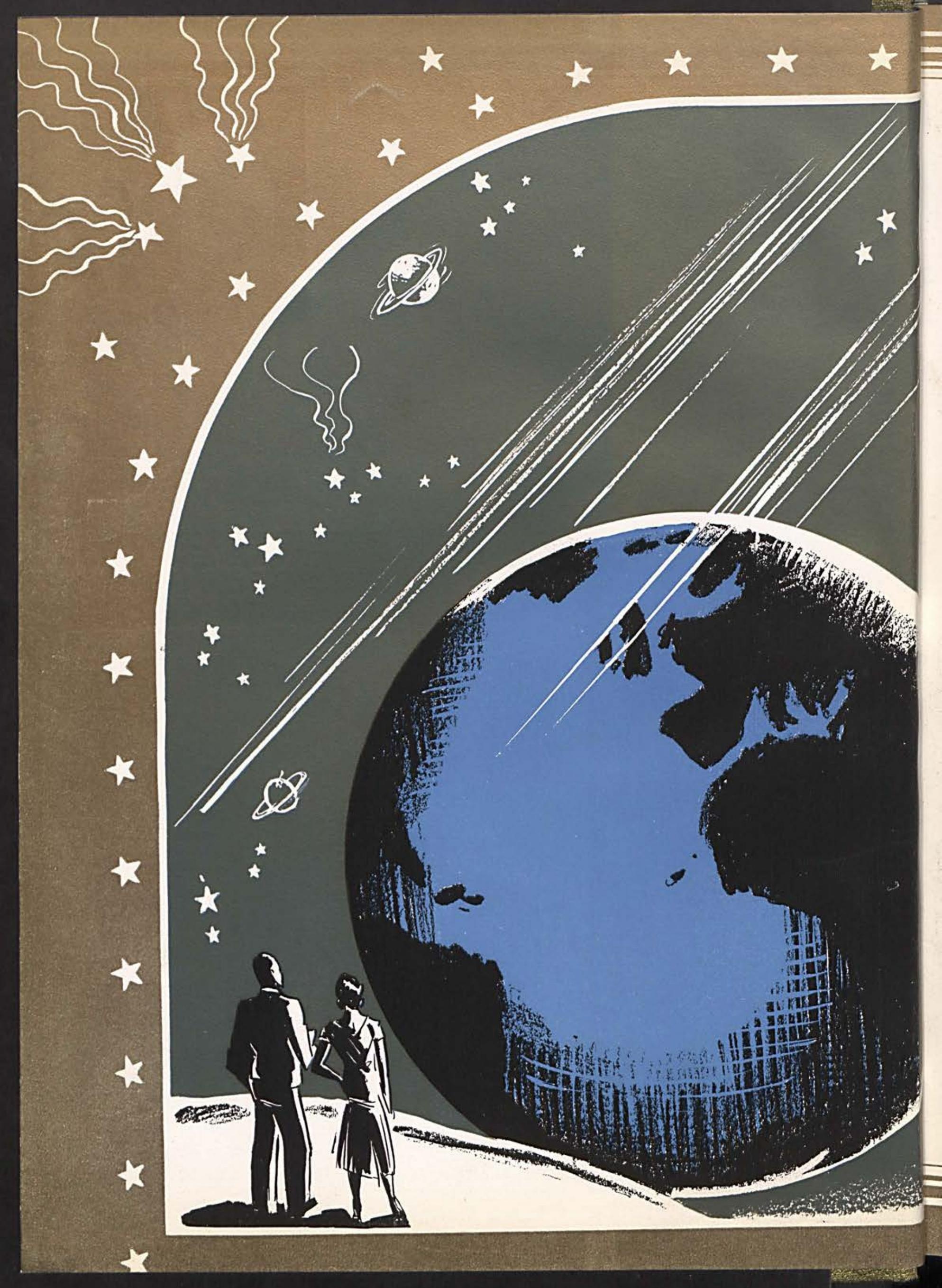




\section{THE CEDRUS}

VOLUME TWENTY.

装

BEING A DRAMATIZATION

IN FOUR ACTS OF

THE FORTIETH YEAR OF

CEDARVILLE COLLEGE,

AT CEDARVILLE, OHIO,

FROM SEPTEMBER, 1933

TO JUNE, 1934.

采

PUBLISHED BY THE

CEDRUS STAFF OF

NINETEEN THIRTY-FOUR. 


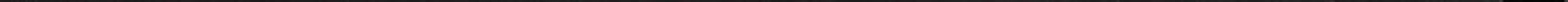


Cedarville College - her glorious past her promising future.

Her Past - illustrious graduates - eager students - revered professors - victorious teams - live-wire organizations friendships - traditions - loyalties.

Her Future - consistent growth - improved facilities - continued service more friendships - more traditions more loyalties.

To Cedarville College - the glories of her first forty years - the hopes of the coming aeons. -

We Dedicate This 1934 Cedrus.

The Staff

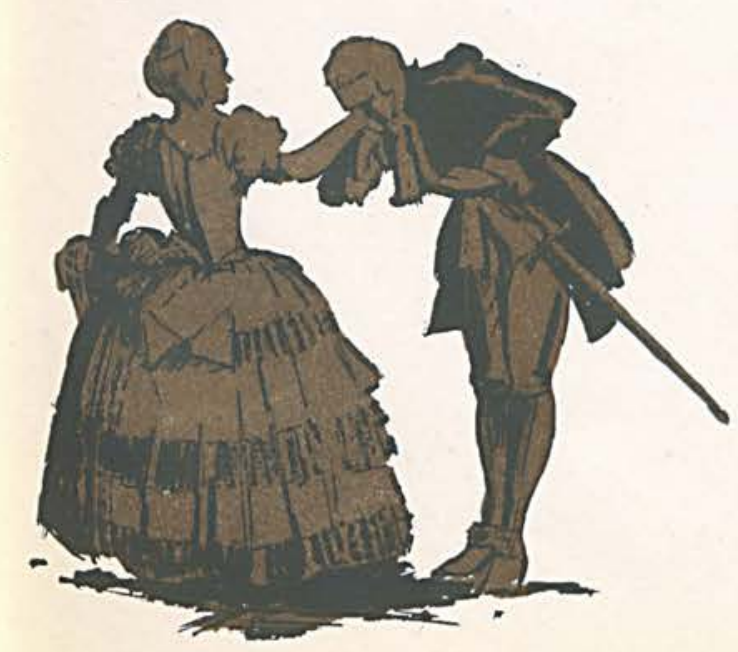




\section{OVERTURE.}

O Cedarville, our college dear, For loyal youth so strong, For constant faith without a fear, Through all the years so long! O Cedarville! O Cedarville! Home of our student-days. Forever may thy name abide And lasting be thy praise. O Cedarville, we live for thee With faith unfaltering; We live, we love, we trust for thee;

- Be glad and let us sing:

O Cedarville! O Cedarville! Our trust in thee maintain; Confirm thy strength in purity, Thy honor to retain.

W. R. McChesney.

al

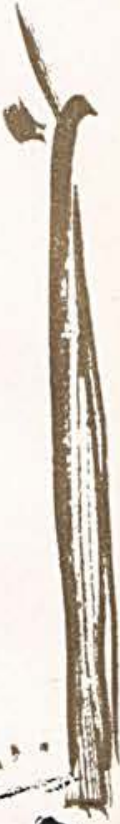

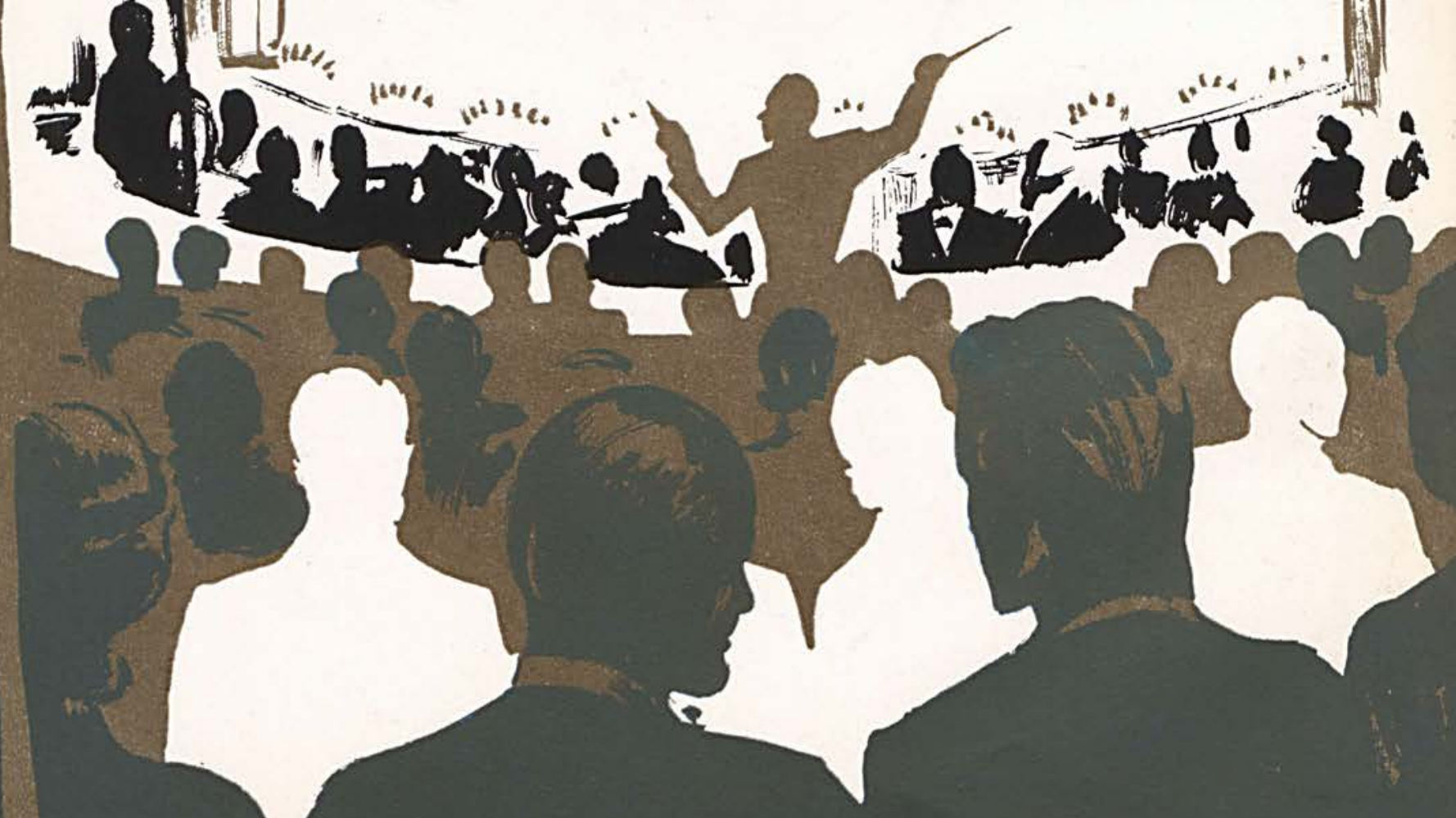


PROLOGUE.

On this fortieth anniversary of Cedarville College, it has been our aim, as a Cedrus staff, not only to produce a crystallization of this year's activities, but a brief review of those forty years as a whole.

Such an ideal could be attained only through the cooperation of many people throughout the year.

May we here express our appreciation to all who have so helped, as we present the fruit of our labors - the 1934 Cedrus - to the students, alumni, and friends of Cedarville College.

The Editor. 


\section{DIRECTORS}

\section{准}

WALTER KILPATRICK DORIS HARTMAN Editor-in-chief ARTHUR DONALDSON Business Manager ELEANOR BULL. Asst. Editor HOMER MURRAY Asst. Business Manager W. B. McCALLISTER....Asst. Advertising Manager LOIS CULTICE. Organizations Editor ROBERT ROSS Sports Editor DOROTHA CORRY. Music Editor CARMA HOSTETLER Art Editor JANE WEST History Editor GLENNA BASORE History Editor JOHN MURRAY. Diary Editor REGINA SMITH. Diary Editor DONALD BURKERT. Features Editor ERROL MACKNIGHT ROBERT THOMPSON. Snapshots Editor Prof. O. W. KUEHRMANN Snapshots Editor Faculty Advisor

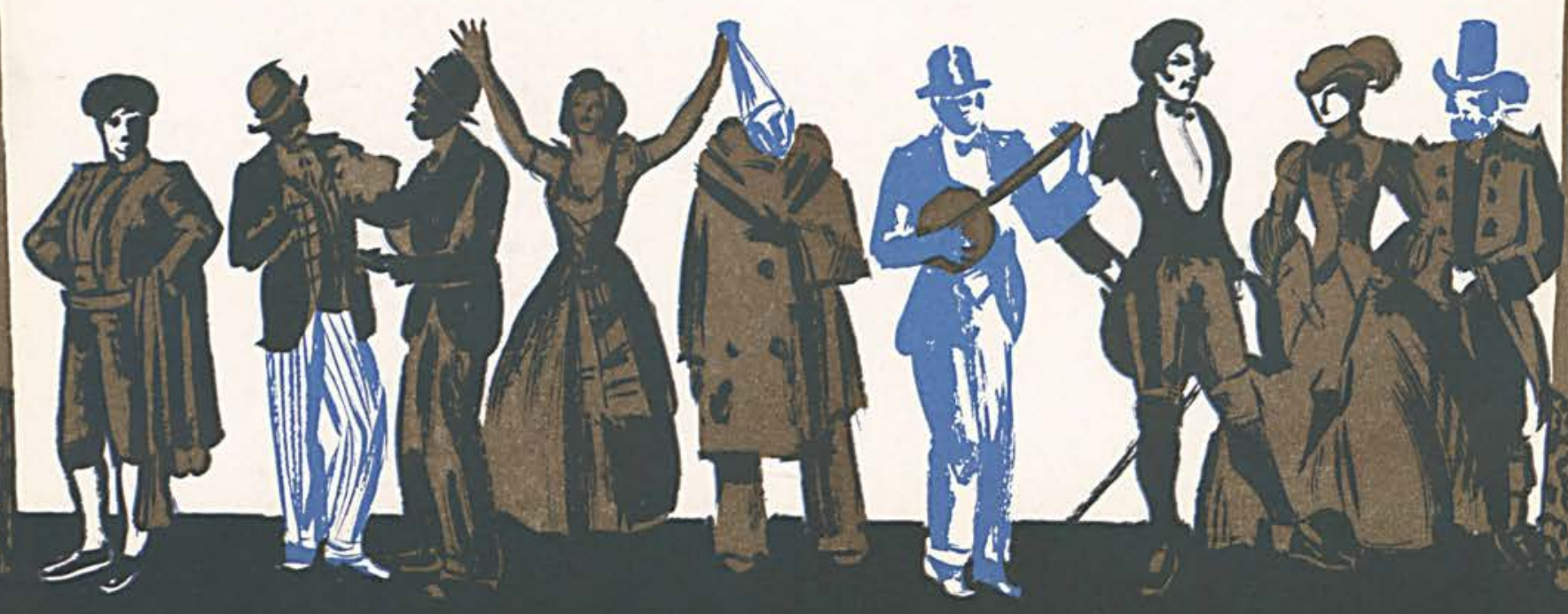



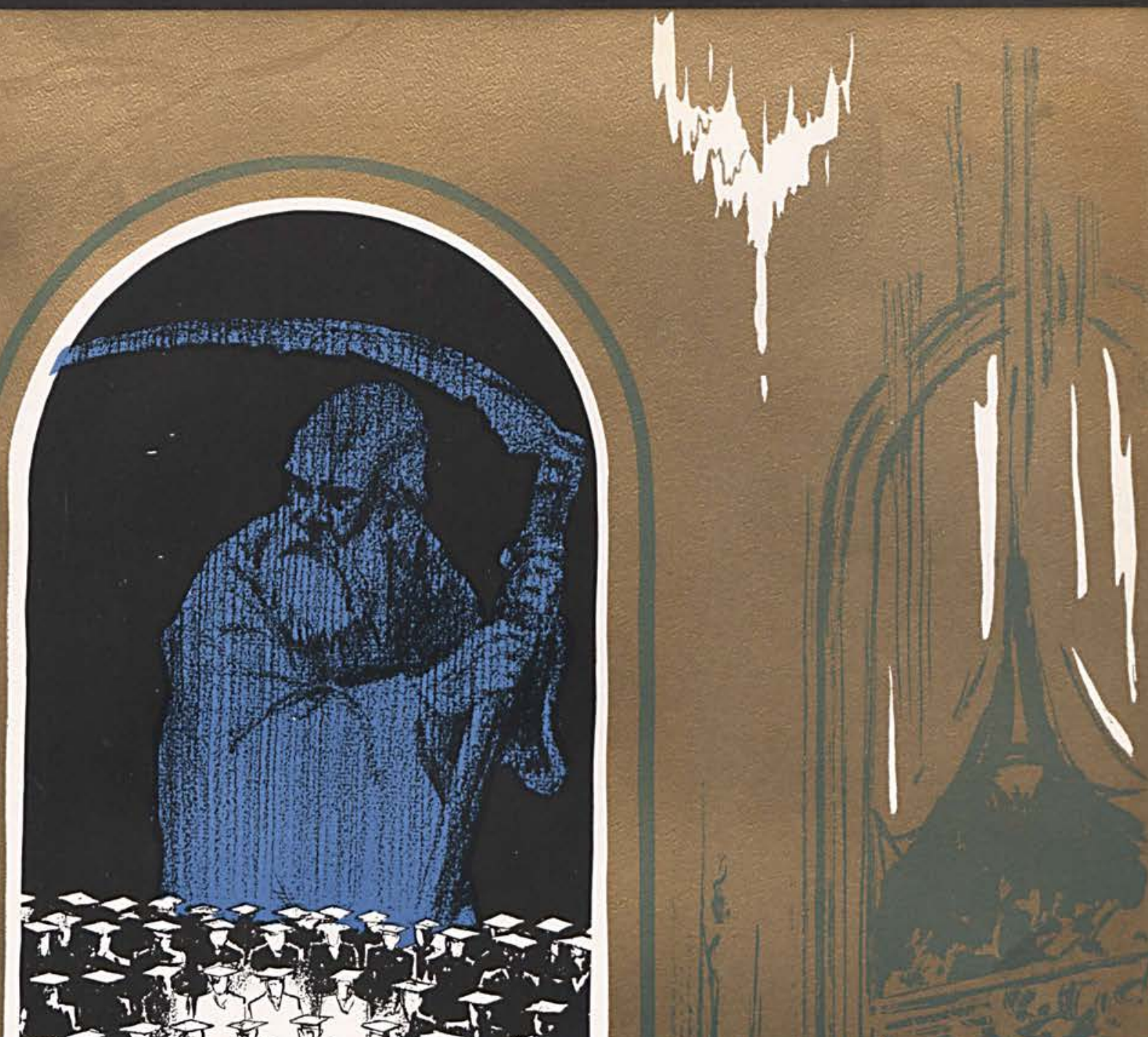

10
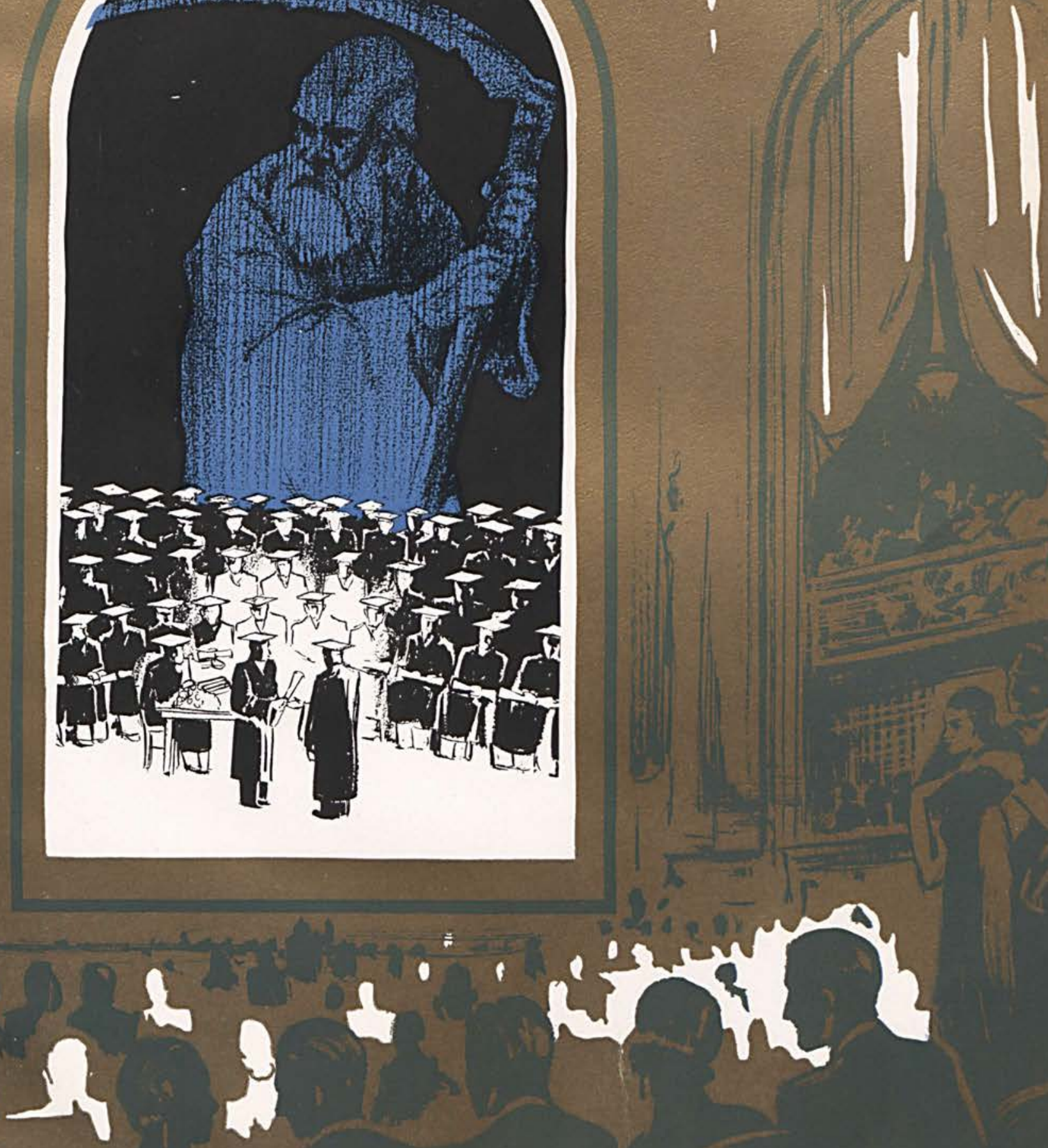

\section{ACT ONE ... COLLEGE}




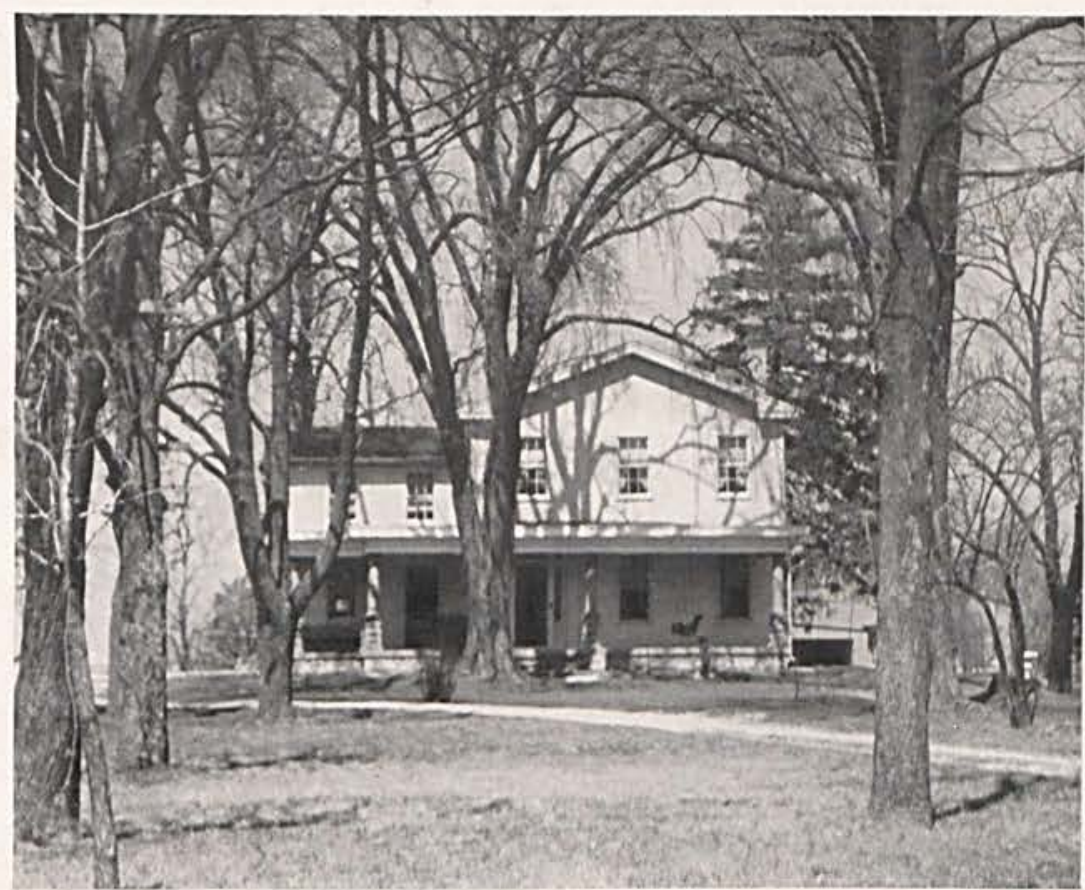

\section{EARLY HISTORY OF CEDARVILLE}

The idea of establishing an institution for higher education in Cedarville originated with the General Synod of the Reformed Presbyterian Church in America, a denomination representative in this country of the historic Covenanter Church of Scotland. Dr. Hugh MacMillan, for many years pastor of the Cedarville congregation, manifested a warm interest in the cause of higher education, and was the principal of a classical academy in Greene County, which he conducted successfully in addition to his pastoral labors. In January, 1887. Cedarville College was duly chartered by the state of Ohio. The enterprise then slumbered for a few years for various reasons, but in May, 1894, a fresh and most successful start was again made. The General Synod elected Rev. David McKinney of Cincinnati, Ohio, president of the college, and directed the Board of Trustees to open the college in the autumn of the same year. The Board accordingly chose a faculty, and on Wednesday, September 19, 1894, the college was formally opened, conducting classes in the historic building pictured above. 


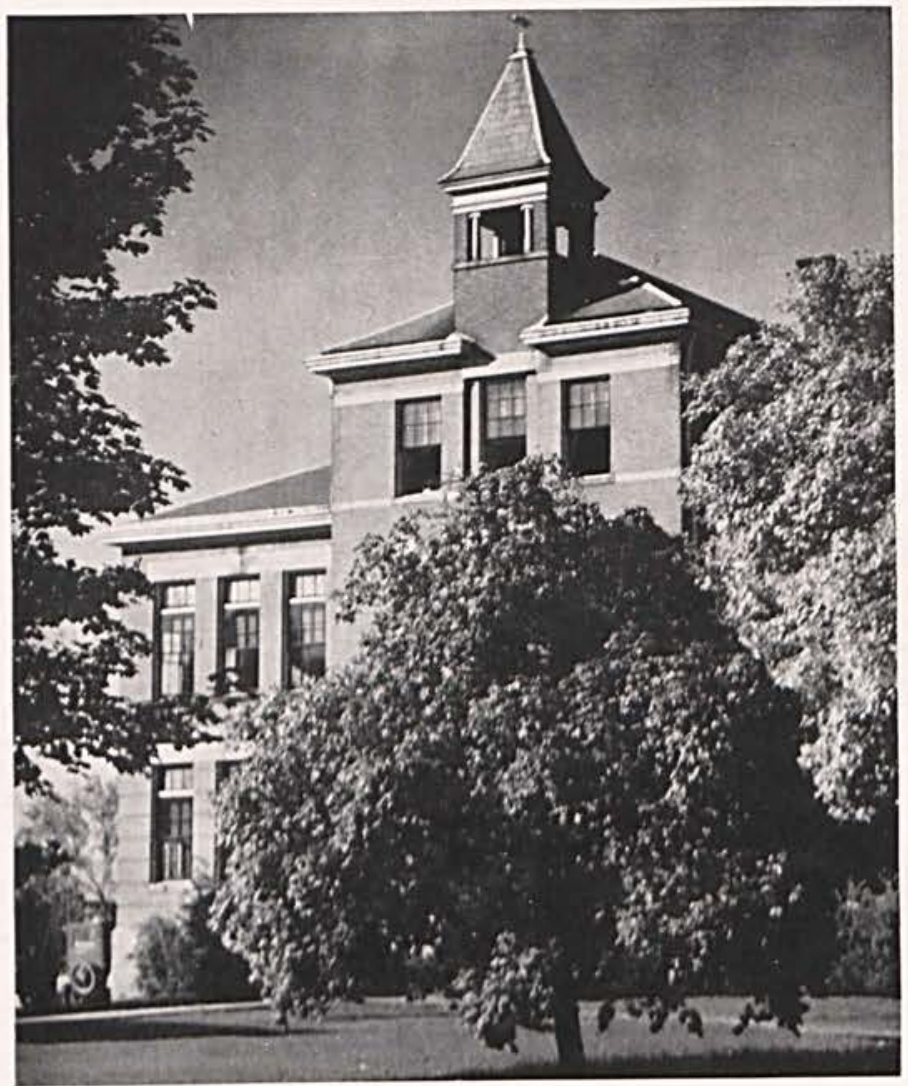

For nearly forty years the Main Hall of Cedarville Col. lege has stood, surrounded by cedar trees, in the middle of the college campus. Its ivy. covered walls have become dear to all who have studied within them. This old building brings back memories of the happiest days of the lives of Cedarville alumni. It represents to them all that Cedar ville College stands for - the highest ideals of life.

The catalogue of 1896 describes the building thus: "The basement contains a gymnasium, a chemical room, coal cellars, and the heating apparatus. On the first floor there are four class rooms, the chapel, and the president's room. On the second floor, four class rooms, a large lecture room, and the library. Two large society rooms occupy the entire third floor. The building is surmounted by a tower." Though several buildings have been added, "Old Main" remains the center of Cedarville College life.

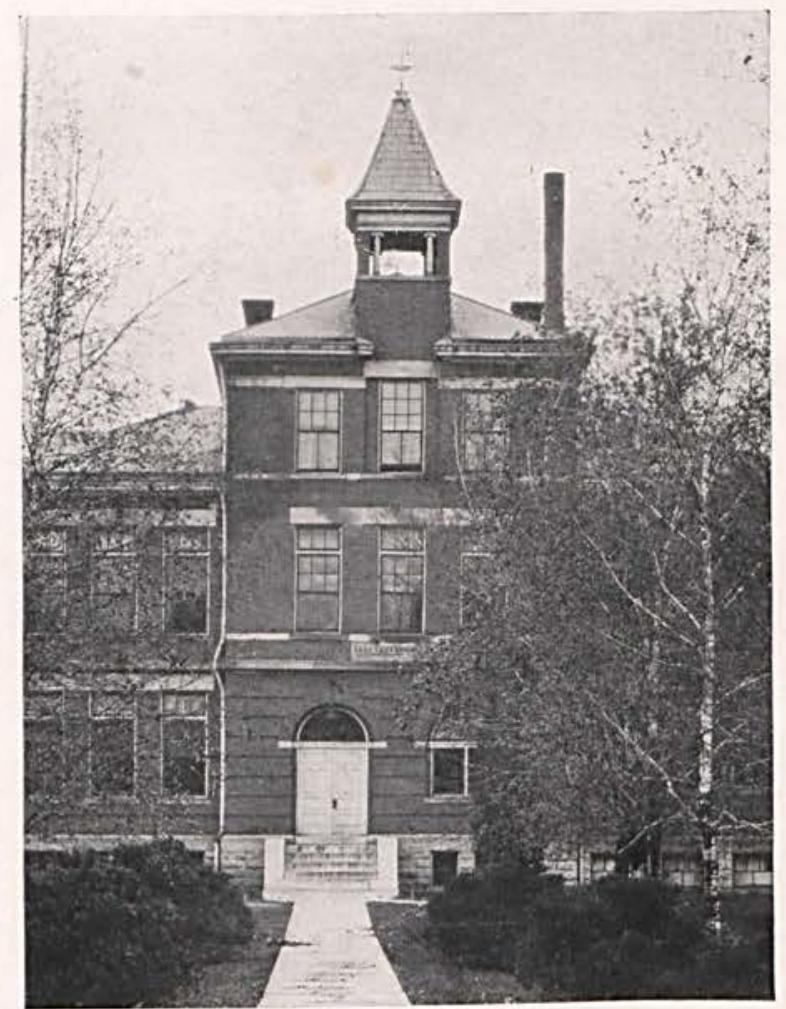


Cedarville College's department of science was originally located in the rooms now oc cupied by Prof. Steele and Prof. Ault. In 1909, the partition in the second-story room was removed to provide a combination laboratory and recitation room. Here the science department had its head. quarters until the fall of 1923 when the new science building was ready for occupancy.

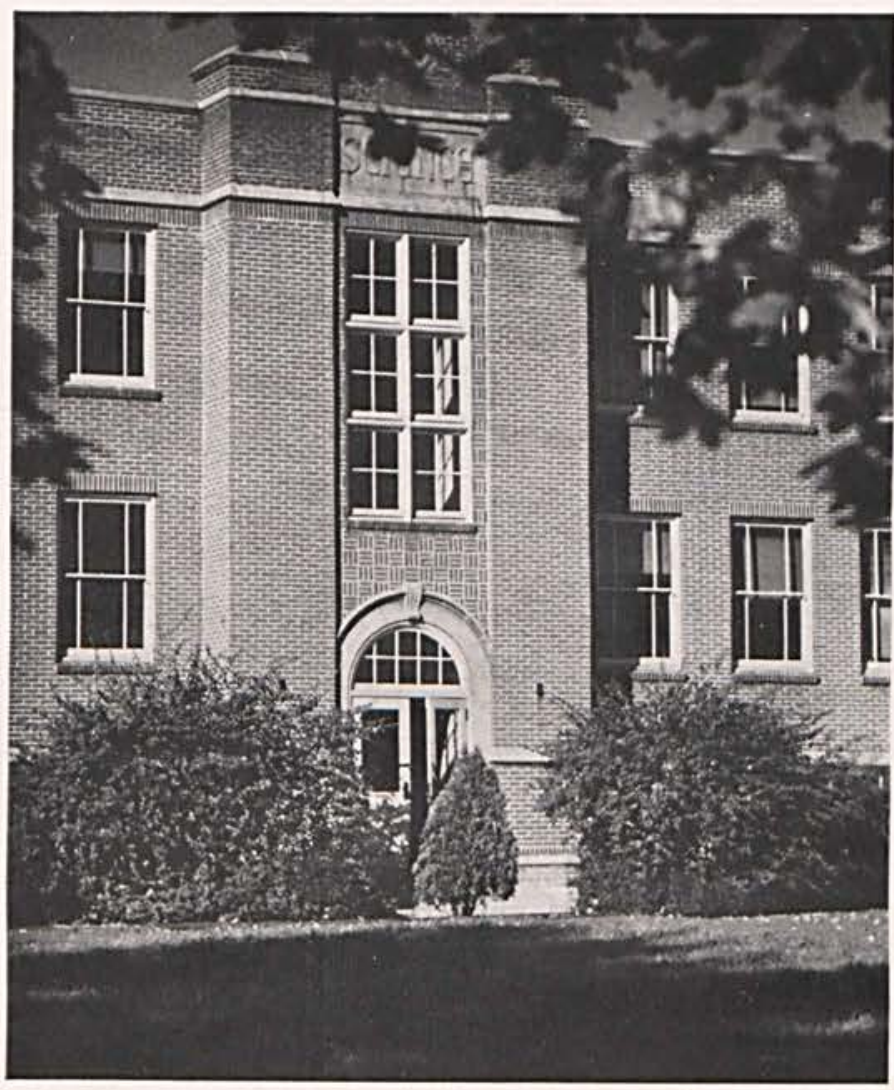

This fine new building, equipped with complete modern apparatus, has been the delight of the instructors and as. piring young scientists. The basement and first floor contain the chemistry and physics laboratories and class rooms. On the second floor are located the botany and zoology laboratories and classrooms. This year has seen the addition of an adequate library devoted to the inter ests of the department of education. 


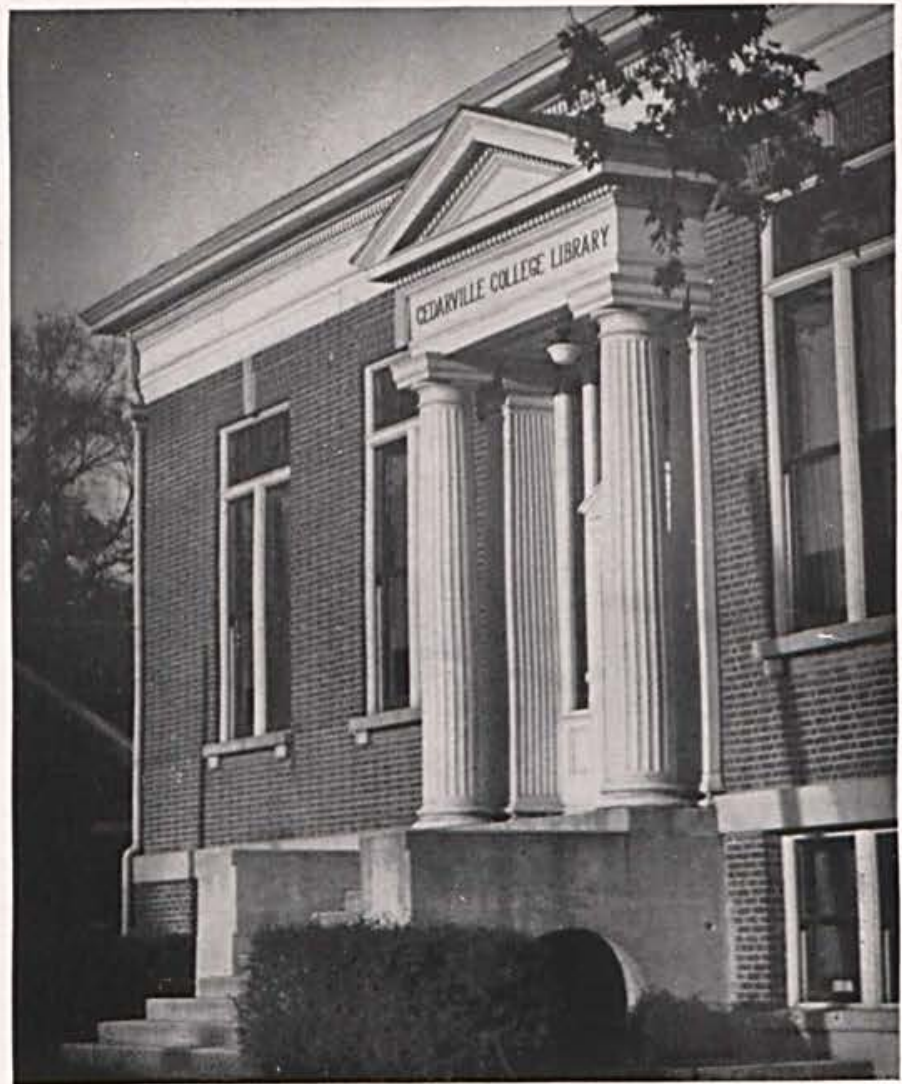

When one thinks of college, he must necessarily think of books, for books play an enormous part in a college education. When the Main Hall was buil in 1896, one room was set aside as a library, but this room soon became too small to accommodate the increasing number of books.

Therefore, in December, 1905, Andrew Cornegie generously donated $\$ 12,000$ to erect a library building, with a capacity of 17.000 volumes, for Cedarville College. The college and community cooperate in maintaining and enjoying the library. The basement of the library at the present time furnishes quarters for the "Eating Club," the literary society, and the department of music.

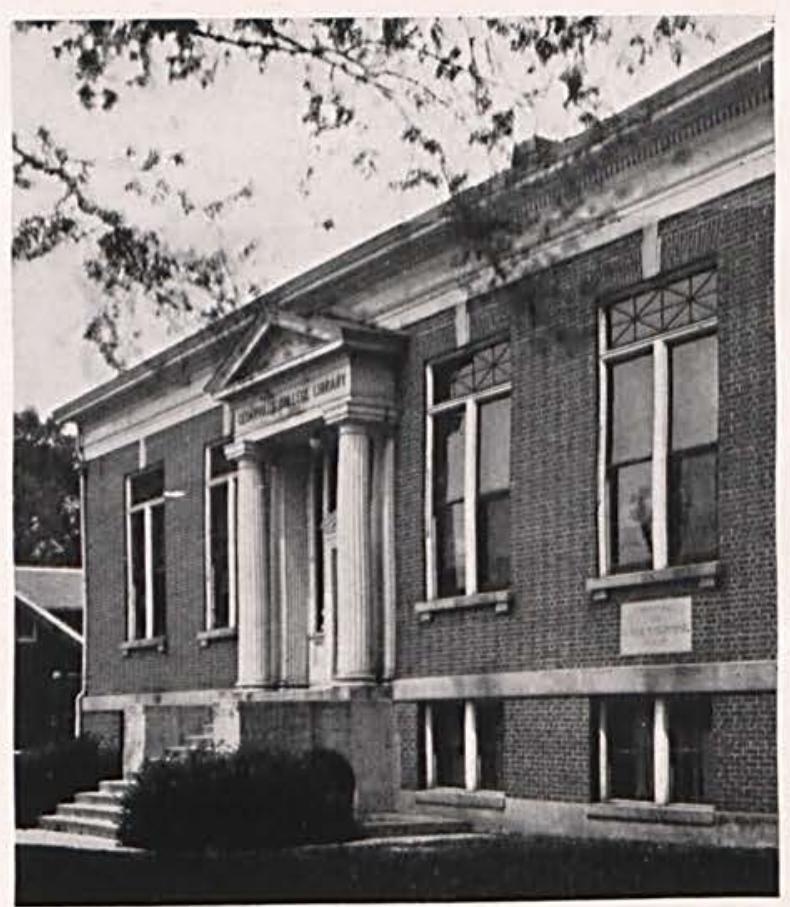

Page Fourteen 
When the main building was erected in 1895, space was provided for a department of physical education. A gymna. sium, furnished with complete apparatus, was opened in 1896 in the basement of the main building. All students had free access to this gymnasium and "college authorities promptly checked any tendency to brutality and excess in athletic contests."
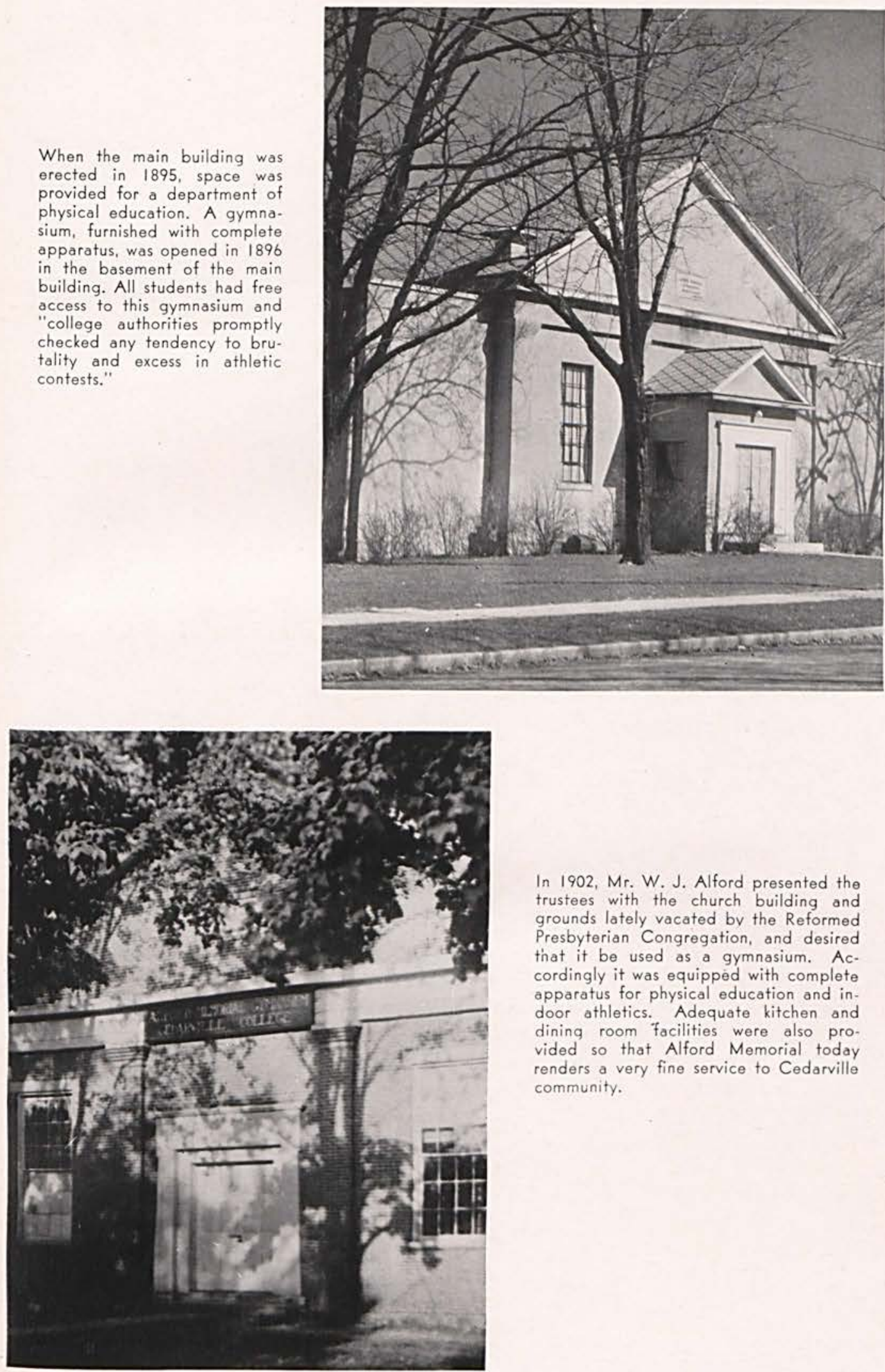

In 1902, Mr. W. J. Alford presented the trustees with the church building and grounds lately vacated by the Reformed Presbyterian Congregation, and desired that it be used as a gymnasium. Accordingly it was equipped with complete apparatus for physical education and in door athletics. Adequate kitchen and dining room facilities were also provided so that Alford Memorial today renders a very fine service to Cedarville community. 


\title{
IN MEMORIAM
}

\section{DR. DAVID McKINNEY}

\author{
Born - May 20, 1860 \\ Died - April 26, 1934
}

President of Cedarville College................ 1894-1915

President Emeritus .........................1915-1934

Rev. David McKinney, D.D., first President of Cedarville College, was born in Philadelphia, May 20, 1860. His parents were members of the Third Reformed Presbyterian Church, of Philadelphia, with which he also united at the age of fifteen. He received his literary education in the Philadelphia Public Schools, the University of Pennsylvania, and the Reformed Presbyterian Theological Seminary. He was licensed to preach April 3, 1883; and on October 2, 1884, was ordained pastor of the Washington Congregation, near Elgin, III. In the spring of 1888 he received a call to the First Reformed Presbyterian Church of Cincinnati. Upon the merger of this congregation with the First Presbyterian Church he became pastor and served until the merger of the Covenant and First congregations.

In 1891 he was married to Miss Carrie Chapin of Cincinnati. During his residence in Cincinnati he was both actively and officially connected with many of the religious and reform movements of the city. In May, 1895, Wittenberg College conferred upon him the degree of D.D. He was also one of the examiners of the University of Pennsylvania. At the meeting of the General Synod held at Coulterville, III., in May, 1894, the Synod, on the recommendation of the Board of Trustees, elected him first President of Cedarville College. At that time the college was largely a prospective institution. Dr. McKinney took hold of the work with such energy and determination that from a plan on paper it evolved into a reality.

As president of the college, Dr. McKinney was acquainted with every student and worked with great zeal for the success of the institution. Since his resignation as President in 1915, Dr. McKinney has kept in close touch with the school, serving very efficiently on the Board of Trustees. Cedarville College owes in large part her very existence to Dr. McKinney. It is difficult to express our appreciation in words. His death in Cincinnati on April 26 took a friend from Cedarville College who can never be replaced. 


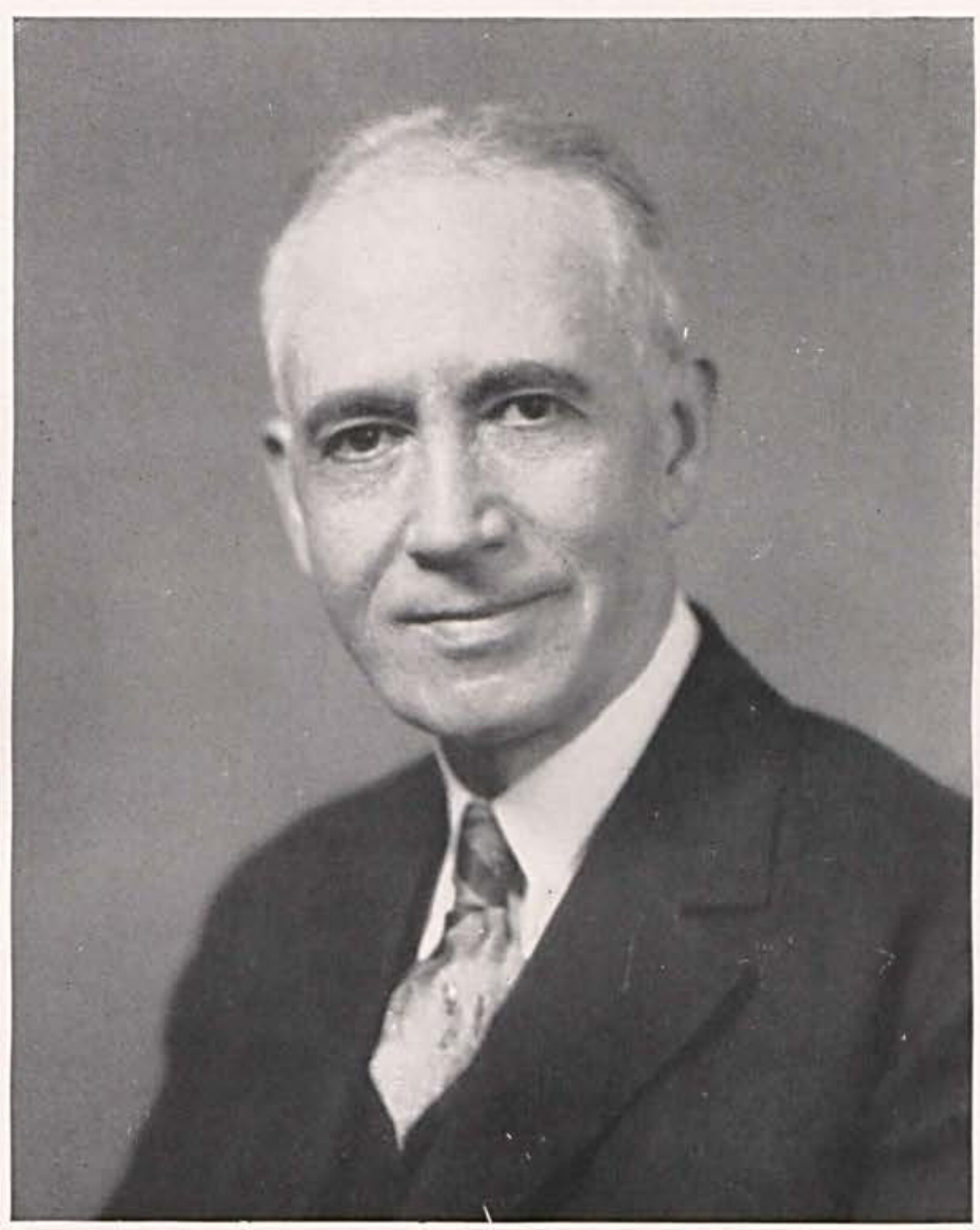

DR. McCHESNEY

The history of the forty years of Cedarville College is also the history of forty years of faithful service of one who was the first elected teacher in the college, and who has been our beloved president in the past nineteen years.

Wilbur Renwick McChesney was born July 7, 1871, in Lawrence County, Pennsylvania, of Scotch Covenanter parentage. He had an unquenchable thirst for knowledge and refused to allow anything to prevent his attaining the best education available. He studied at Franklin College where he received his A. B. degree in 1892, and his M. A. in 1894. He earned his Ph.D. degree from Franklin College in 1906, and was honored with the degree of D.D. by Tarkio College in 1915.

Dr. McChesney was ordained as a minister of the gospel by the Reformed Presbyterian Church in 1900.

In 1894 Dr. McChesney was called to Cedarville College as the first professor of an cient languages, and was chosen to succeed Dr. McKinney as president in 1915. 


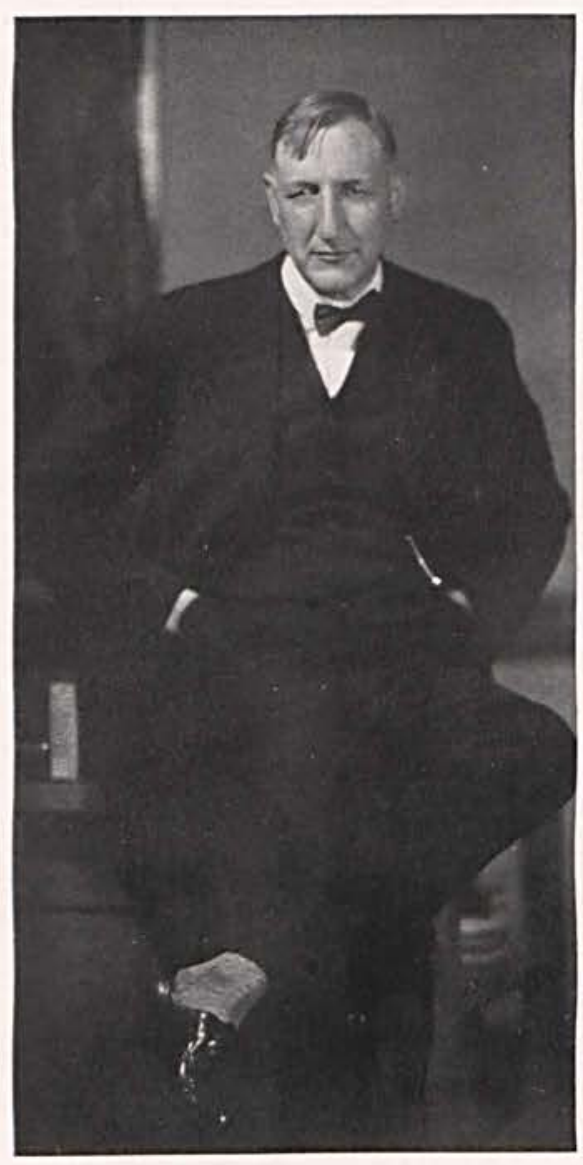

Prof. F. A. Jurkat, LI. D.,

Languages and History

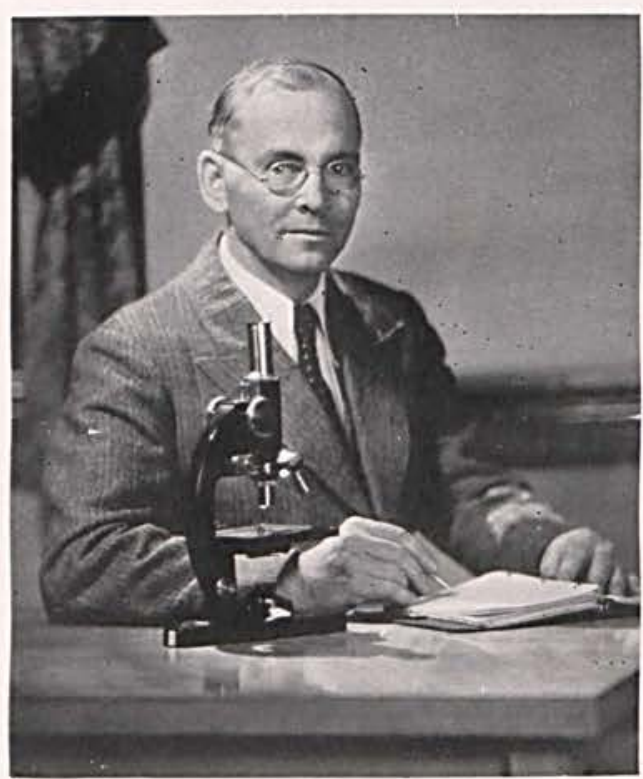

Prof. A. J. Hostetler, M. A.,

Director of Normal Department

Page Eighteen
Prof. D. R. Guthrie,

Religion
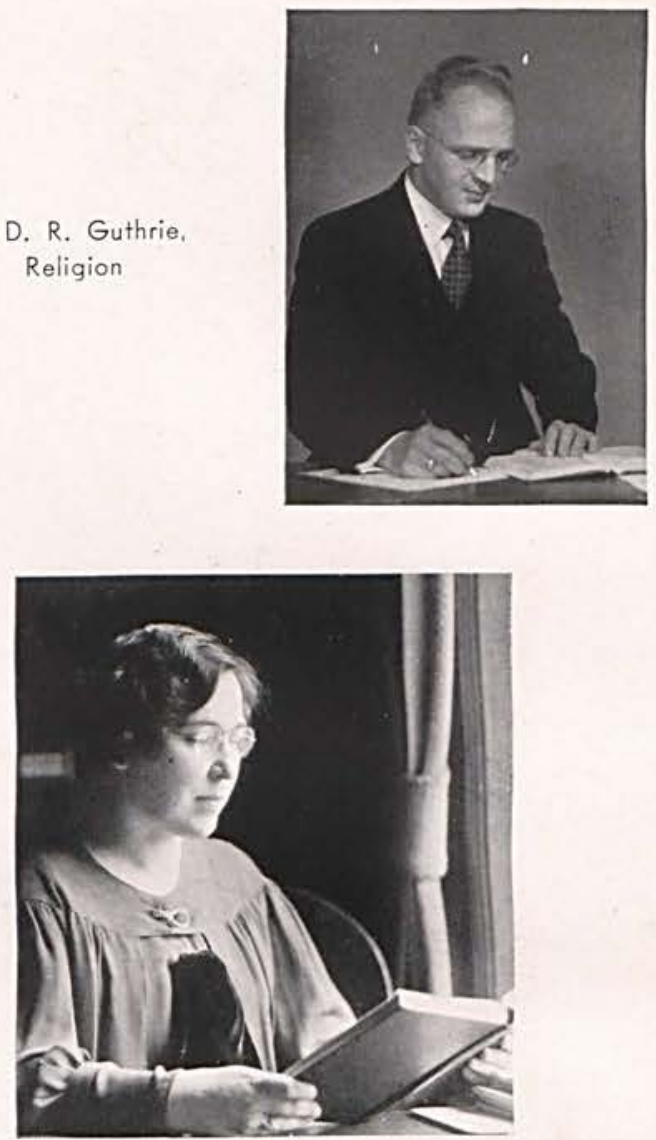

Prof. Louise T. Heintz.

English and Latin

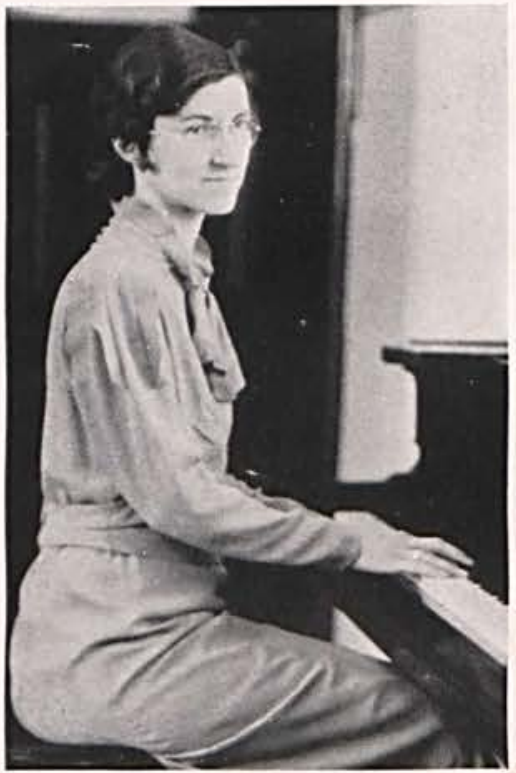

Prof. M. J. Work, M. M.

Director of Music Department 


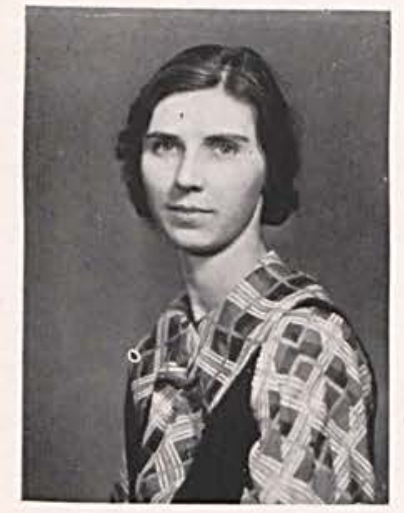

Miss Glenna Basore,

Instructor in Public Speaking

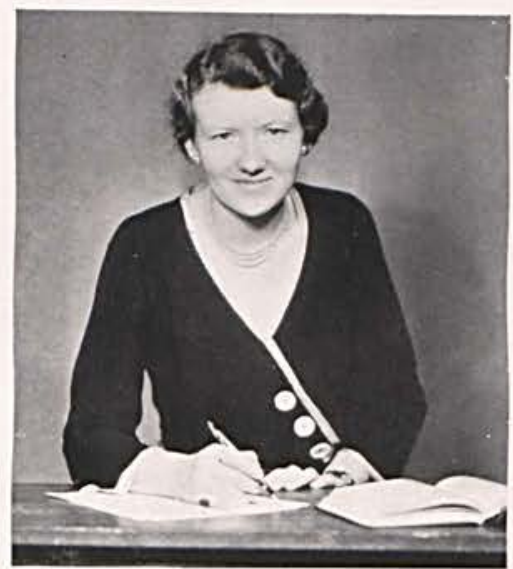

Mrs. Helen I. Jacobs,

Department of Education

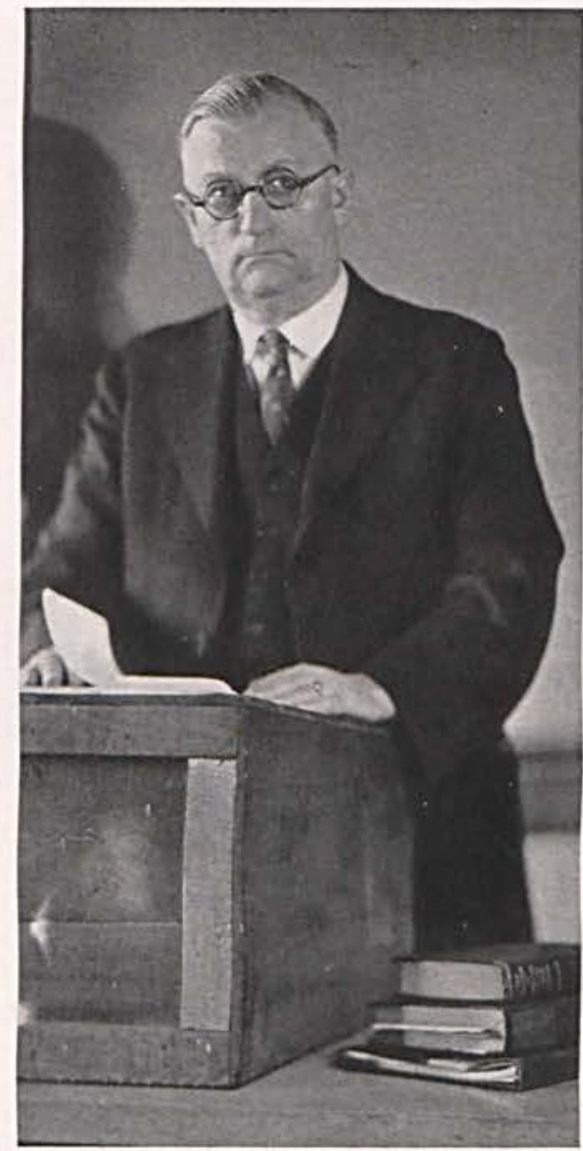

Prof. C. W. Steele, M. A.

Social Sciences and Public Speaking

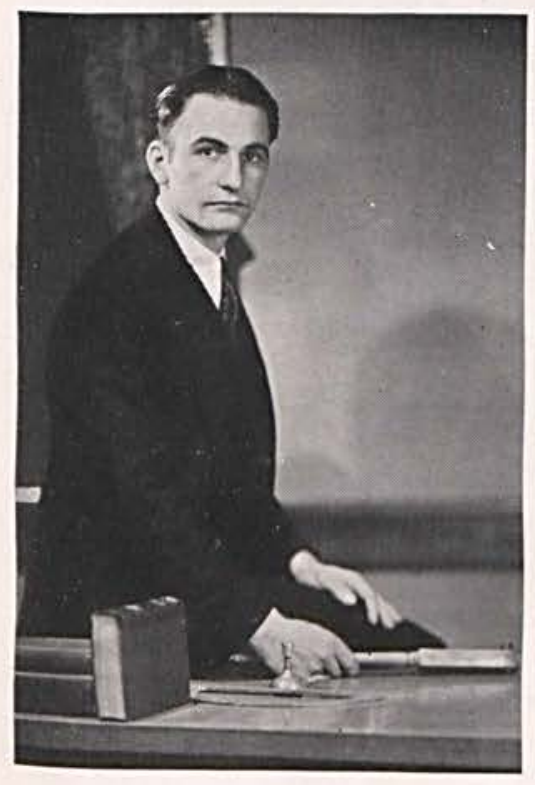

Prof. J. W. Ault.

Mathematics and Physical Education

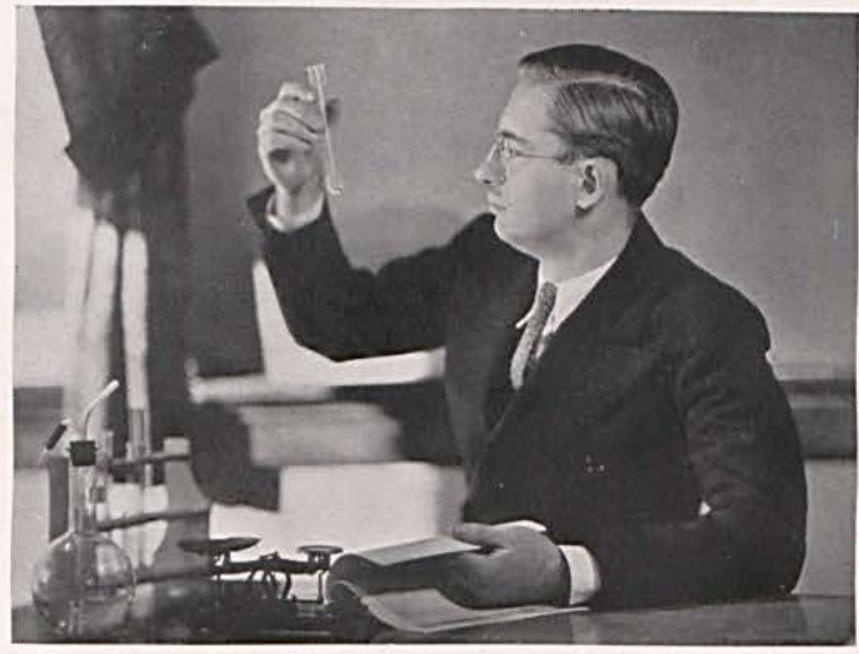

Prof. O. W. Kuehrmann,

Director of Science Department 

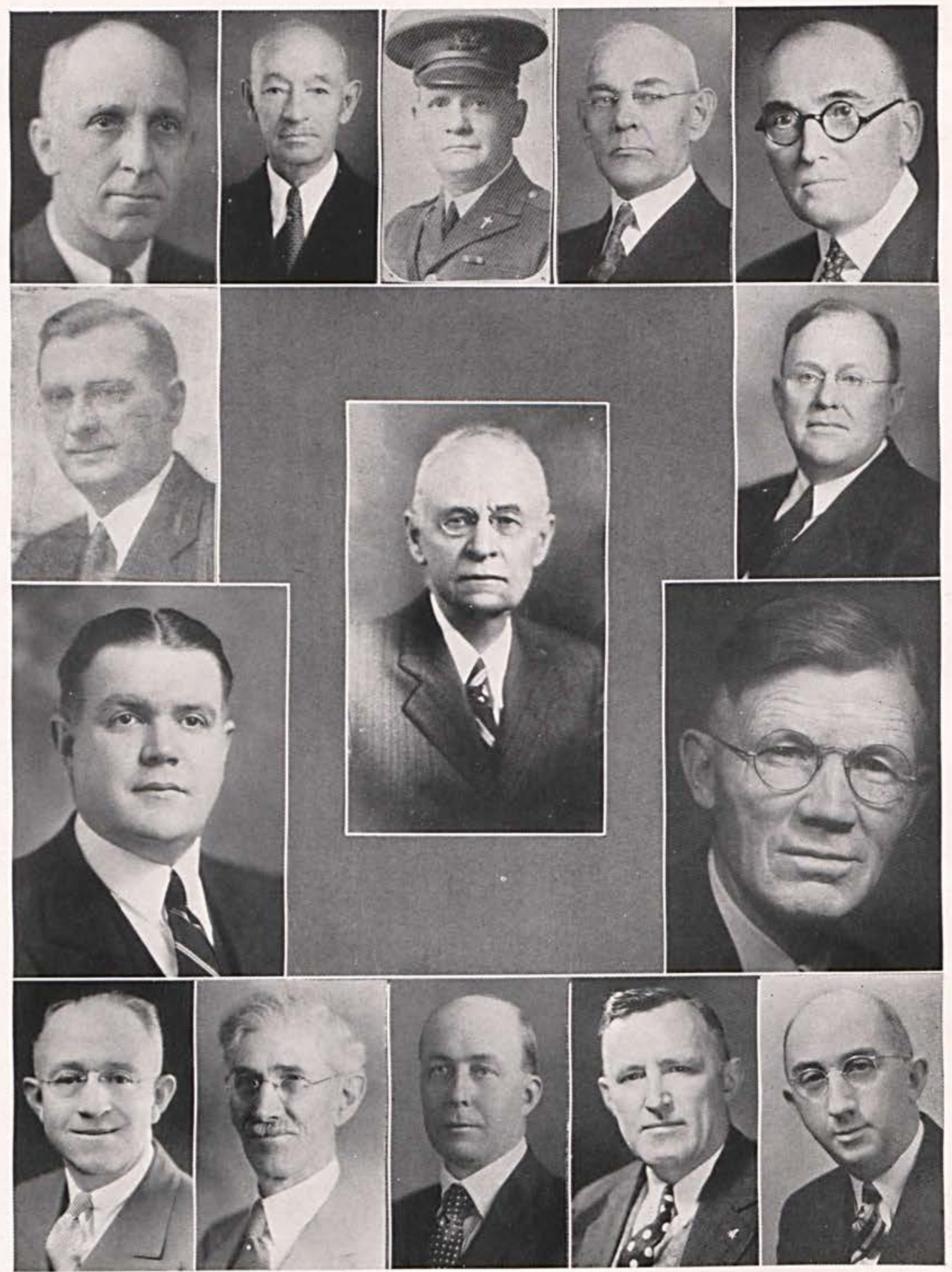

BOARD OF TRUSTEES OF CEDARVILLE COLLEGE

Bottom Row: J. L. Confarr, M. I. Marsh, M.D., Karlh Bull, G. H. Hartman, R. W. Ustick, D.D. Second Row: J. L. Chestnut, D.D., W. C. Iliff. Center: David McKinney, D.D., deceased. Third Row: W. C. Howard, D.D., W. H. Tilford, D.D. Top Row: W. R. Graham, D.D., William Conley, F. N. McMillan, D.D., Judge S. C. Wright, W. P. Harriman, D.D. 


\section{SENIOR CLASS HISTORY}

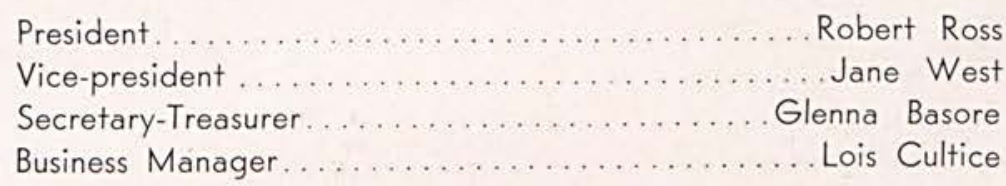

In the fall of 1930 the usual crop of youngsters arrived at Cedarville College with the usual amount of Freshman audacity and ignorance. From the first we proved to be an unusual class. We got off to a flying start by being the only freshman class in the history of the college whose feeds all escaped the ravages of the upper-classmen. Another unusual feature to which some attributed our success at keeping secrets was our notable lack of girls. But this handicap has been bravely overcome, as each year has marked an addition of female members to our class.

Our class is marked by high scholarship, as almost half of the students are members of the Cedarville College Crown Club. We have contributed more than our share to the various activities of the campus - in athletics, Y. W. and Y. M., music organizations, Literary Society, Debate team, etc. Perhaps two of our members should be mentioned in particular. Miss Glenna Basore has served as a most efficient and willing teacher of Oratory, and director of all the plays during her attendance at college. Miss Ruth West deserves special mention since she has attended college while employed in the Probate Court Office, but she has completed a full college course with high honors in addition to her regular position.

Our students come from three states, and a number have entered from time to time from other colleges. All these people have been welcome additions to our ranks.

\section{SENIOR PRESIDENTS OF THE PAST}
1903-J. Wilson
1904 - C. Rife
$1906-J$. Finney
1910-J. Williamson
1915-C. Ross
1916-D. Bradfute
$1918-W$. Collins
1920-M. Creswell
1922-J. Randall
1923-E. Collins
1924-D. Wickerham
1925-L. Markle
1926- H. Meyers
1927-R. Turnbull
1928-C. Weimer
1929-M. Chandler
1930-D. Marshall
1931-J. Stormont
1932-E. Irons
1933 -J. Free
1934-R. Ross 


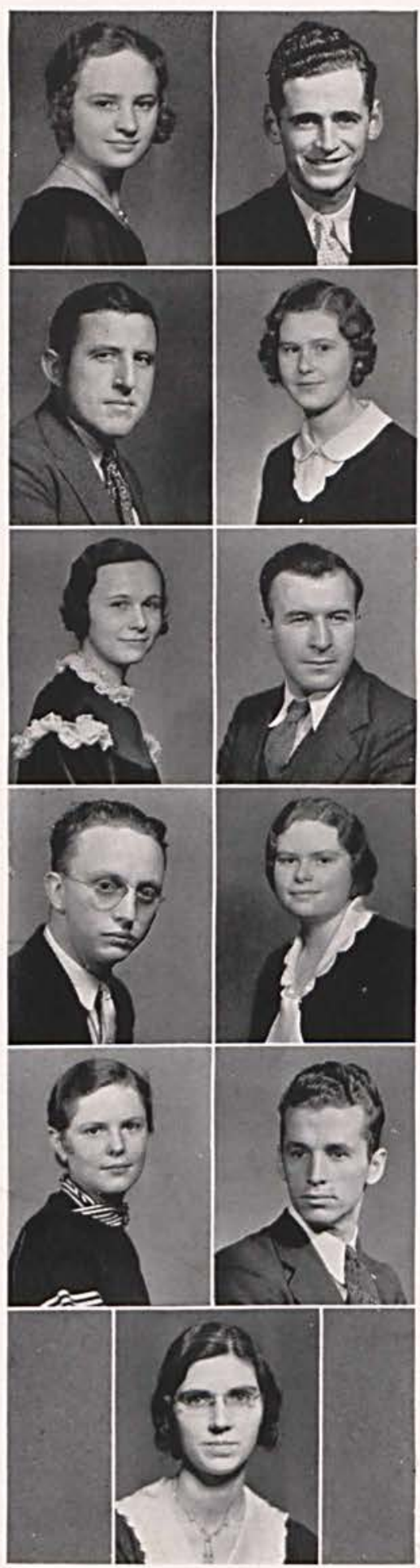

MARGARET BERK

B. S. in Education

Dayton, Ohio

Dayton Junior Teachers' College I, 2; Y. W. C. A. 3, 4; Literary Society 3: Mock Wedding 4: Class Play 3, 4; Glee Club 3, 4

\section{LLOYAL ROSS}

B. S. in Education

Bowersville, Ohio Wilmington College i, 2; Y. M. C. A. 3, 4; Class Play 4; Minstrel 4

GEORGE KENFIELD

A. B.

Woodstock, Ohio

Y. M. C. A. 3, 4; Football I, 2, 3: Class Play 4

LOIS CULTICE

A. B.

Springfield, Ohio, R. 5

Y. W. C. A. I, 2, 3, 4, Officer 2, 3, 4: Literary Society 3, 4, Officer 3: Class Officer 1, 4; Crown Club 3; Girls' Council 3: Mock Wedding I, 2, 3, 4, Bride 4: Class Play 3, 4; Cedrus Play 3, 4; Glee Club 1, 2, 3, 4; Mixed Chorus 3, 4: Cedrus Staff 3, 4

NINA STEVENSON

\section{A. B.}

Cedarville, Ohio

Y. W. C. A. 1, 2, 3, 4, Officer 3, 4: Literary Society 1, 2, 4; Class Officer 3: Instructor in Spanish 4: Basketball I, 2: Class Play 3, 4; Cedrus Play 3: Glee Club 1, 2, 3, 4: Quartet 1, 3, 4; Cedrus Staff 2, 3; Mock Wedding 1, 2, 3, 4

JOHN N. MURRAY

A. B.

Graniteville, Vermont Y. M. C. A 3, 4: Literary Society 1, 2, Officer 2: Class President 2: Instructor in Greek 4; Football 1, 2; Baseball I. 2, 3, 4; Minstrel 2; Class Play 4; Whispering Cedars Staff 4: Steward of Eating Club 2: Cedrus Staff 4

KENNETH FERRYMAN

B. S. in Education

Cedarville, Ohio

Y. M. C. A. 1, 2, 4; Literary Society 4; Minstrel 4; Class Play 4: Mixed Chorus 2, 4: Cedar Day Committee 2, 4 RUTH WEST

$$
\text { A. B. }
$$

Cedarville, Ohio Y. W. C. A. I, 2, 3, 4; Literary Society 1, 2, 3, 4: Crown Club 3: Mock Wedding 4: Class Play 3, 4: May Queen Attendant 4; Mixed Chorus 3, 4; Employed in Green County Probate Court 1, 2, 3, 4

JANE WEST

Y. W. C. A. 1, 2, 4, Officer 2, President 4: Literary Society

Cedarville, Ohio 1. 2, 4, Officer 4: Class Officer 1, 4: Crown Club 4: Office Assistant 1, 2, 4: Debate 4; Bible Reading Winner 1, 4; Mock Wedding 2, 4: Class Play 2, 4: Cedrus Play 2, 4: Glee Club 1, 2, 4: Mixed Chorus 2, 4: Cedrus Staff 2, 4 ROBERT ROSS

Bowersville, Ohio B. $S$. in Education

Miami University, Wilmington College, Ohio Northern University: Y. M. C. A. 3, 4: Class President 4: Instructor in Physical Education 4: Football 3; Basketball 3, 4: Baseball 3. 4: Class Play 3, 4; Cedrus Play 4; Cedrus Staff 4

\section{GLENNA BASORE}

$$
\text { A. B. }
$$

Carlisle, Ohio

Ohio Northern University: $\dot{Y}$. W. C. A. 2, 3, 4, Officer 3. 4; Literary Society 2; Class Officer 4; Crown Club 4; Instructor in Public Speaking 2, 3, 4; Play Director 2, 3, 4; Mock Wedding 2, 3, 4; Minister 4; Cedrus Staff 4 
Y. W. C. A. 1, 2, 4; Literary Society 1, 2, Officer 2; Crown Club 4; Debate 4: Bible Reading Winner 4; Mock Wedding I. 2, 4; Class Play 4; Glee Club I, 4

JOHN MILLS

Cedarville, Ohio A. B.

Y. M. C. A. I, 2, 3, 4; Class Officer 3; Football 1, 2, 3; Baseball 1, 2, 3, 4; Class Play 3, 4

HOMER MURRAY

Graniteville, Vermont

A. B.

Springfield College, Baypath Institute, Springfield, Mass. Student Body President 4: Y. M. C. A. 2, 3, 4, Officer 4; Literary Society 2, 3, 4, President 3, 4: Class President 3: Physical Education Instructor 4: Football 2, 3: Basketball I. 2, 3, 4; Baseball 2, 3, 4; Bible Reading Winner 4; Monks' Club, 4, Officer 4: Class Play 3, 4; Cedrus Play 2, 3: Minstrel 2: Cedar Day Committee 4; Cedrus Staff 2, 3, 4

DORIS HARTMAN

Cedarville, Ohio A. B. Y. W. C. A. 1, 2, 3, 4, Officer 2, 3, 4: Literary Society 1, 2, 3, 4, Officer 2, 3, 4; Class Officer 1, 2; Crown Club 3: Bible Reading Winner 1, 2, 3, 4: Mock Wedding 2, 3, 4: Class Play 3, 4; Cedrus Play 2, 4; Quartet 3, 4; Glee Club I, 2, 3, 4: Mixed Chorus 3, 4; Cedrus Staff 2, 4

DOROTHA CORRY Graduate in Piano

Cedarville, Ohio, R. 2

WALTER KILPATRICK

$$
\text { A. B. }
$$

Delaware, Ohio

Student Body Officer 4: Y. M. C. A. I, 2, 3, 4, President 4: State Council 3; Literary Society 1, 2, 3, 4, Officer I, 2, 3, 4: Crown Club 3: Class Officer 2: Debate 2, 3, 4: Tennis 12. 3, 4, President 2, 3; Bible Reading Winner 3, 4; Minstrel 2; Class Play 3, 4: Cedrus Play 3: Cedar Day Orator 4: Cedar Day Committee 4; Cedrus Staff 3, 4, Editor 4

GEORGE MOODY

Wittenberg College I, 2; Y. M. C. A. 3, 4

Springfield, Ohio VIRGINIA WATKINS

$$
\text { A. B. }
$$

Xenia, Ohio

Miami University, Miami-Jacobs Business College: Y. W. C. A. 2, 3, 4: Mock Wedding 4; Class Play 4: Cedar Day Attendant 4

\section{J. PAUL MCLAUGHLIN}

B. S. in Education

Salem: Illinois

S. I. N. U., Carbondale, III., Berea College; Y. M. C. A. 3, 4; Monks' Club 4, President 4; Class Play 4; Mixed Chorus 3, 4

\section{RAYMOND HARGRAVE}

B. $S$. in Education

Bowersville, Ohio

Wilmington College i, 2; Y. M. C. A. 3, 4: Football 3. Basketball 3, 4; Baseball 3, 4; Class Play 4

REGENA SMITH

$$
\text { A. B. }
$$

Cedarville, Ohio

Ohio State University: Y. W. C. A. 1, 2, 3, 4, Officer 4; Literary Society 1, 2, 3, 4; Class Officer 3: Crown Club 3: Student Council 4; Whispering Cedars Staff 4: Instructor in Physical Education 2, 3, 4: Student Body Officer 4: Basketball I, 2, 3, 4; Mock Wedding 1, 4; Cedar Day Committee 3, 4; Cedar Day Queen 4; Cedrus Staff 4
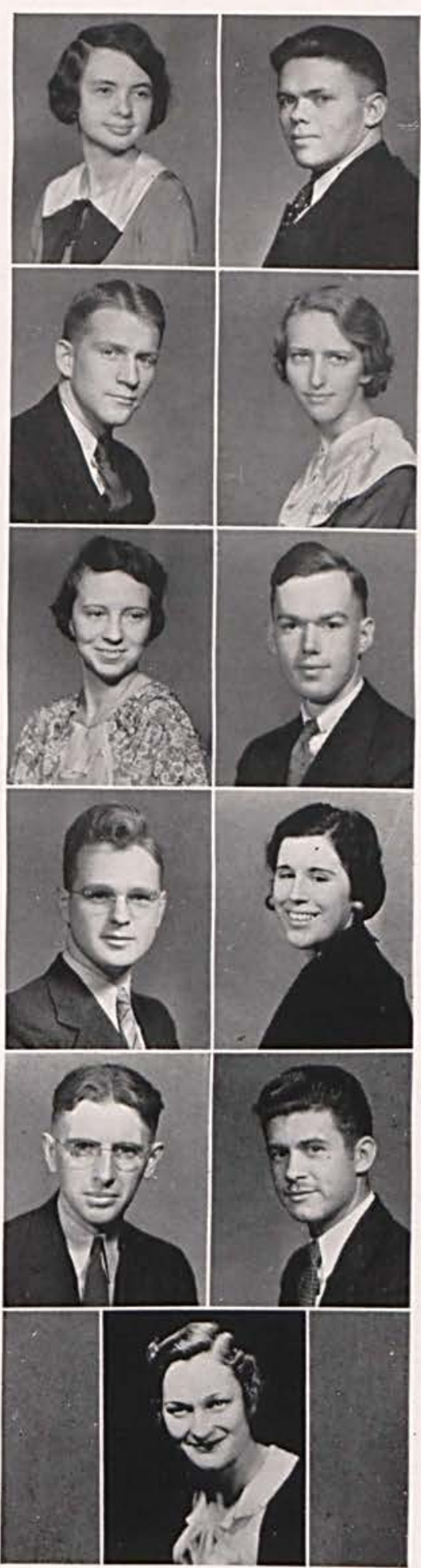


\section{JUNIOR HISTORY}

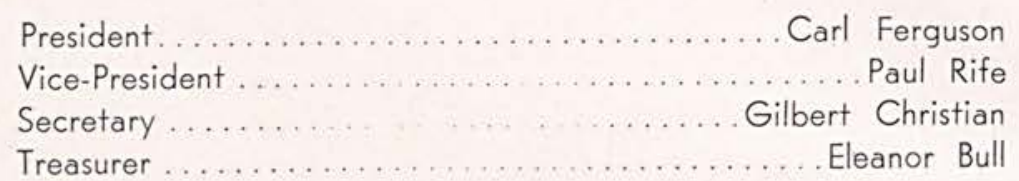

All aboard! The cry did not need to be sounded a second time for thirty-two new sailors that joined the ship of time in 1931 to traverse the choppy waves of college life.

The weather prophets (professors) had prophesied clear sailing, but ere we had been on board a few weeks, the waves beat high and the new sailors strove hard for a whole week to keep the boat upright (and their dignity), only to be upset at the famous whirlpool (Willow Bend).

With "Bob" Harriman on the bridge of the ship to choose the best course, we each took our boats to answer the S. O. S. call of the football, basketball, baseball, and tennis crews, as well as chorus, glee club, literary society and other organizations that were strengthened by the "Freshies".

Answering the call for 1932-1933 there were twenty-six in our crew with "Art" Donaldson in the pilot-house. This year after a struggle we survived the whirlpool, but the Freshmen weren't so lucky.

Again more of our boats went out to answer the S. O. S. calls of the football, basketball, baseball, tennis, and debate crews, as well as helping to rescue the chorus, glee club, and other organizations.

On Cedar Day we buried the Sophomore class and bid goodbye to five of our crew who were to become masters of a larger crew, as elementary teachers.

"Stew" Kitchen was chosen helmsman of the ship with crew of eighteen, as it started on the second half of the journey. Misfortune soon befell us and we lost "Stew", who left our ship to captain his own. At the end of the semester, "Bill" McCallister left our crew without a man in control, so we selected "Fergy" to lead us.

This year we continued to take our course through the choppy waves and join the different teams and organizations.

We made good at selling candy, which, with the proceeds from "Blarney Street", our class play, furnished the means to treat the Senior crew, May 10, at Lawrenceville.

We are hoping to sail successfully into harbor next year. 
GILBERT CHRISTIAN

MAXINE BENNETT

ARTHUR DONALDSON

WILLIAM WADDLE

ELEANOR BULL

ROBERT TAYLOR

\section{EUGENE SPENCER}

CAROLINE BRILL

JOSEPH FINNEY

PAUL RIFE

CARRIE MOUNT

CARL FERGUSON

RALPH TINDALL

DOROTHY LUNSFORD

ROBERT HARRIMAN

FRANKLIN TRUBEE

W. B. MCCALLISTER
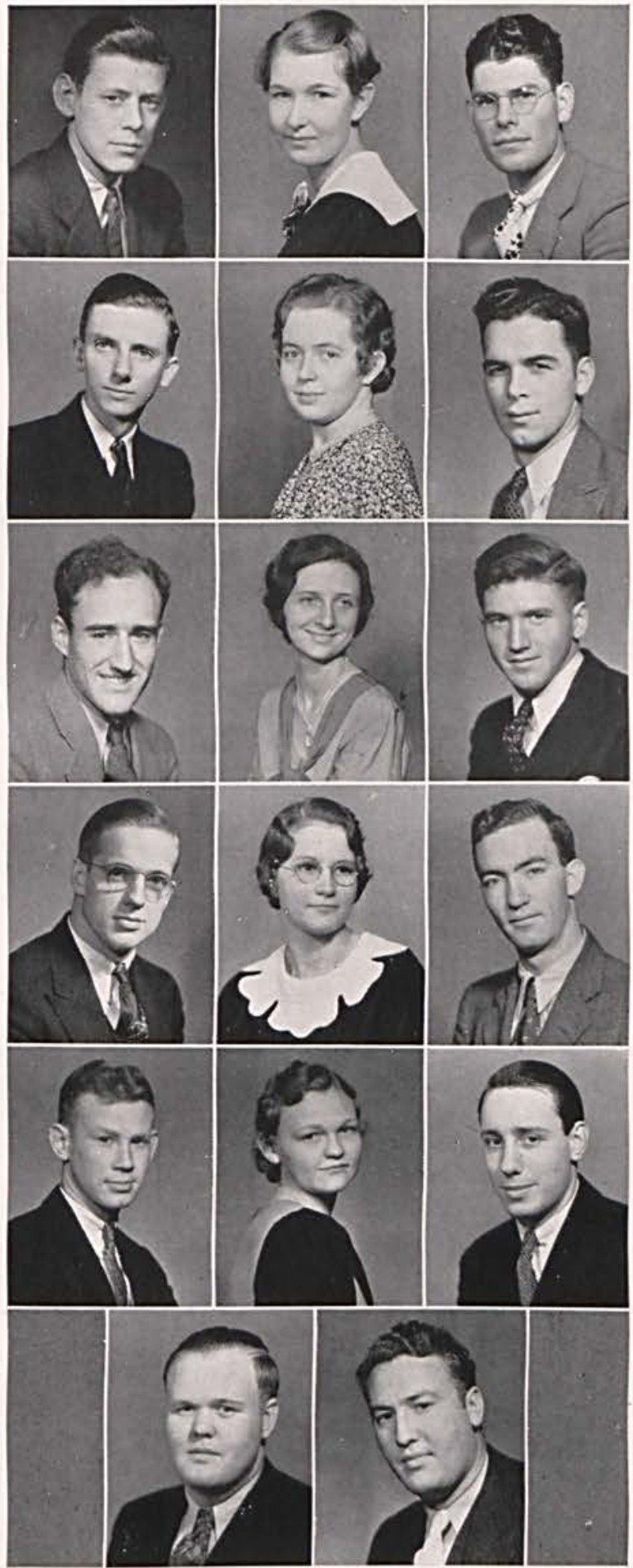


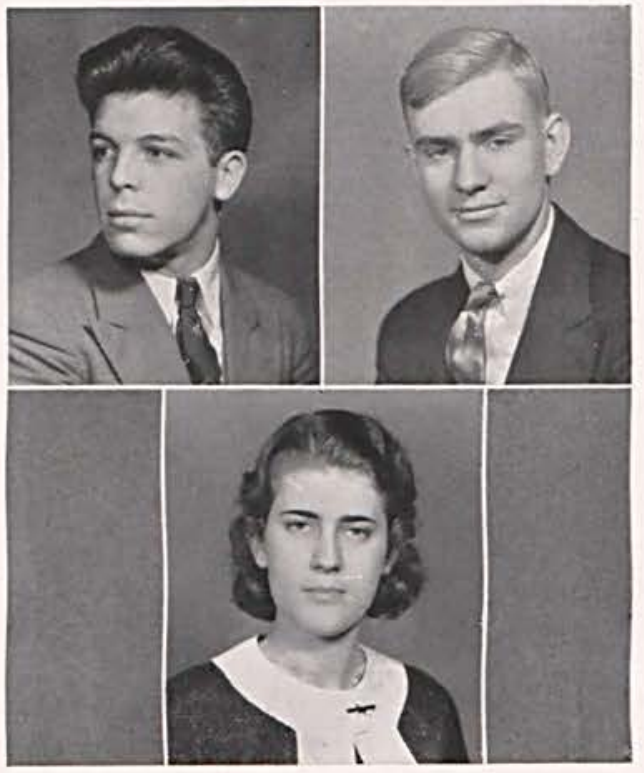

\section{SOPHOMORE HISTORY}

Errol Macknight, President: Charles Chamberlain, Vice-president; Wilma Chenoweth, Sec'y-Treas.

As the end of our second year at Cedarville College draws to a close, we look back to see what we have done and what has been done to us. We began our Freshman year with thirty-seven students. We went through all of the necessary initiation features as well as could be expected. As the year progressed we became more used to the routine of college work, doing our best in all we attempted. At the opening of our Sophomore year we found but twenty-five of our original class returning. We have continued through this year to take an active part in all college activities. At the end of this year we shall lose some more students, some finishing the two year normal work, while others advancing to the Senior class through summer school work.

First Row: Wham, Coulter, J. McCallister, Henry, Macknight, O. Brill, Hostetler, Labig, D. Corry. Second Row: Dean, Crager, Hine, L. Robe, Chenoweth, Bradley, M. McLaughlin, Burkert, Cappola, R. Murray. Third Row: Thompson, W. Linton, Meyers, Thomas, Buehler, Reed, Ensign.

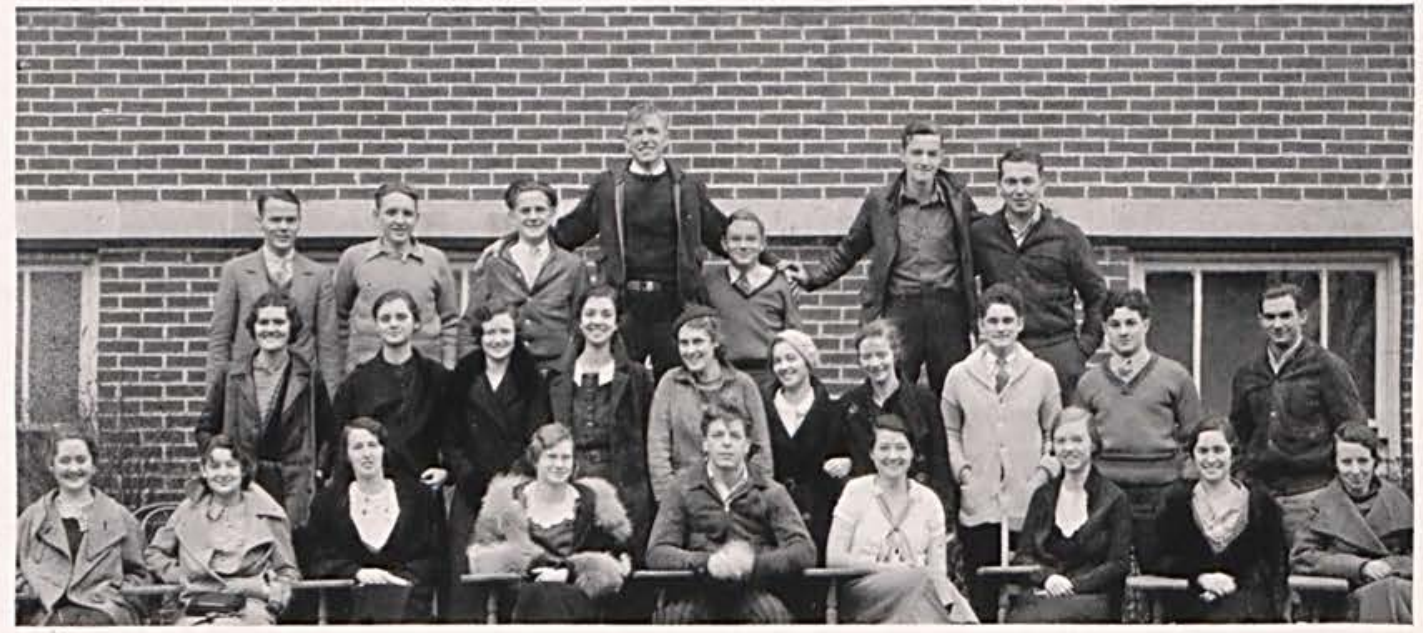




\section{FRESHMAN HISTORY}

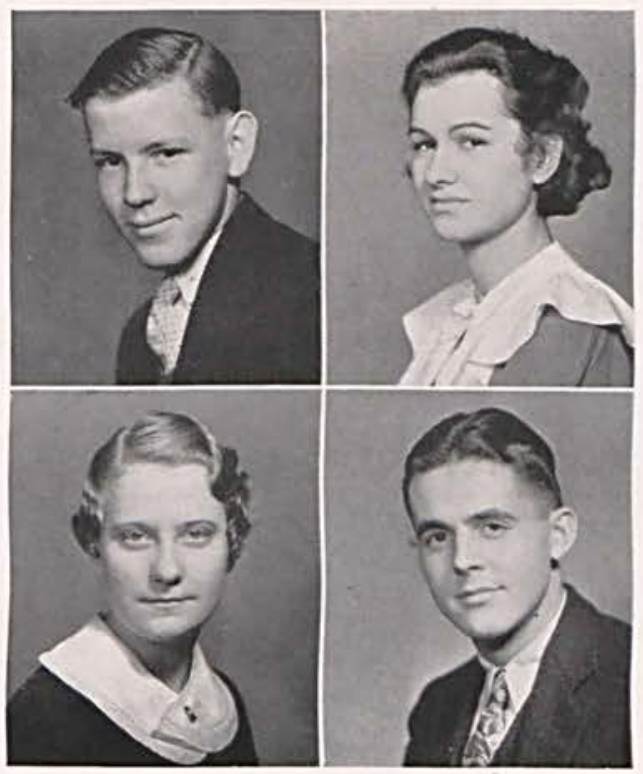

John Richards, President; Dorothy Anderson, Secretary; Glenna Ackerman, Treasurer; Donald Trout, Vice-president.

In the fall a large class of bewildered Freshmen entered college. To lead them through the hardships of that first year they elected John Richards, President; Donald Trout, Vice President; Dorothy Anderson, Secretary, and Glenna Ackerman. Treasurer. After the week of hazing, climaxed by the Freshmen triumph at the annual tug-of-war, was over, the class began to take an active part in college life. Their contributions to the various organizations have been: to basketball, Swaim, Harris, Waddle, Wallace; to baseball, Harris, Waddle, Ackerman; to tennis, Swaim, Corry, Wallace; to the male quartet, Trout, Richards, Corry; to debate, West; to the Orange and Blue Serenaders, Ritenour. Anderson, Skinnell; to the Gospel Team, Gordon, Angell, Grube. Several very successful Freshmen feeds have been enjoyed by the class-in fact, by the entire college. And with this record the class of ' 37 has taken its place in the life of Cedarville College.

First Row: Hoke, Beard, May, E. Robe, G. Ackerman, Ritenour, Kimble, E. Waddle, B. Miller. Second Row: Wallace, O. Ackerman, Swaim, Harris, Gordon, E. Corry, Collett, Cross, Anderson, Skinnell, Fisher, Foster, Creswell, Brock, Laybourne, Richards, Grube, Tobin. Third Row: J. Waddle, W. Hartman, Trout, Potee, Tobias, R. Bull, Dobbins, Geer, Angell, Gray, Ross, Sullivan, J. West.

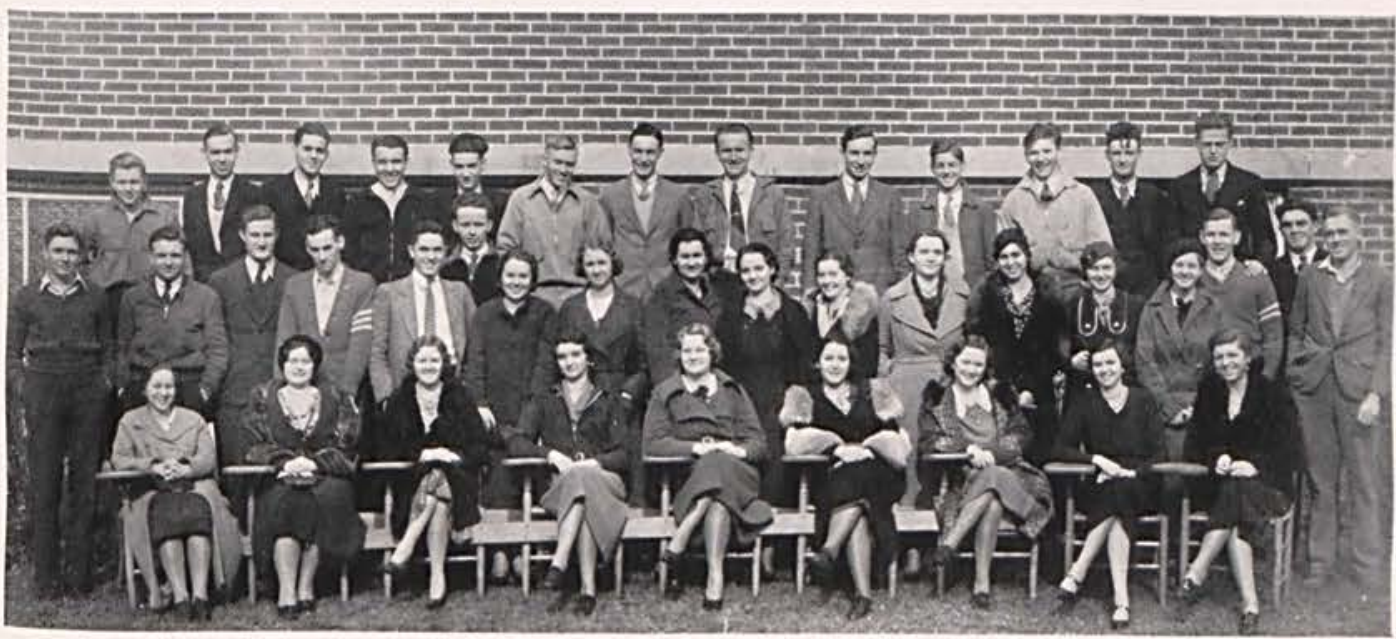



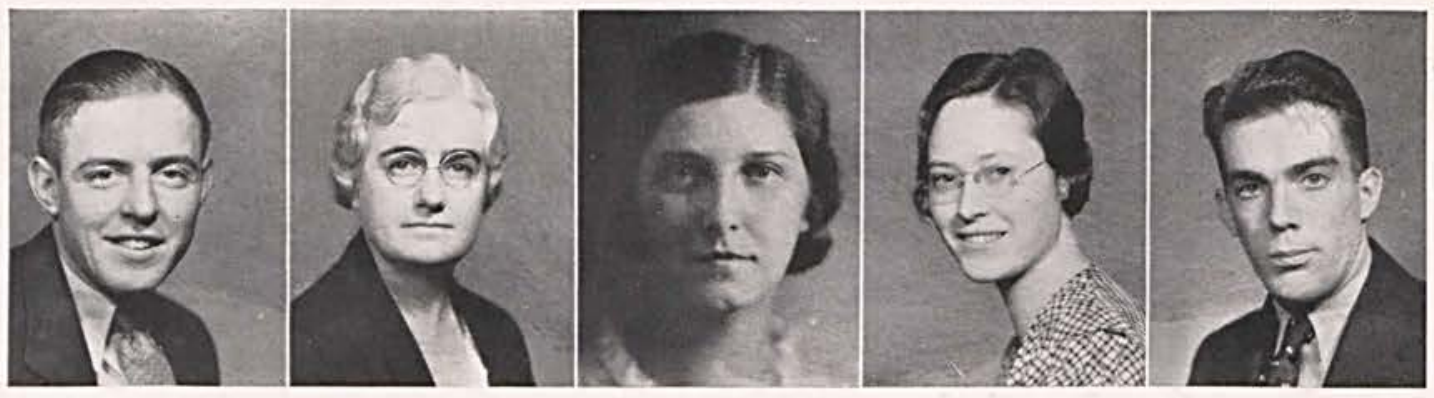

Turner, Hill, Wheeler, Tanner, Gormley

\section{SPECIAL STUDENTS}

This year we are glad to have in addition to our regular student body, several special students. Four of them are graduates of Cedarville College, three of whom have returned, after some teaching experience, to add to their work. The others are taking part-time work in special fields.

\section{PRACTICE TEACHERS}

Cedarville College has sent many efficient graduates into the worlds of industry, ministry, and service, but she is best known for the excellent teachers which she sends forth. Much of this success is due to the earnest and continued efforts of Professor Hostetler, the advisor of the embryo teachers. Professor Hostetler is a willing helper, a truthful and untiring advisor, and a friend at all times.

This past year he has been assisted in the normal department by Mrs. Helen Jacobs. who has directed the training for elementary teaching.

First Row: Smith, Crager, Cultice, Stevenson, H. Murray, Watkins, Coulter, R. Ross. Second Row: J. Murray, Henry, J. McCallister, Basore, Pyles, D. Hartnan, J. West, Thomas, Ferryman, Macknight, Lunsford. Hargrave.

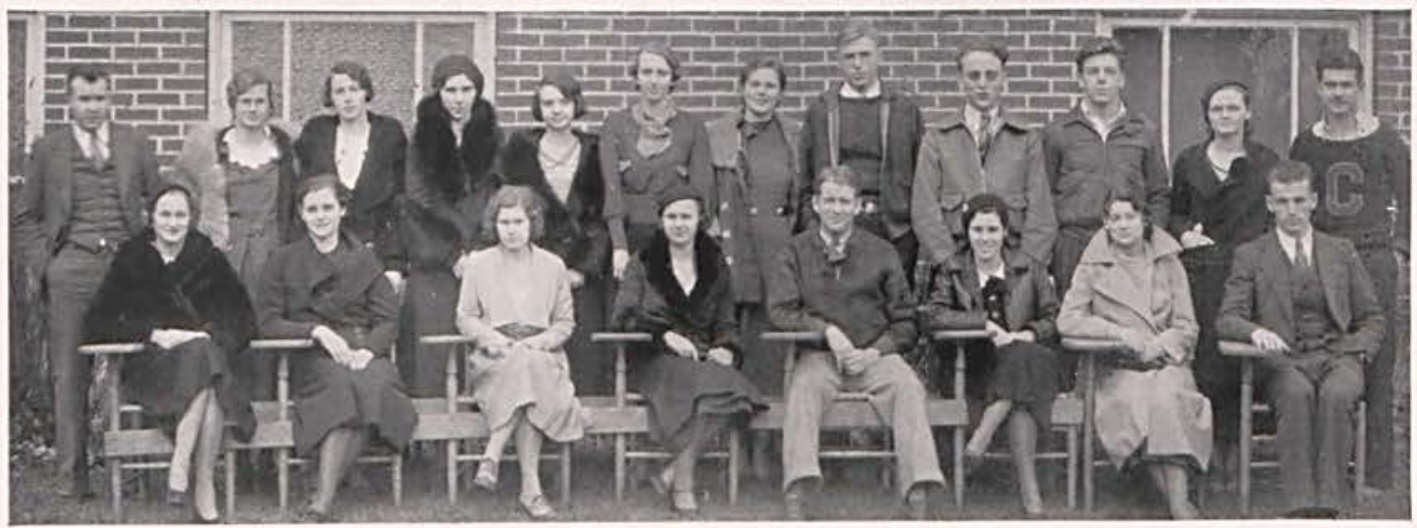

Page Twenty-eight 

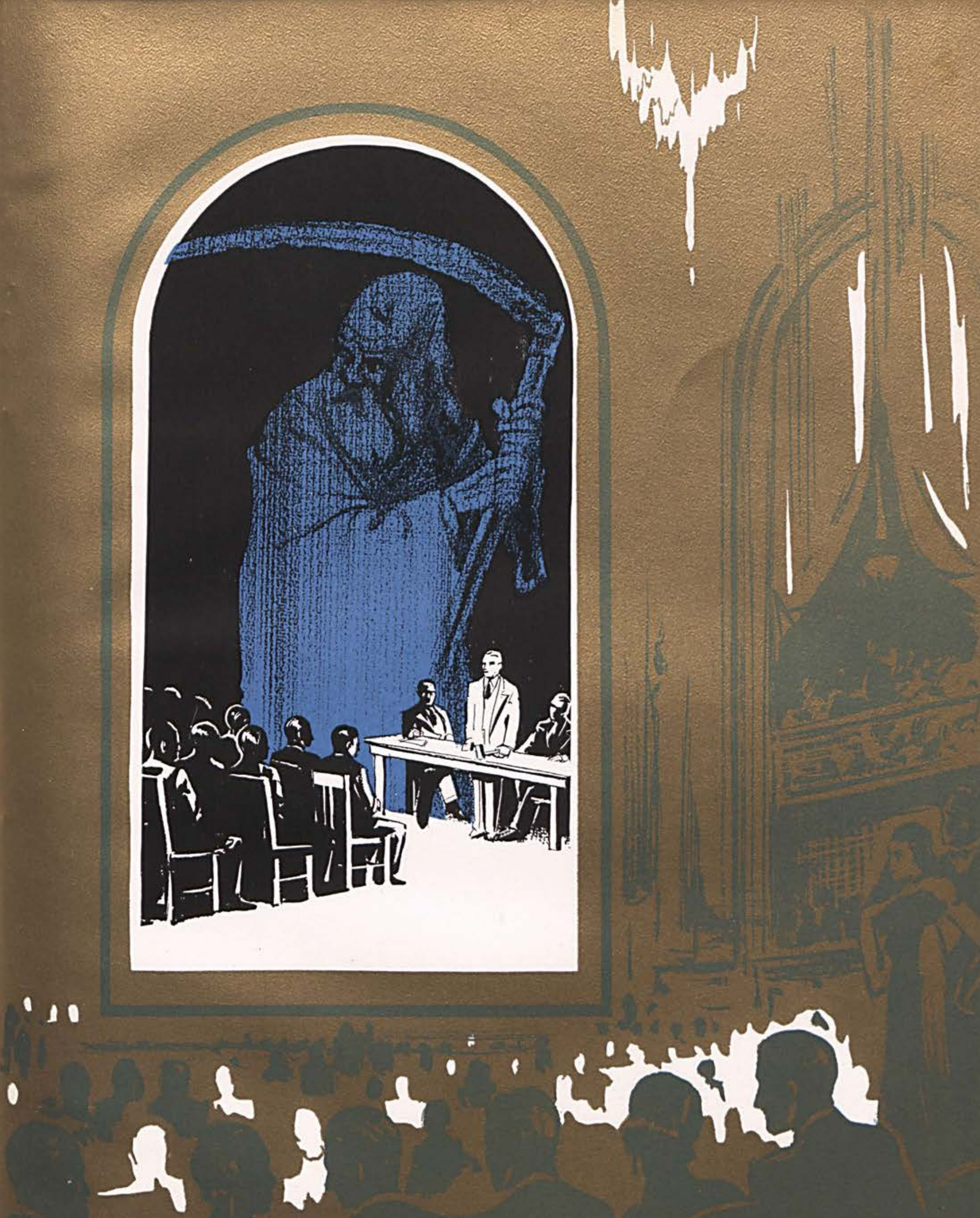

\section{ACT TWO . ORGANIZATIONS}





\section{ORGANIZATIONS, 1894-1934}

STUDENT AND ALUMNI ADMINISTRATION

Alumni Association founded 1897

Student Council founded 1933

Girls' Student Council.

LITERARY AND DRAMATIC

Philadelphian Literary Society .......................... founded 1894

Philosophic Literary Society.............................. founded 1895

Dramatic Club ........................................ founded 1896

Gavel Club................................... founded 1906

Gavelyte Staff.

Memorabilia Staff.

Imago Staff.

Oratorical Association:

Orange and Blue Literary Society.................... founded 1915

Cedrus Staff ..................................... founded 1915

Varsity Debate.

Cedar Needles Staff.

Whispering Cedars Staff.......................... founded 1933

\section{RELIGIOUS}

Y. M. C. A.

founded 1907

Y. W. C. A

Monks' Club

MUSICAL

Mandolin and Glee Club.

founded 1896

Glee Club.

College Orchestra.

Revelers' Quartet.

Cedar Needles' Quartet.

Orange and Blue Serenaders' Quartet.

Neapolitan Knights' Quartet.

Mixed Chorus.

\section{MISCELLANEOUS}

Women's Advisory Board.

A. O. E.

S. M. C.

Tennis Club.

Masticating Club.

Boarding Club.

Fraternity.

$X$ Club 


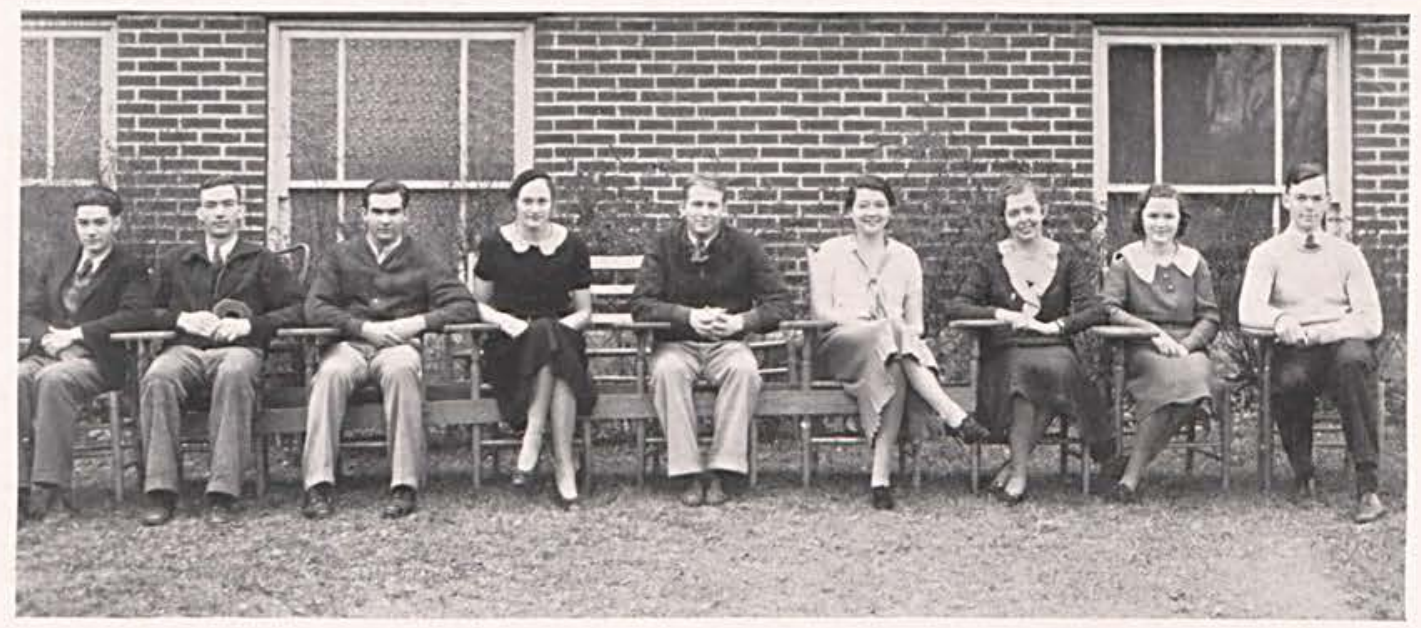

Tobias, Ferguson, R. Murray, Smith, H. Murray, O. Brill, E. Bull, Kimble, Kilpatrick.

\section{STUDENT COUNCIL-1933-1934}

The Student Council was active throughout the current year. The officers were Homer Murray, President; Walter Kilpatrick, Vice-President; Regena Smith, SecretaryTreasurer.

\section{STUDENT BODY PRESIDENTS} OF THE PAST

1923-E. Collins

1926- H. Meyers

$1927-F$. Wills

1928-D. Kennedy

1929-J. Beam

1930-P. Tanner

$1931-R$. Collins

1932-E. Irons

1933-R. Richards

$1934-$ H. Murray
The outstanding accomplishment of the year was the organization of a new school publication called "The Whispering Cedars". This bi-weekly news magazine was welcomed by each member of the student body as a means of "cussing and discussing" many interesting phases of our college life.

The organization of a Student Council, to cooperate with the faculty in various matters, was another bright spot in the work of the year.

Both the school paper and the formal organization of a Student Council were first proposed at a joint meeting of the Y. M. and Y. W. C. A. cabinets early in the fall, and each project fills a long-needed place in Cedarville College life.

Cooperation is one of the essential features of any successful enterprise. The student body cooperated in a helpful manner, and much of the success of our Student Council of 1933-34 is due to this element. 


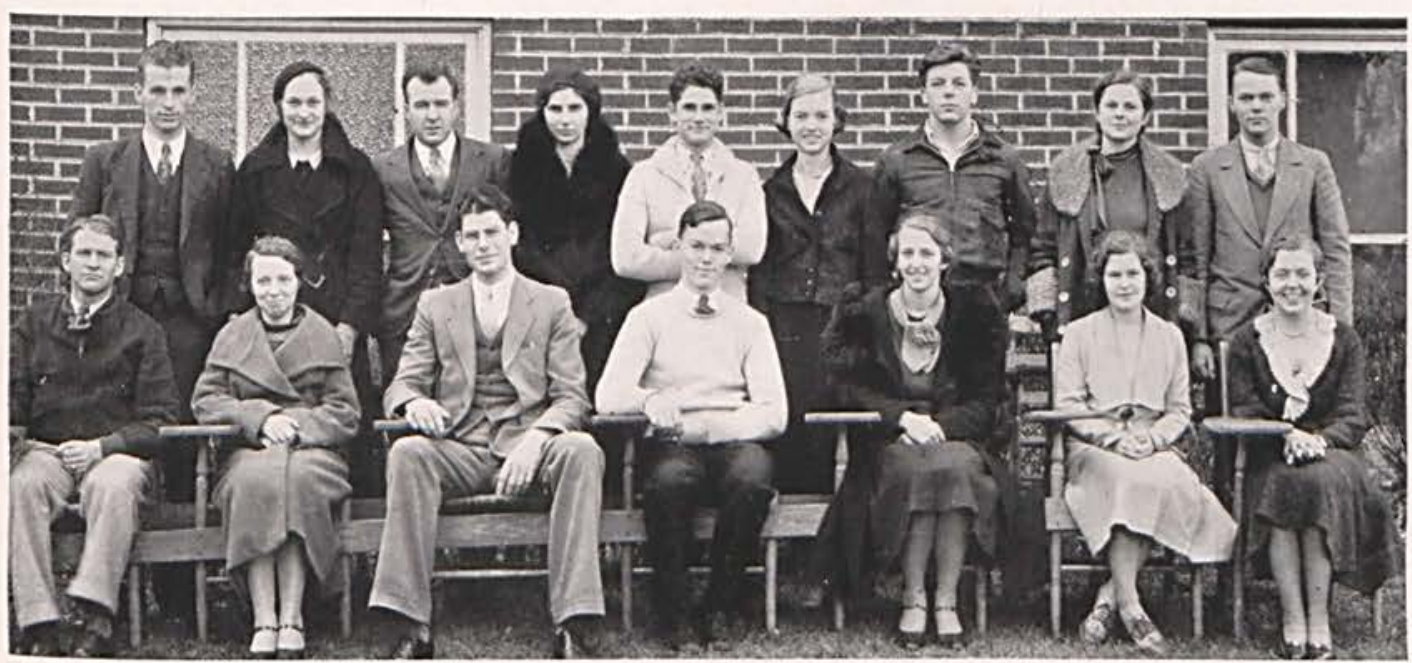

First Row: H. Murray, D. Corry, Donaldson, Kilpatrick, D. Hartman, Cultice, E. Bull. Second Row: R. Ross, Smith, J. Murray, Basore, Burkert, C. Hostetler, Macknight, J. West, Thompson.

\section{CEDRUS STAFF}

Growth is perhaps the most interesting thing in the world to watch. As the pictures have been taken, the contracts awarded, the write-ups brought in, and the other features which make up a college annual have been completed, the members of the staff have become increasingly interested in watching the 1934 Cedrus grow to its present form. The countless details of annual construction have occasionally kept staff members working far into the wee small hours, but no one regrets the time and effort spent, for the experience has been valuable and engrossing.

While the elected Cedrus staff, under the direction of the editor and business manager, and with the guidance of the faculty advisor, has been responsible for the actual publication of the book, it was only with the enthusiastic support of the other students, the alumni, the engravers, printers, binders, and photographer with whom we worked, and the business men and good friends of the College everywhere, that we have been able to complete our task.

Portrayal of the ideals and the spirit of Cedarville College's first forty years has been the staff's chief aim as it prepared this book for Cedarville's friends everywhere. If, on the sixtieth, seventieth, and eightieth anniversaries of the school, the reader can carry this then-worn volume to his favorite chair by the fire-place, and turn the pages with smiles of recognition and heart-throbs of memory alike, we will feel that we have fulfilled our trust.

\section{CEDRUS EDITORS OF THE} PAST

1915-R. Elder

1916-M. Rife

1917-F. Summers

1918-S. Liming

1919-J. Rickenbach

1920-E. Tarbox and M. Creswell

$1921-\mathrm{H}$. Hammond

1922-E. Bradfute

1923-M. McClellan

1924-M. Stormont

1925-L. Markle

1926-H. Meyers

1927-M. McKay

1928-M. Webster

1929-C. Frazier

1930-D. Marshall

1931-W. Boyer

1932-G. Martin

1933-C. Hutchison

1934-W. Kilpatrick 


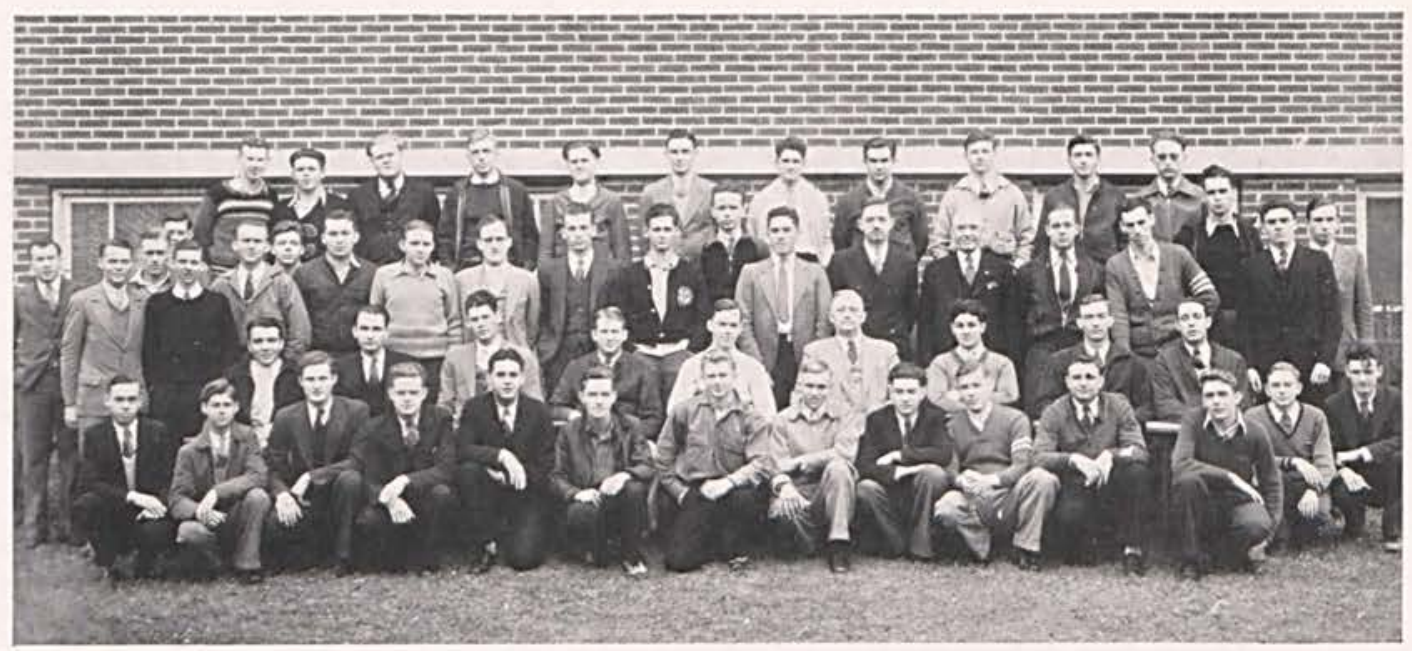

First Row: W. Hartman, Gray, Swaim, J. West, Trout, Reed, J. Waddle, R. Bull, Tobias, Richards, 0. Ackerman, Thompson. Second Row: W. Waddle, Potee, Ault, Donaldson, H. Murray, Kilpatrick, Steele, Cappola, Ferguson, Harriman, Buehler, Sullivan. Third Row: J. Murray, Thompson, Tobin, Christian, Geer, Macknight, Ensign, Linton, Spencer, R. Ross, L. Ross, E. Corry, Gordon, Kuehrmann, McChesney, Rife, Harris, Taylor, Grube, Angell. Fourth Row: Tindall, Mills, Trubee, Thomas, Meyers, Dobbins, Burkert, R. Murray, G. Ross, Finney, Ferryman.

Y. M. C. A.

Eleven-twenty o'clock Wednesday morning usually found most of the young men in college in attendance at the Young Men's Christian Association meeting. Through the able efforts of program chairman, Carl Ferguson, and his committee, many interesting programs and speakers were presented. The inspiring lectures and entertaining speeches given by Professor Booker of Wilberforce, Dr. J. Harry Cotton of Columbus, "Bob" French of Clifton, Rev. Mr. Hartman of Osborne, and Y. M. State Student Secretary, Ralph Garner, will not soon be forgotten. During the course of the year several joint meetings were held with the Y. W. C. A.; also programs were exchanged with the Wilmington $Y$. M. C. A. In addition, the organization at various times heard talks by members of the faculty and local ministers as well as by members of our own student body.

The $Y$ took an active part in promoting plans for the increased enjoyment of school life, and can point to several notable accomplishments, and a state-wide reputation as a live-wire organization.

1922-E. Bradfute

1923-D. Wickerham

1924-W. Snell

1925-F. Wills

1926 - C. Shanks

1927-W. Creswell

1928-D. Kennedy

1929-C. Frazier

1930-B. Turner

1931-V. Hickman

1932-M. Hostetler

1933-P. Garlough

1934-W. Kilpatrick

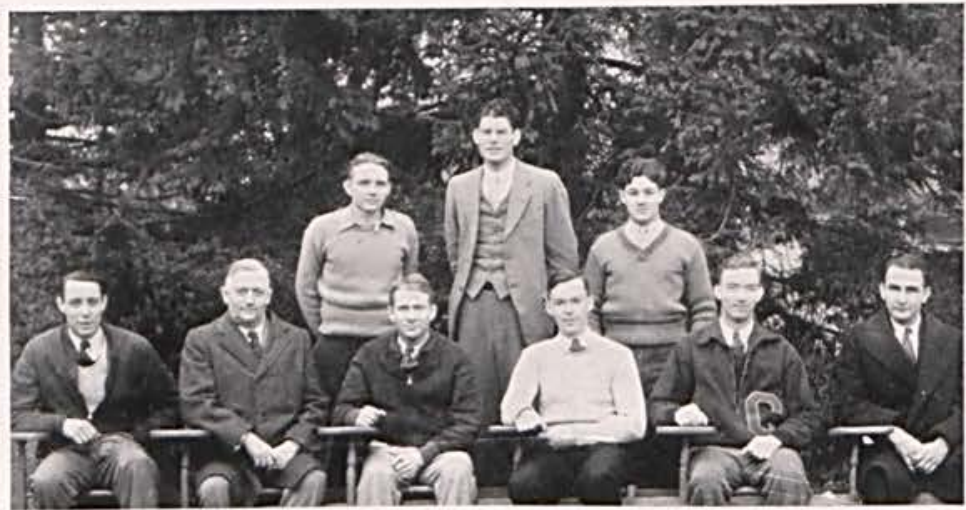

Harriman, Program Committee; Steele, Adviser: H. Murray, Vice-president: Kilpatrick. President; Ferguson, Program Chairman: Ault. Adviser; Linton, Social Chairman; Donaldson, Program Committee: Cappola,

Publicity Chairman.

Page Thirty-four 


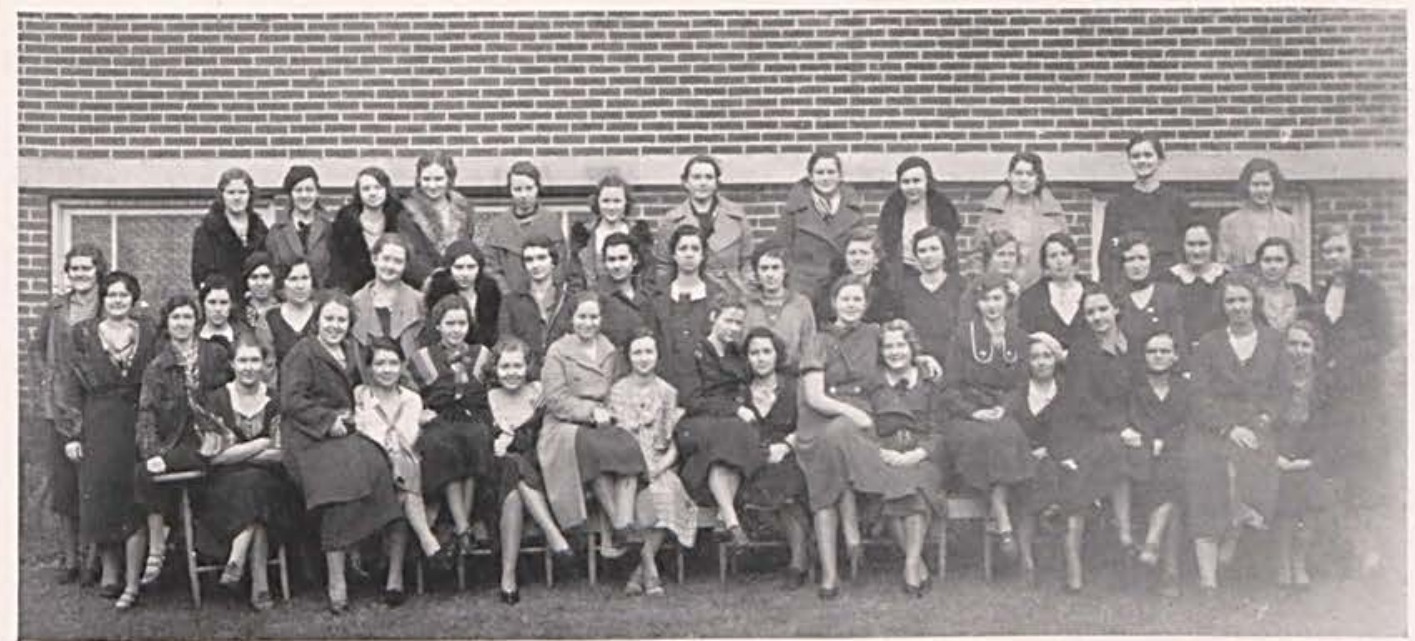

First Row: Work, Bennett, Collett, O. Brill, Fisher, E. Bull, Hoke, C. Brill, M. McLaughlin, Ritenour, J. West, G. Ackerman, Brock, Bradley, Skinnell, Lunsford, Cross, D. Hartman. Second Row: Dean, Beard, Watkins, Creswell, Heintz, Wham, Basore, E. Robe, Anderson, L. Robe, Chenoweth, Miller, E. Waddle, Henry, J. McCallister, Hine, Smith, Labig, Hostetler. Third Row: May, Laybourne, Pyles, Berk, D. Corry, Kimble, Foster, Mount, Stevenson, Coulter, Crager, Cultice.

\section{Y. W. C. A.}

The Young Women's Christian Association is the one group on the campus in which every girl is interested, with all its activities built around the needs of its members.

This year almost every girl was a member of the Y. W. and the spirit of fellowship and cooperation which was manifested warmed the hearts and spirits of those responsible for the welfare of the organization.

When we leave Cedarville College we may forget many things which we have learned, but we will always treasure memories of $Y$. W. meetings and parties. The meetings were varied and each seemed to meet some need or desire of each person. The three phases of life to be developed, the physical, the mental, and the moral, were stressed in various ways.

From the Welcome Tea and the Committal service to the Mother-Daughter Banquet, we have enjoyed every minute of fellowship together.

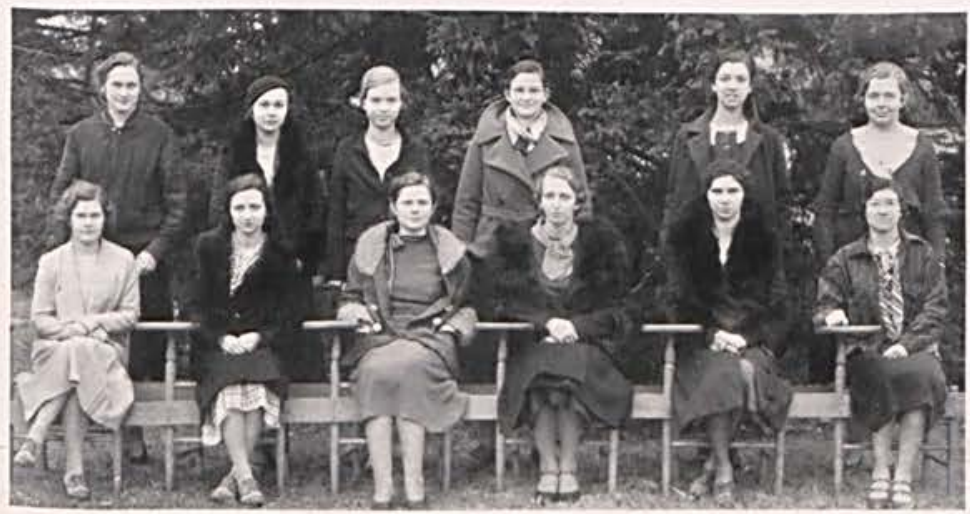

Y. W. PRESIDENTS OF THE PAST

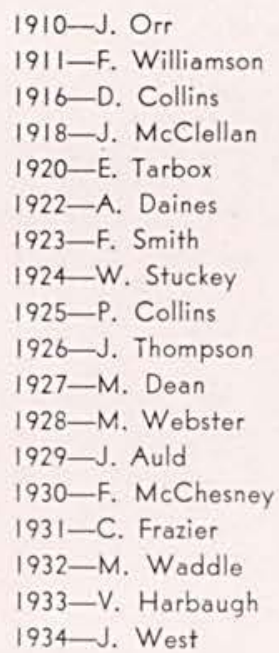

First Row: Cultice, Social Chairman: C. Brill, Secretary-Treasurer; J. West, President; D. Hartman, Vice-president; Basore, Program Chairman Mrs. Work, Adviser. Second Row: Smith. Social Service: Stevenson, Hostess: Hostetler, Publicity: Mount, Financial Chairman; L. Robe, World Fellowship: E. Bull, Miembership Chairman. 


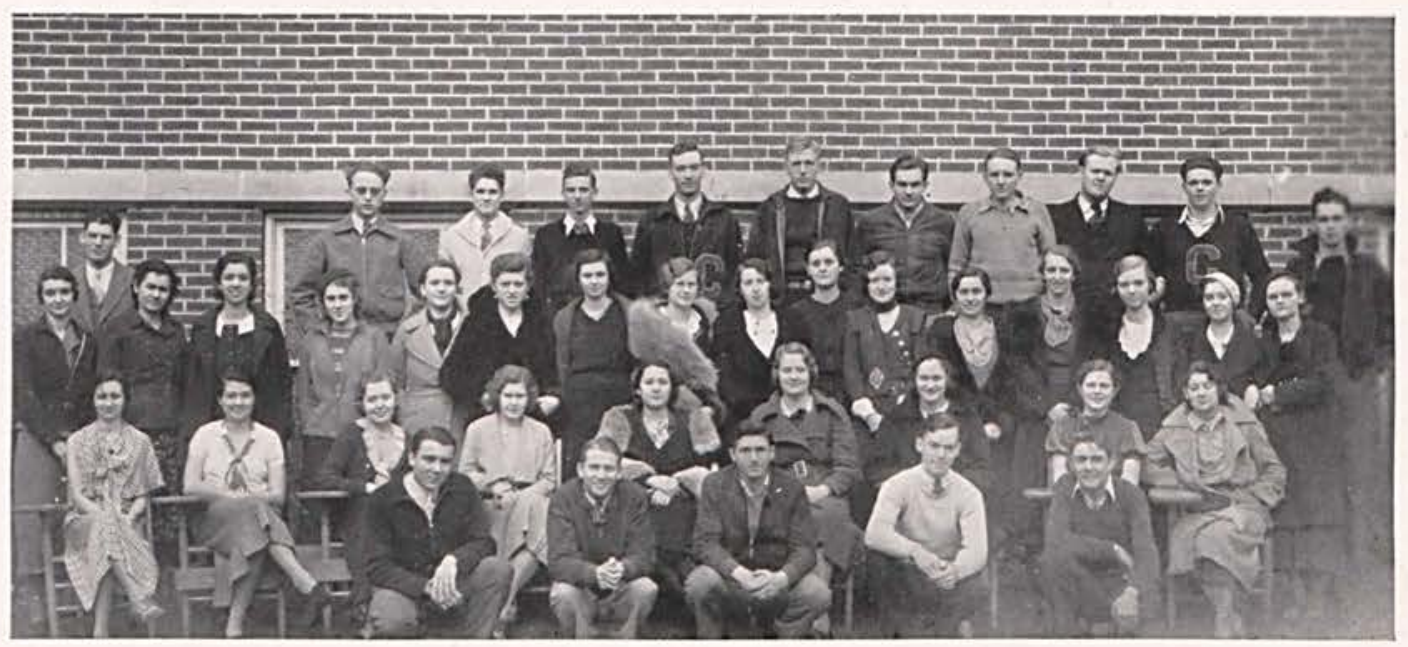

First Row: Potee, H. Murray, Finney, Kilpatrick, Wallace. Second Row: C. Brill, O. Brill, E. Bull, Cultice, Ritenour, G. Ackerman, Smith, J. West, Coulter. Third Row: E. Robe, Donaldson, Anderson, L. Robe, Chenoweth, Foster, Miller, E. Waddle, Henry, J. McCallister, Crager, Hine, Labig, D. Hartman, Hostetler, Bradley, Lunsford. Fourth Row: Ferryman, Burkert, W. Waddle, Ferguson, Thomas, R. Murray, W. Linton, Trubee, Mills, Taylor.

\section{PHILADELPHIAN PRESIDENTS OF THE PAST}

\author{
1895-A. Orr \\ 1906 - C. Ware \\ 1908-R. Hill \\ 1909-R. Ustick \\ $1911-R$. Conley \\ 1913-P. Turnbull \\ 1924-L. Markle \\ 1926-R. Choate \\ 1927-M. Webster and \\ R. Turnbull
}

1928-J. Johnson

\section{ORANGE AND BLUE PRESI. DENTS OF THE PAST}

1920-C. Duncan and D. McKune 1922-C. Ewbank

\section{PHILOSOPHIC SOCIETY}

$\begin{array}{ll}\text { President } & \text { First } \\ \text { Semester } \\ \text { Vice-president } & \text { Domer Murray } \\ \text { Secretary } & \text { Jane West } \\ \text { Treasurer } & \text { Walter Linton } \\ \text { Chaplain } & \text { Mildred Labig } \\ \text { Sergeant-at-Arms } & \text { Walter Kilpatrick } \\ \text { Reporter } & \text { Carolyn Brill }\end{array}$

Second Semester Paul Rife Walter Linton Wilma Chenoweth Carl Ferguson Russell Murray Edwin Potee Arthur Donaldson

This year's membership in the Philosophic Literary Society totaled fifty-one members.

The programs have consisted of readings, instrumental music, speeches, short stories, various numbers celebrating important holidays, boys' and girls' quartets, solos, duets, plays and reports of conferences which students attended. Two unusual programs of the year were the mock President's Ball and a Radio Program.

From the devotions to the social hour the meetings were enjoyed by all the members.

\section{PHILOSOPHIC PRESIDENTS OF THE PAST}

1906-F. Williamson

1908-E. Spahr

1909-E. Shaw

$1911-W$. Foster

1913-P. Ramsey

$1924-C$. Townsley

1925-M. Hunt

1926-D. Funk

1927-H. Huston and M. Bean

1928-C. Frazier

1929-J. Stormont and F. Graham

1930-L. Ford

1931-M. Hostetler

1932-C. Hutchison and W. Auld

1933-J. Free and H. Murray 1934-H. Murray and P. Rife

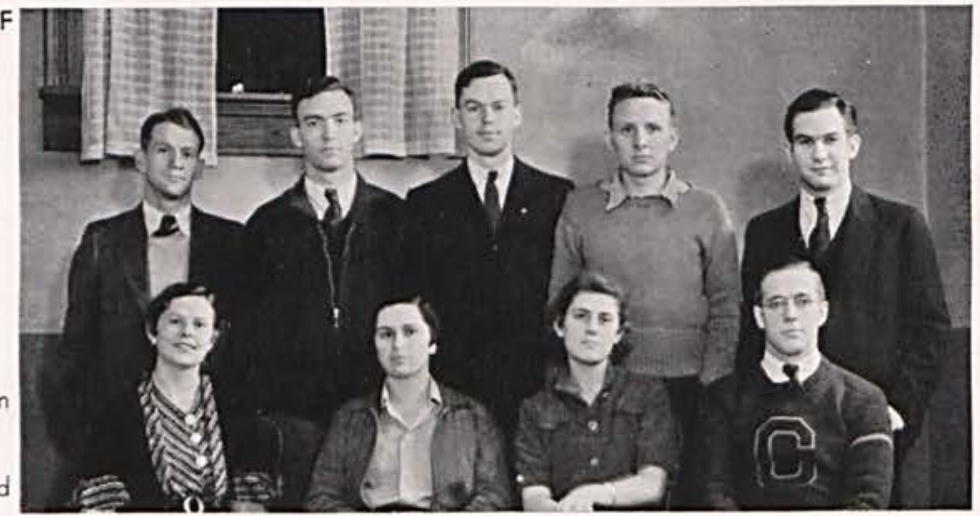

First Row: J. West, Labig. Chenoweth, Rife. Second Row: H. Murray, Ferguson, Kilpatrick, W. Linton, R. Murray. 


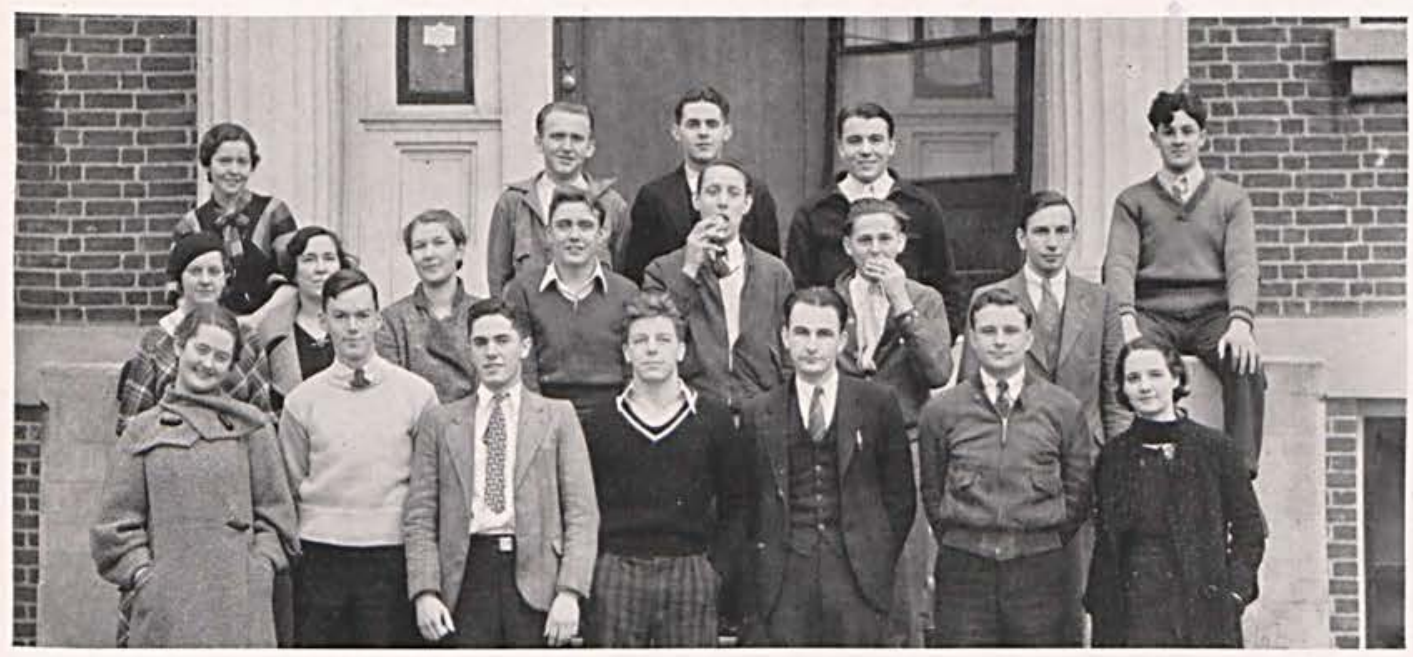

First Row: Wham, Kilpatrick, Gordon, Macknight, Ault, O. Ackerman, Skinnell. Second Row: Laybourne, Heintz, Bennett, Wallace, Harriman, Meyers, Angell. Third Row: Fisher, Geer, Trout, Potee, Cappola.

\section{BOARDING CLUB}

At the sound of the bell, there is a general rush for favorite positions along the firing line at the dinner table. As the meal progresses, the students toss puns as well as buns at each other. The enthusiasm expressed by everyone shows that there is one common interest at the twice-daily "meetings" of the Boarding Club to cater to the "inner man."

The Club each year elects a student to serve as steward. Along with the job goes the honor of collecting from the hungry students and paying the bills.

Around the tables of the Club many lasting friendships are formed, and the fine food is only one of many features that makes hours spent in the Library basement among the most pleasant memories of college days.

Bud Chamberlain capably fulfilled the duties of steward this year; and the twenty to twenty-five regular "eaters" were always more than satisfied with the meals prepared by Mrs. Morton and jolly, long-suffering, good-natured Mrs. Peterson, whose perennial good humor and friendliness was never ruffled.

BOARDING CLUB STEWARDS OF THE PAST

1921 -P. Duncan

1922-G. Moore

1923-E. Wright

1925-M. Hunt

1927-P. Brown

1928-J. Johnson

1929-C. Frazier

1930-F. Graham

1931-A. Townsley

1932-J. Murray

1933-P. Garlough

1934 -C. Chamberlain 


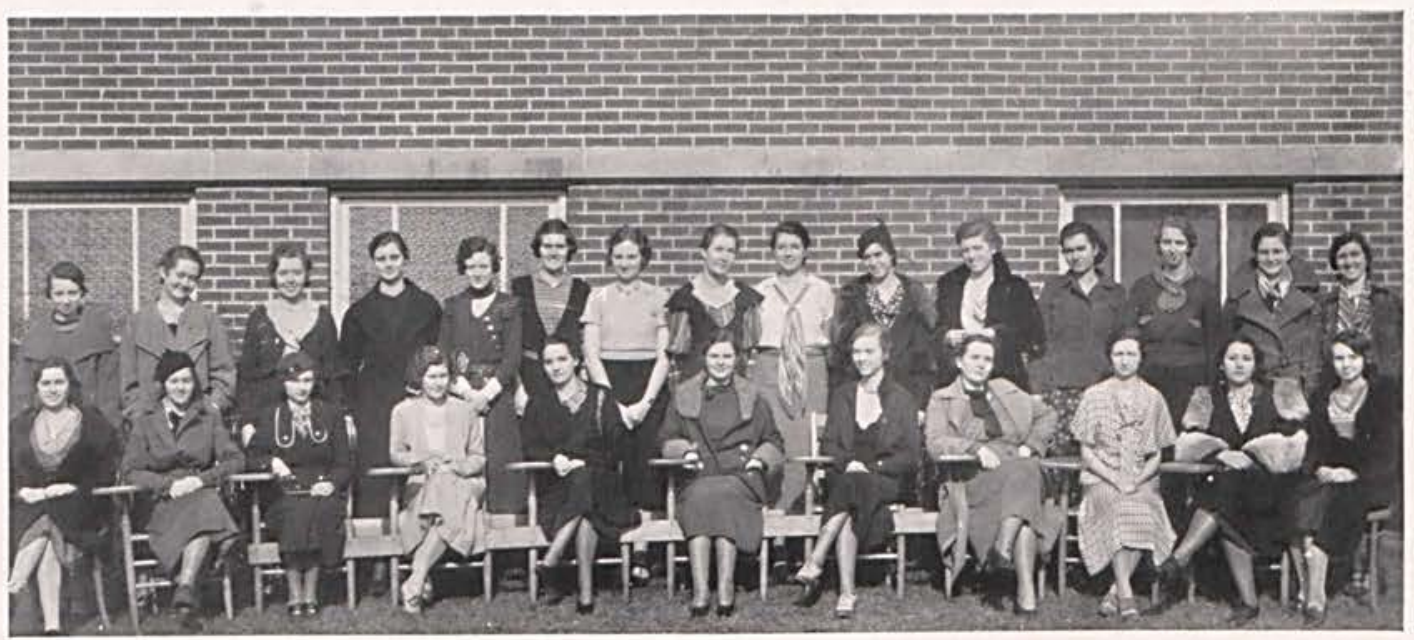

\section{GLEE CLUB}

First Row: Labig, Laybourne, Brock, Cultice, Skinnell, J. West, Hostetler, Foster, C. Brill, Ritenour, Pyles. Second Row: D. Corry, Wham, E. Bull, Crager, Hine, Dean, Berk, Bennett, O. Brill, Creswell, Miller, Anderson, D. Hartman, Mount, Mrs. Work.

\section{MUSIC DEPARTMENT}

Perhaps there is no department in the college which the students enjoy more, or which gives more pleasure to those outside the school than the department of music. This year found forty-five students enrolled in the department under the efficient direction of Mrs. Margaret J. Work. Each of these forty-five has received training that will be of great value to him, and each has really enjoyed his work.

The department of music had one graduate this year-Dorotha Corry-who completed the work in the Department of Piano. Miss Eleanor Bull appeared in a Junior recital in piano, April 26, 1934.

A new musical organization in the college is the orchestra which was organized to play at the college activities the last week of school.

Each of these organizations has had a very successful year due to the faithfulness of the members and the untiring efforts of the director, Mirs. Work.

First Row: Stevenson, D. Hartman, Bennett, E. Bull.

Second Row: Ritenour, Anderson, Skinnell, Wham.

Third Row: Burkert, Richards, Trout, E. Corry, Harriman, Rife.

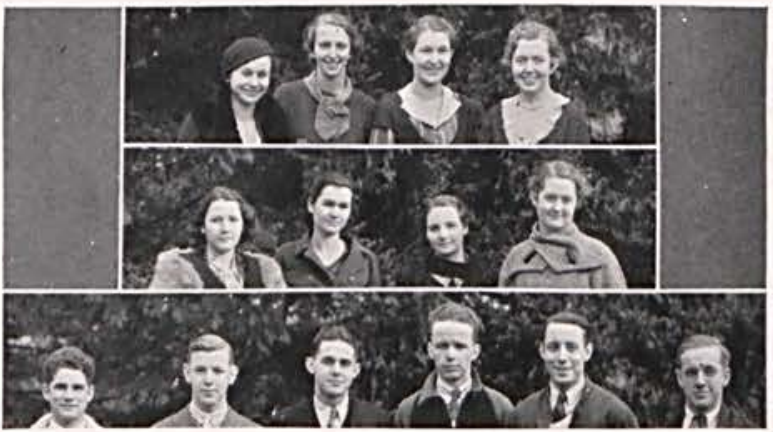




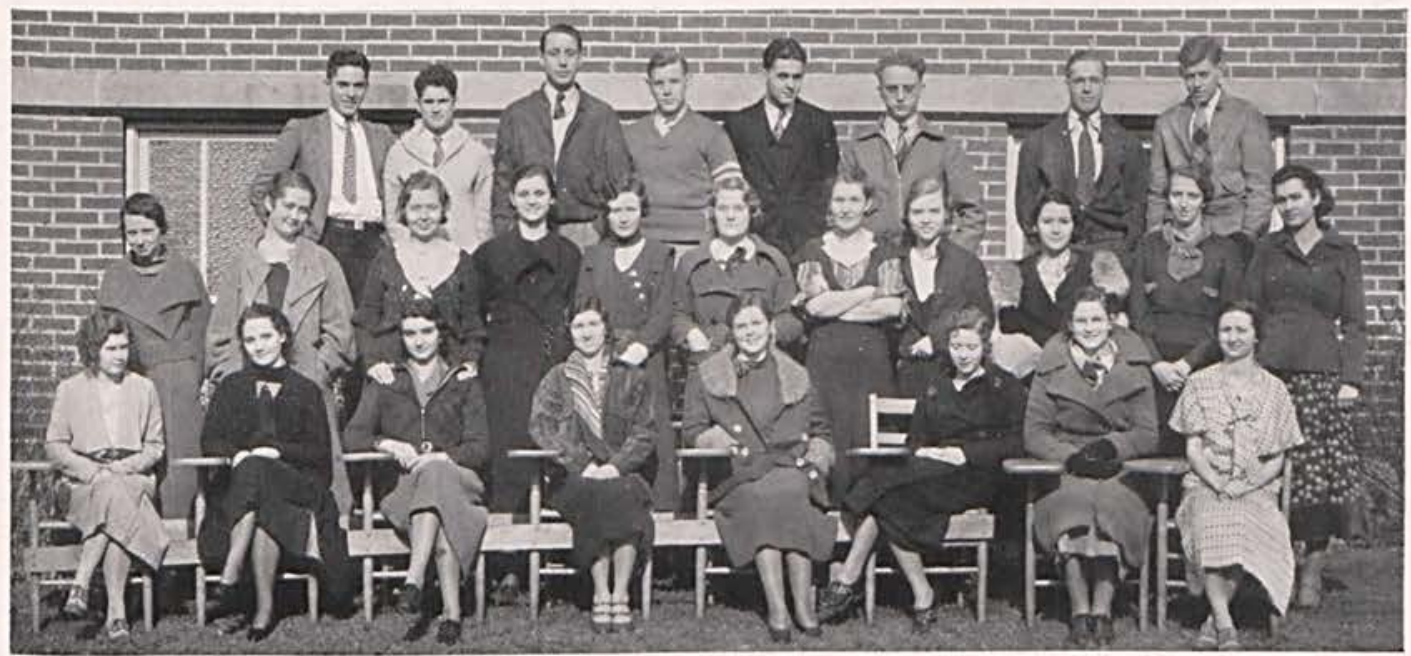

\section{MIXED CHORUS}

First Row: Cultice, Skinnell, E. Robe, Mrs. Work, J. West, M. L. McLaughlin, Mount, C. Bitl. Second Row: D. Corry, Wham, E. Bull, Crager, Hine, G. Ackerman, Bennett, Hostetler, Ritenour, D. Hartman, Anderson. Third Row: Gordon, Burkert, Harriman, Richards, Trout, Ferryman, Rife, Christian.

\section{GLEE CLUB}

The Girls' Glee Club of twenty members meets twice a week, on Tuesday and Thursday, to sing an hour together. They have memorized many selections, both sacred and secular, which they have used in their public appearances. The Glee Club took part in two recitals this year, one at Christmas time, the other during the last week of school. They sang at the Lincoln Day program at Wilberforce, and presented sacred concerts at the First Presbyterian Church in Xenia and the U. P. Church of Cedarville.

\section{MIXED CHORUS}

The Mixed Chorus, an organization of both boys and girls of the college, meets each Monday and Wednesday night for an hour's practice. These practices are always pleasant events, though quite a bit of work is mixed in with the pleasure in memorizing a large number of selections. This organization also appeared in public recital twice a year, took part in the "International Sing" at Wilberforce, and helped out with various college programs.

\section{QUARTETS}

Cedarville College is proud of its three quartets. The Cedar Needles are Eleanor Bull, first soprano: Maxine Bennett, second soprano; Doris Hartman, first alto: Nina Stevenson, second alto, first semester and Dorotha Corry, second semester; Mrs. Work, accompanist. These girls have entertained various clubs and churches in Cedarville and surrounding towns. They appeared before the Columbus Epworth League Conference and presented sacred programs in the First Presbyterian Church, Xenia, and at the Greene County Infirmary.

The Orange and Blue Serenaders were also very popular and much in demand at college and town functions. They were Anna Jane Wham, first soprano: Georgia Skinnell, second soprano; Dorothy Anderson, first alto; Harriet Ritenour, second alto; Genevieve Jamieson, accompanist.

Last but not least is the men's quartet which has taken the name, Neapolitan Knights. This quartet consists of Donald Trout, first tenor; John Richards, second tenor; Robert Harriman, first bass; Eugene Corry, second bass. Though this was the first year for all of the members, they learned to harmonize very well. They appeared several times in Cedarville and in South Charleston and Xenia. 


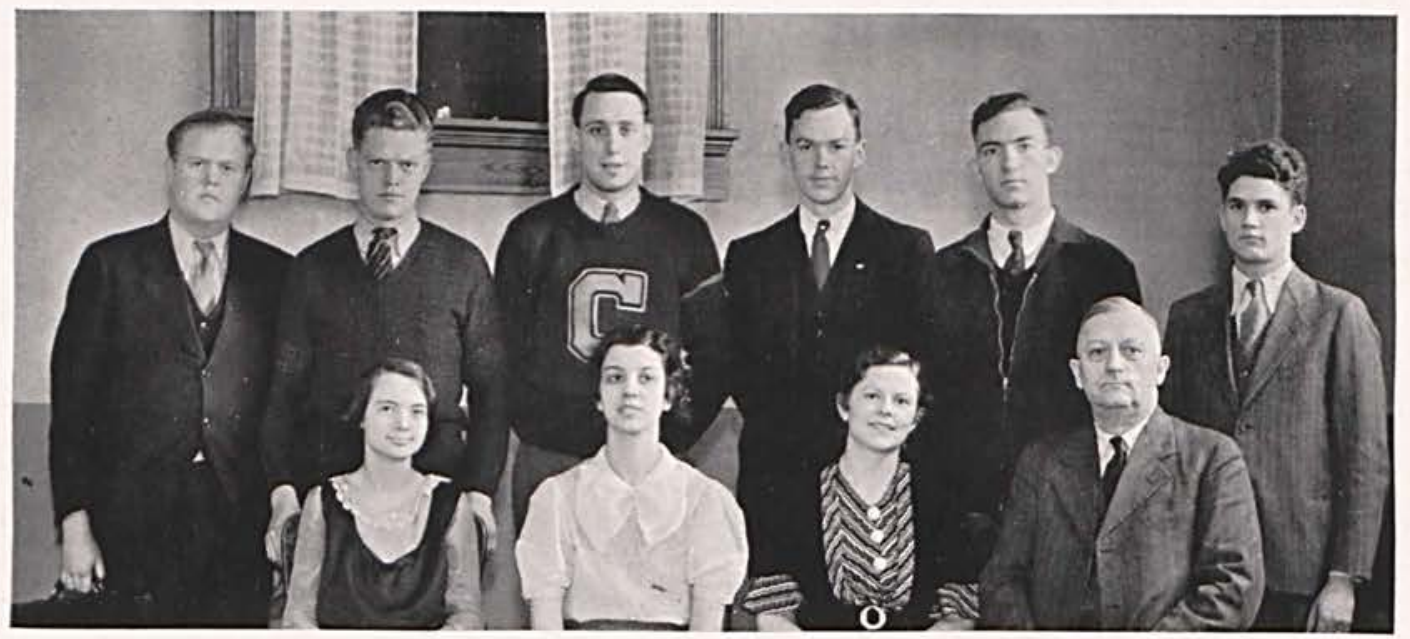

First Row: Pyles, L. Robe, J. West, Dean Steele.

Second Row: Trubee, J. West, Harriman, Kilpatrick, Ferguson, Burkert.

\section{DEBATE QUESTIONS OF THE PAST}

1927-Direct Primaries

1932-Recognition of Russia, and Women in Industry

1933-National Regulation of Banking

1934 - Powers of the President

\section{DEBATE}

When the call for debaters was sounded this year, two of the old guard returned, bringing with them seven others - a total of nine who aspired to uphold in verbal combat the honor of old C. C. The question selected for study this year was "Resolved, That the powers of the President be substantially increased as a settled policy (Powers as of March 4, 1933)". After several weeks of intense reading and research, the squad was divided inta three teams, consisting of Kilpatrick, Trubee, Joe West as "yes men" and Robe, Pyles, Jane West, Ferguson, Harriman and Burkert as the two negative teams. On the 23d of February the teams under the management of Dean Steele journeyed forth to meet the enemy at Manchester third annual College Invitational Debate Conference. "Veni, Vidi, Vici" in the passive voice tells the story in nine out of ten cases, the lone victory being that of the affirmative team over Goshen. However, the new members felt that they had learned what it was all about, as the girls' negative readily showed when they defeated Rio Grande in the last debate of the season at Cedarville. The affirmative team engaged in debates with Morehead, Wilberforce and Rio Grande. Thus the curtain rang down on debate at Cedarville for '34, but with six experienced debaters returning next year, prospects are bright for C. C.'s return to the sensational win records of recent years. 


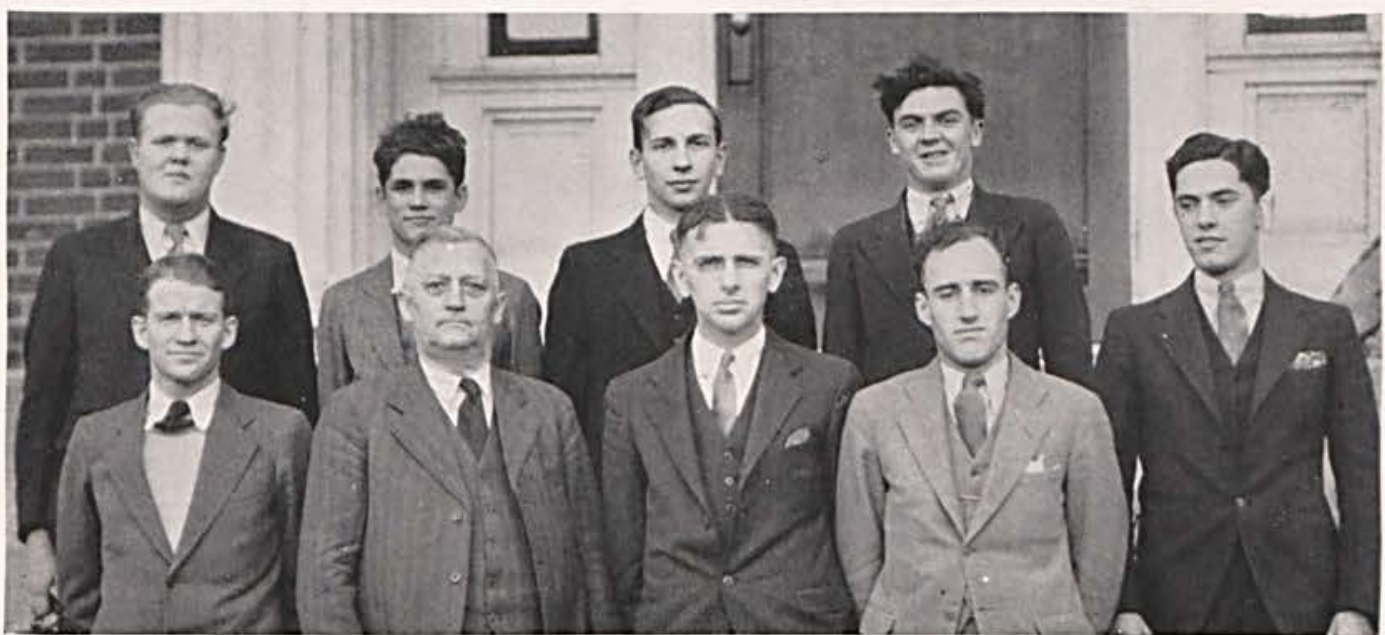

First Row: H. Murray, Dean Steele, P. McLaughlin, Spencer, Gordon. Second Row: Trubeo, Burkert, Angell, Grube.

MONKS' CLUB

President Paul McLaughlin

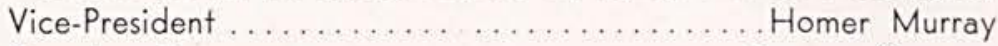

Secretary-Treasurer..................... Eugene Spencer

Accompanist....................... Elsie McLaughlin

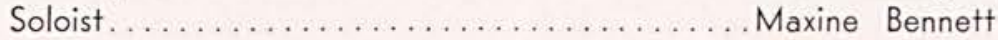

Faculty Advisor..................... Dean C. W. Steele

At the beginning of the school year the ministerial students of the college organized the Monks' Club for the dual purpose of doing social work and promoting closer contacts for the embryo ministers. The chief activity of the club was to conduct services at churches in near-by communities when asked to do so.

During the first semester regular meetings were held each week to discuss various problems and plans for the club. During the second semester the club held services in many of the surrounding towns, including Dayton, Xenia, London, Columbus, Plattsburg, Carlisle, and Selma. The club conducted a number of services at the local churches, and held special services at other churches in connection with evangelistic meetings, Easter programs, and other similar occasions. In the final meeting for this year, the Club joined with the Girls' Glee Club in presenting a program at the First Presbyterian Church, Xenia. At all of these services a complete worship program was presented featuring three speakers and special music. Upon several occasions the club was assisted by Mrs. Work and members of the music department of the college.

Next year the Monks' Club will continue with its work, as all but one of the members will be back. It is hoped that the organization may enlarge its membership and thus increase its scope of service next year. Membership is open to any student who wishes to prepare himself for any type of social service, or who is interested in the Gospel ministry. 


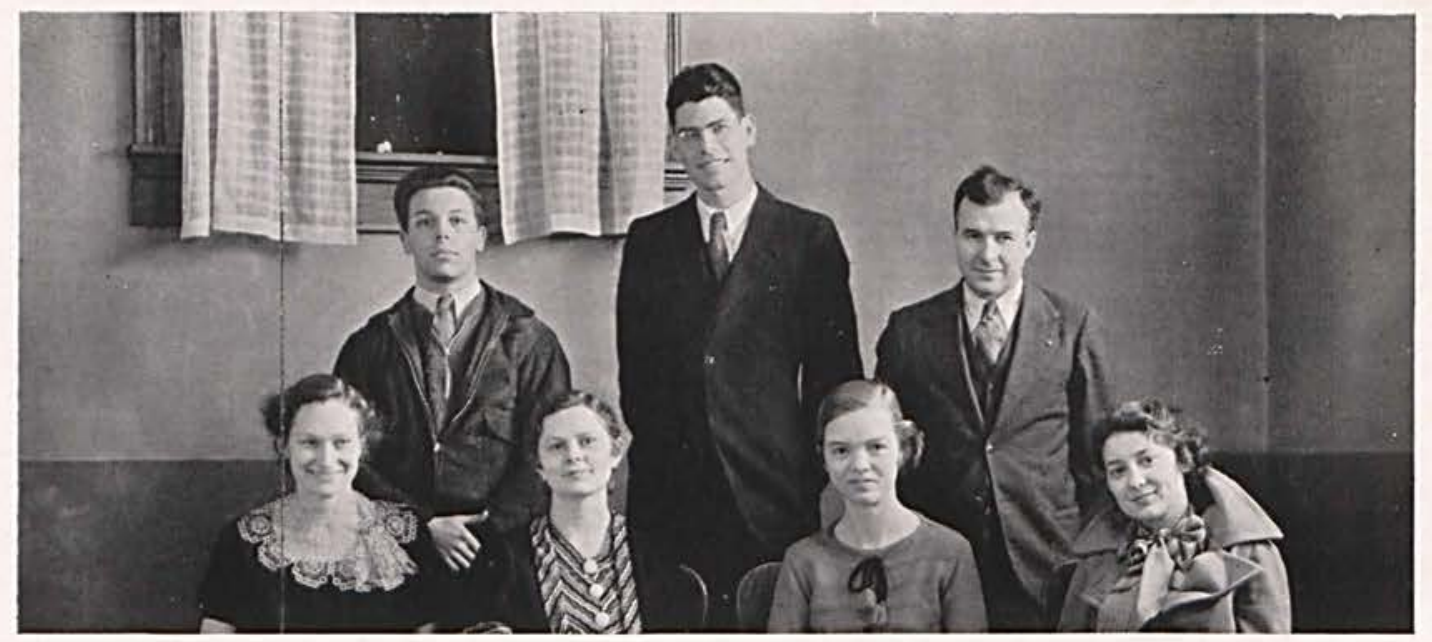

First Row: Smith, J. West, Hostetler, Coulter.

Second Row: Macknight, Donaldson, J. Murray.

\section{WHISPERING CEDARS}

One of the newest organizations is the staff which edits and prints our bi-weekly paper, "The Whispering Cedars." The staff chosen by the student body has proved its worth by giving to the students a paper chuck-full of news and happenings about campus life, as seen by the school paper editress, Carma Hostetler, and her assistants, Jock Murray, business manager: Regina Smith, sports editress; Art Donaldson, features editor; Bill Macknight, sports editor; Jane West, Eleanor Coulter, and Helen Baker, typists.

\section{WOMEN'S ADVISORY BOARD}

The college owes a great deal to the untiring efforts of the members of the Women's Advisory Board, who have furnished the means whereby many needed improvements have been made in our college. At the annual Homecoming Banquet, the Women's Advisory Board provided a bounteous meal, and during the year the Board has served banquets for other organizations. These faithful women work for no selfish interest but spend their profits for worthy purposes. Their latest contribution to the college is the redecorating of the office.

First Row: Clemans, Iliff, Stormont, McChesney, Oglesbee, Elias, Hartman.

Second Row: Richards, Dobbins, McMillan, Townsley, Johnson, Hostetler, Kuehrmann, Steele, Auld, Wright.

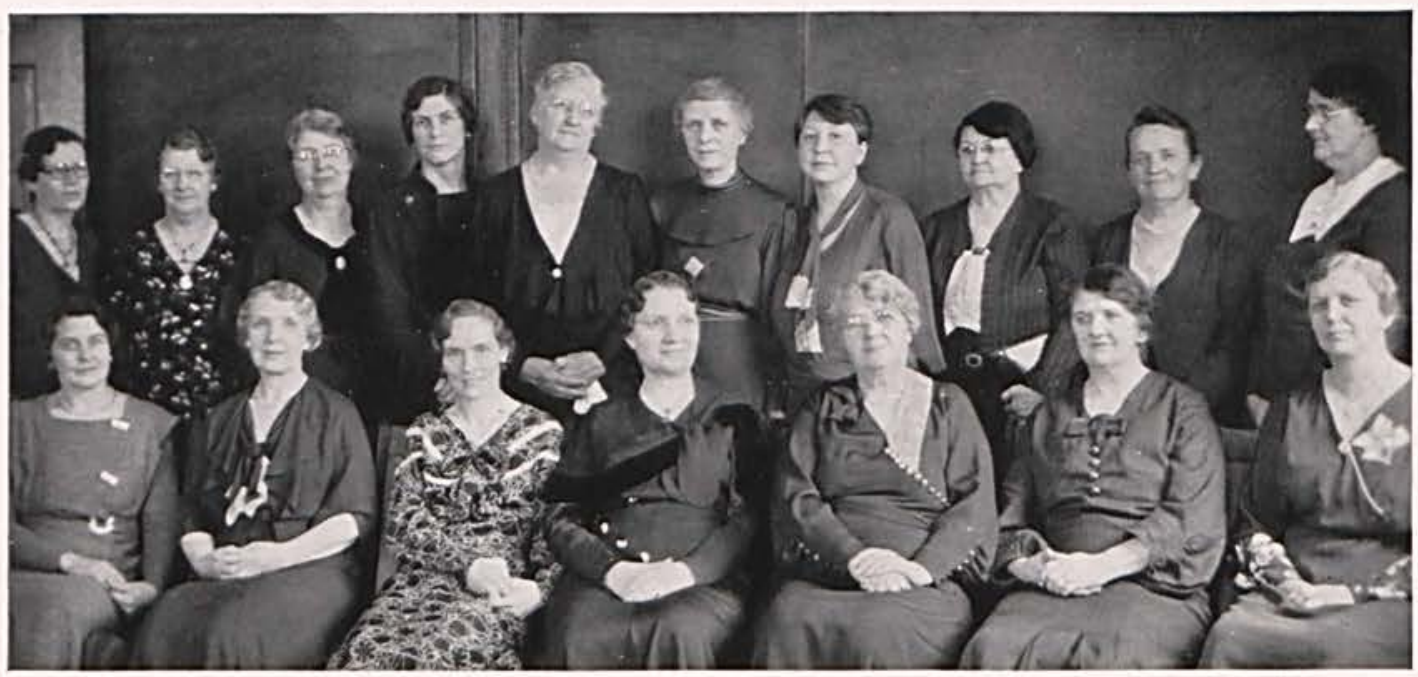

Page Forty-two 


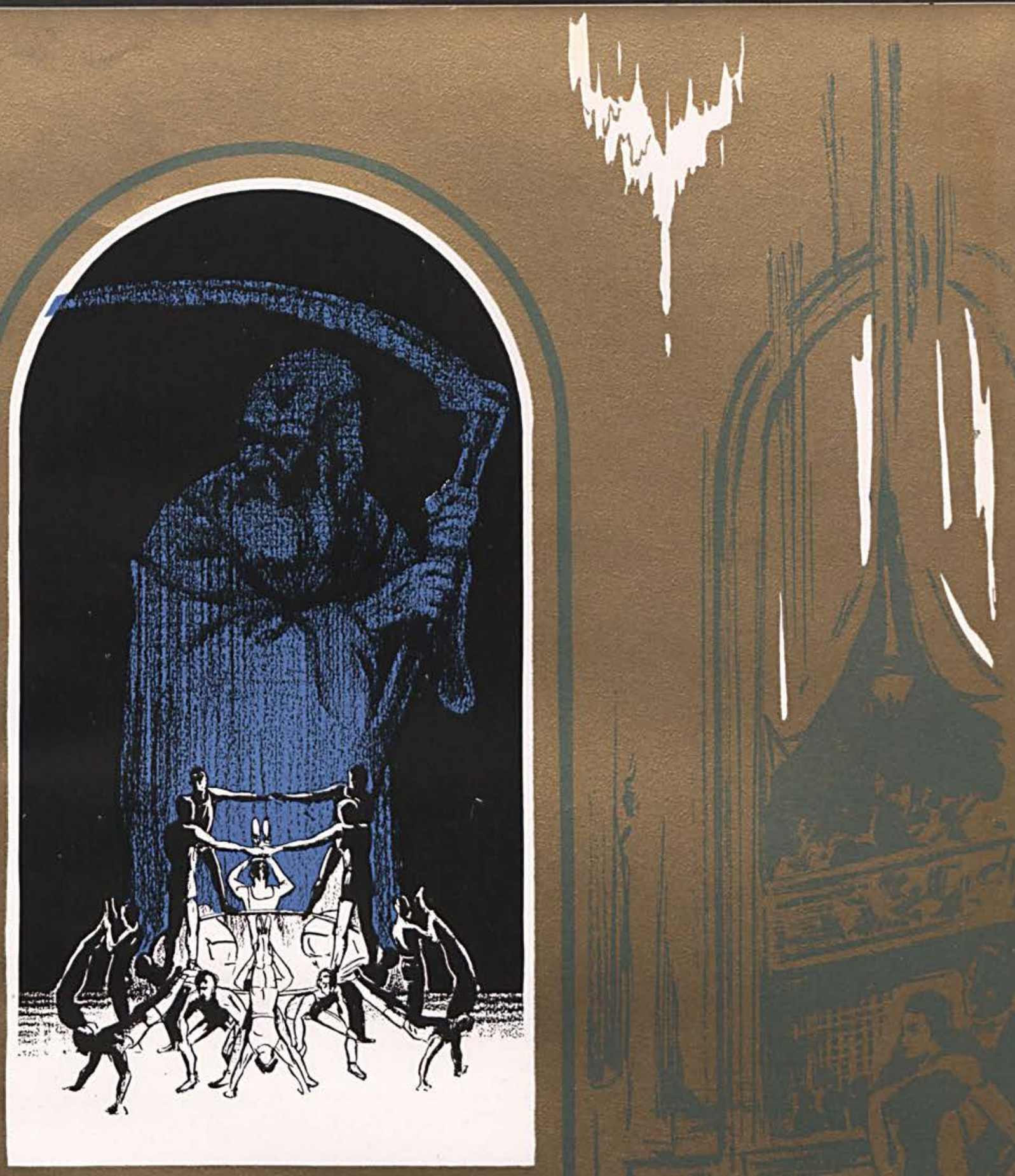

10

0

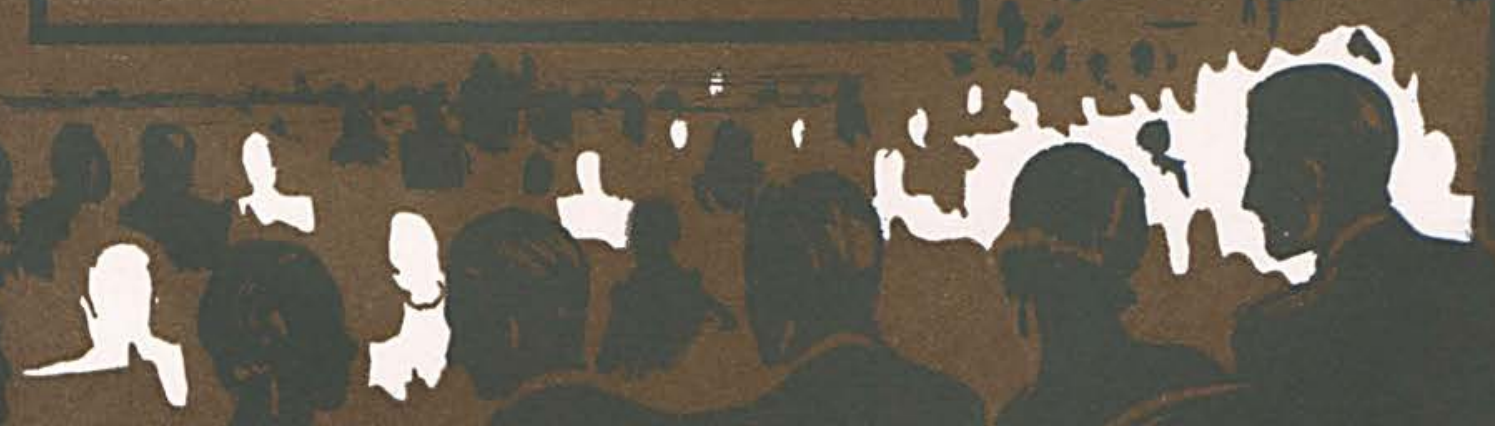

ACT THREE . . ATHLETICS 



\section{FORTY YEARS OF ATHLETICS}

Cedarville's athletic career has been a checkered one, going from good to bad and worse to better. The history of athletics begins simultaneously with the history of the college, for, while no athletic organization was sponsored and financed by the college in the early days, neither was it discouraged. The youths, inclined to display their prowess on the gridiron and diamond, were given all encouragement and the interest which these students had for developing their abilities in handling the pigskin and bat is manifested by the fact that they were willing to employ a coach at their own expense.

Mr. Blackburn was the first coach employed by the college, taking his position in 1921. Following Blackburn the men at the head of the athletic department of the college were C. P. Warner, J. A. Talcott (who coached one year in addition to his regular duties as music director), E. F. Diedrich, A. M. Tuttle, R. M. Borst and the present coach, J. W. Ault.

The football season of 1896 stands out as one of the highlights in Cedarville's athletics. Much credit for the success of the team that year is due J. C. Scarff, who coached the team and played the position of left-half. The record of scores for the season is quite interesting and one about which Cedarville will long boast: Cedarville, 0, Xenia, 0; Cedarville, 14, Antioch, 0; Cedarville, 2, Wittenberg, 0; Cedarville, 36, Wilberforce, 0; Cedarville, 40; London, 0; Cedarville, 4, Wilmington, 4.

On this greatest of all teams played some of our prominent alumni, namely C. C. Morton, J. A. Orr, J. R. Harper and Wallace lliffe with his brothers Walter and Harry.

Cedarville has not always been so successful, and there have been long periods when they played losing games, but always the spark of life was there and was kindled into flame at intervals.

In 1903 Alford Memorial Gymnasium was dedicated and this year the first basketball teams were organized. The girls had a prominent place in this sport. Cedarville has the distinction of having the first girls' team in the state. A notable event occurred in 1911 when the girls' team defeated Miami University, for nine years undefeated, and wrested from that school the championship of Ohio. Student publications of those days give the information that the girls had to play a game in order to draw a crowd for the boys' game.

In recent years Cedarville has been more victorious in baseball than in the other sports. defeating colleges with much larger enrollments.

While our college has experienced its bright days and days of darkest gloom in its athletic career it has maintained through its four decades a never failing spirit of loyalty and fair play. 


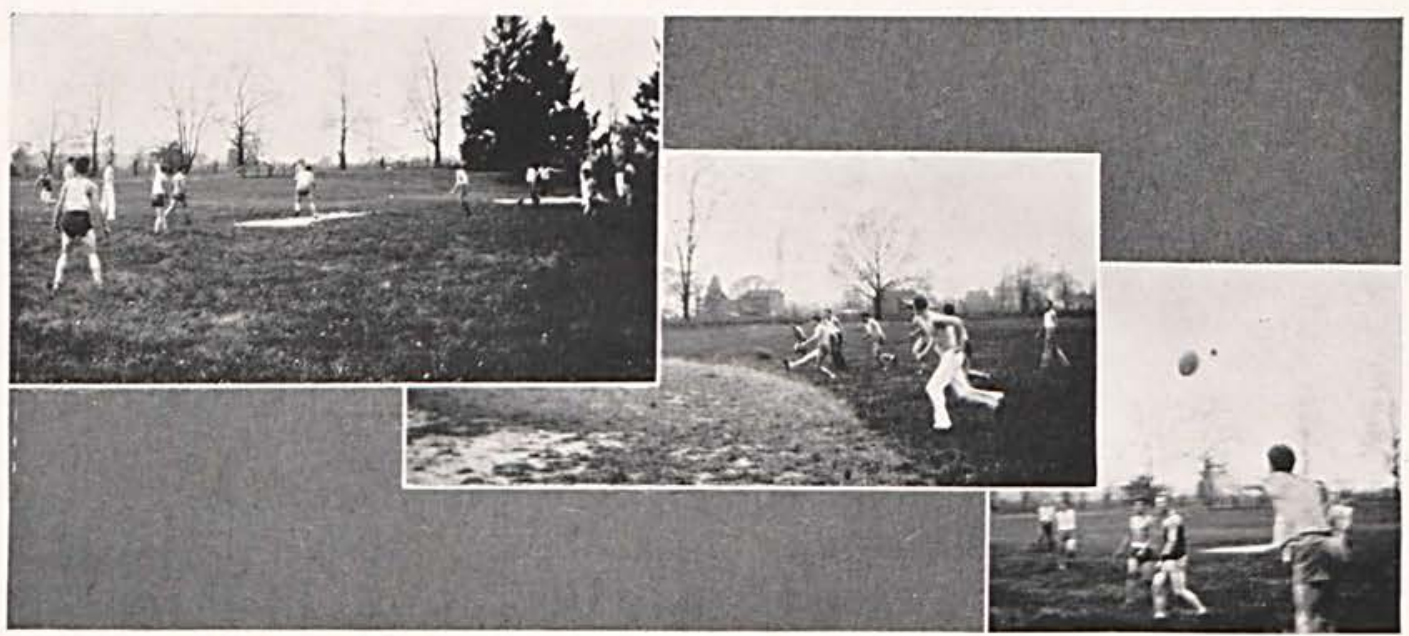

\section{PHYSICAL EDUCATION}

The physical education department this year, under the direction of Coach Ault and his able assistants, "Red" Murray, "Smitty" Smith, and "Bob" Ross, offered a complete and varied program, to meet the needs of the students, at the same time providing interesting competition.

"Red" conducted a program of calisthenics, softball, volleyball, basketball, and soccer for the men. "Smitty's" program is reviewed on the following page. "Bob" had charge of special classes in wrestling, boxing, tumbling, and fencing. Richards and Corry proved outstanding in wrestling: $G$. Ross and Macknight were outstanding in boxing; Tobias, Bull, Dobbins, and West showed fine form with the foils: Meyers and Cappola demonstrated excellent possibilities in tumbling. Mount and Anderson, two feminine aspirants to "King of the Blade," were not greatly outdone by the male fencers in consideration of the fact that they were late additions to the ranks of this sport.

Soon after college had started, Coach Ault appointed eight men from the student body to act as captains for intramural volleyball teams. A tournament was staged for the benefit of the blood-thirsty student body. Sad to relate, after many titanic struggles and closely contested games, only one team was able to call itself champion. However, like all good champions, the winners took that coveted honor with good grace. Members of the winning combination were L. Ross, Mills, McCallister, Richards, Spencer, Tobin, R. Ross (captain).

At the close of the varsity basketball season, another colossal struggle for supremacy was staged in the innocent-sounding form of a class tournament in basketball. Little did any student know the ghastly chaos in which those martyrs were to struggle. For in these days to be chosen to play on a class team is a judgment of martyrdom itself. Eventually the officials, time and place were agreed upon, and so continued the history-making epoch of an ambitious Freshman class, who emerged triumphant out of the maelstrom. 


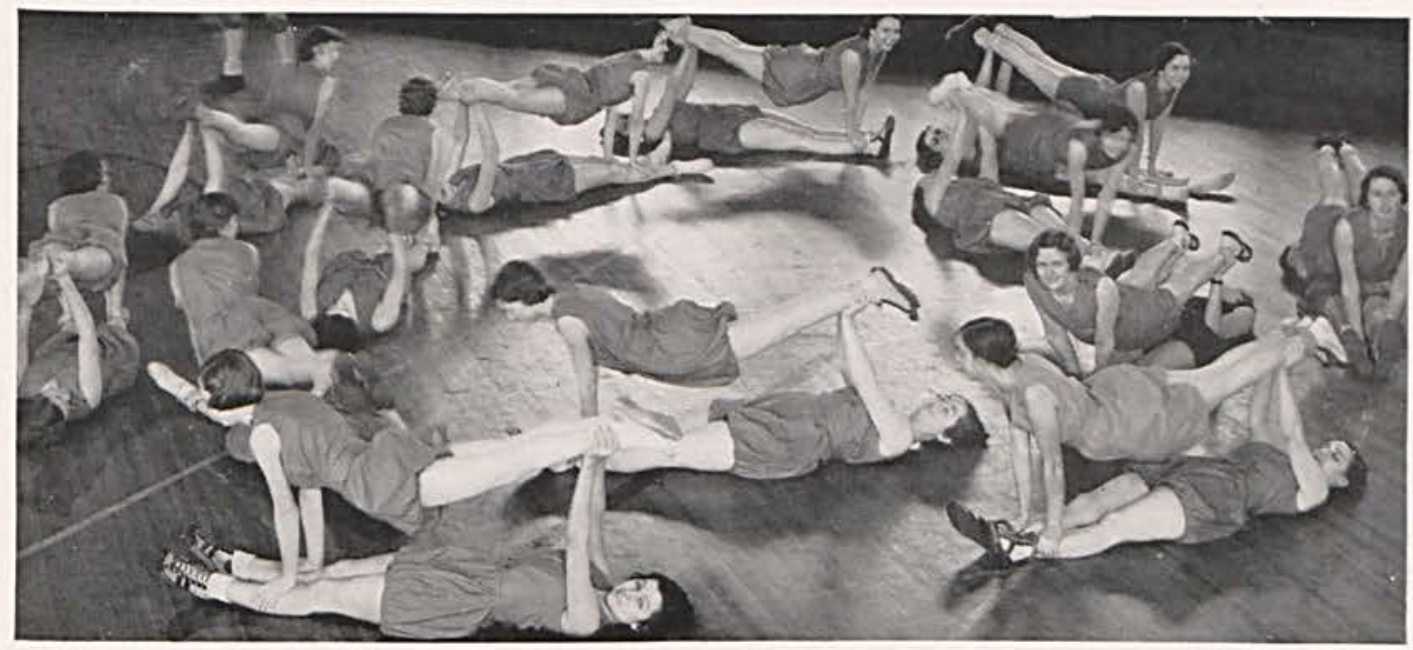

\section{GIRLS' GYM}

The girls of the physical education class this year found an enthusiastic instructress and a well-planned and diversified program into which they could easily fit their individual preferences.

The class as a whole carried out a well-balanced program of basketball, gymnastics, games, and hikes. By this method individual abilities and interests were met and the cooperation and enthusiasm of the whole group was secured.

The girls who chose aerial dart as their specialty developed a decided liking for the game and considerable skill in playing it. They seemed to be the first group on the floor each day, practicing with no little concentration. The activities in this sport were entirely intramural, but interesting nevertheless.

The basketball team had a very successful season. They played six games and succeeded in carrying off all but one of them. The last half of the season the team played under boys' rules and met these somewhat stiffer requirements very well.

Wins were recorded against these teams: Selma, 27-20; Cedarville High, 29-25; Alumni, 20-8; C. W. A. Independents, 20-8; 3rd Lutheran of Springfield, 20-17. The only defeat was a close 15-10 decision at the hands of the Cedarville Independents.

The season was closed with a short and very funny burlesque game against the College Reserves who attired themselves in the beautiful costumes from a fairy pageant.

The final work of the year for the girls was the preparation of the dances for the Cedar Day Program. Much energy and effort was spent and some very praiseworthy numbers were prepared for the program under the direction of Miss Smith.

\section{GIRLS' BASKETBALL CAPTAINS OF THE PAST}

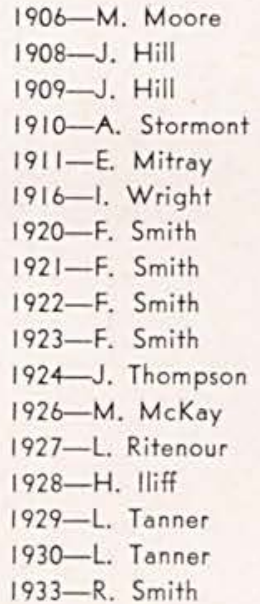




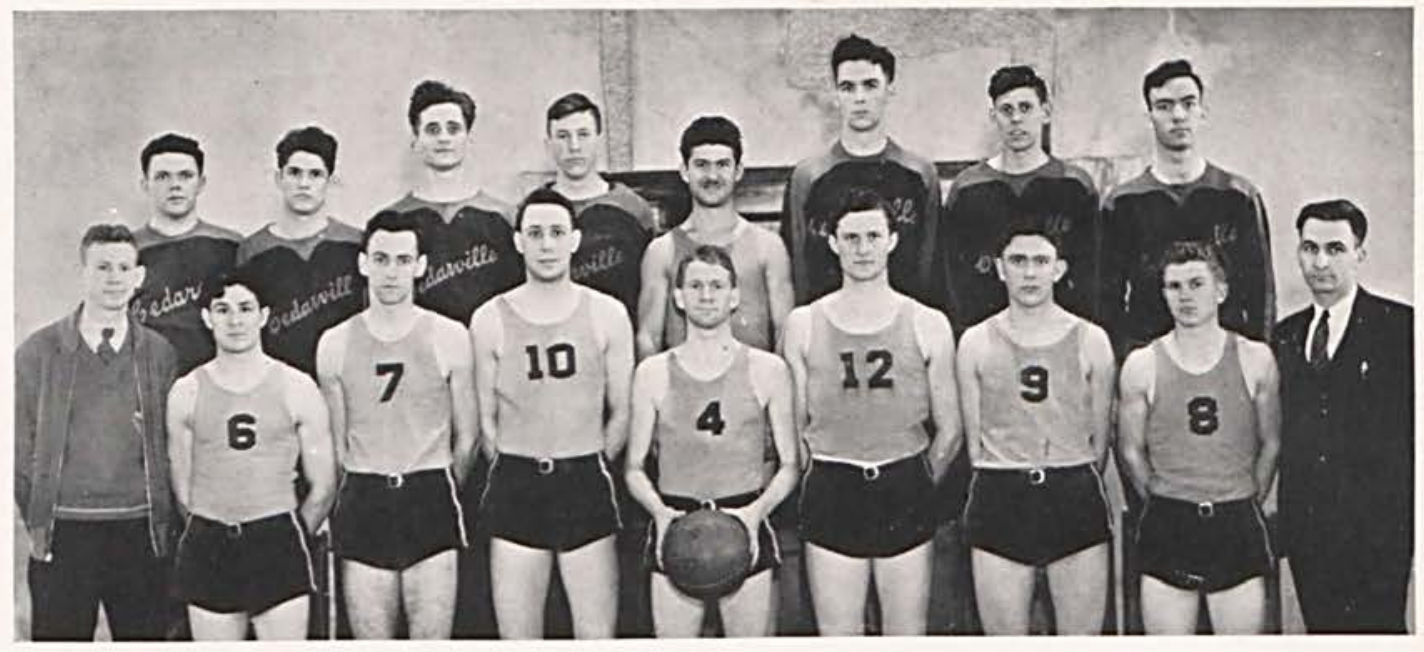

First Row: Mgr. Tindall, Cappola, Harris, Harriman, Capt. Murray, Swaim, Wallace, Waddle, Coach Ault. Second Row: Mills, Burkert, L. Ross, Garlough, Hargrave, Taylor, Christian, Ferguson.

\section{BASKETBALL SEASON 1933-1934}

BASKETBALL CAPTAINS OF THE PAST

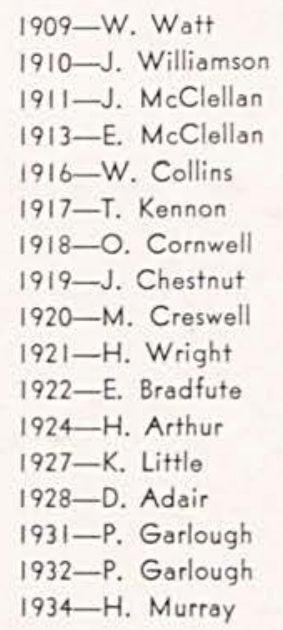

Page Forty-eight
Somewhat handicapped in size and playing experience, Cedarville's basketeers did not have a majority of wins in their season's contests. However they made a very creditable showing in the Northwestern Ohio Conference in scoring strength as indicated by the total number of points collected during the season. The Yellow Jackets ranked second only to Wilmington in this classification.

If the fact that the team was composed mainly of freshmen this year proved a handicap, that fact seems to auger well for next, because with a little more experience, the team should develop into a real championship combination. Three of the nine letters awarded were won by freshmen, so that next year will see a team of veterans familiar with each other's style of play.

The team loses two men by graduation, Capt. Murray and Hargrave. Murray was honored with a berth at guard position on the second all-conference team.

Letters were awarded to Murray, Hargrave, Harriman, Cappola, Christian, Waddle, Swaim, Harris, and Turner.

During the season Cedarville collected four hundred eighty points to her opponents' five hundred forty-three. This appears to be a very small margin of difference when one remembers that the Yellow Jackets won only five games out of fifteen. 


\section{HOMECOMING GAME}

Cedarville met Defiance on the local floor in the homecoming game this year, and the gym full of alumni, faculty, students, and others witnessed one of the hardest fought, nipand-tuck games that was ever played on the home court. From the very first blast of the whistle to the final shot of the gun at the close of the last overtime, the game was played hard and fast with neither team ever leading the other by a margin of more than six points. At the close of the regulation playing time the teams were tied in score at thirty-eight apiece and after a few minutes rest continued the fight for a period of three minutes. At the close of this period the teams were still deadlocked at 40-40. Another rest and another three minutes of fighting. Another shot. Another checkmate in score, 41 all. And so on, far, far into the night until 11:30 o'clock, when the game came to an end, with Cedarville leading Defiance by one point, 44 to 43 . This game was the season's high water mark for thrills and spectacular playing, and every member of the squad was used at some time during the contest.

\section{SEASON'S SCORES}

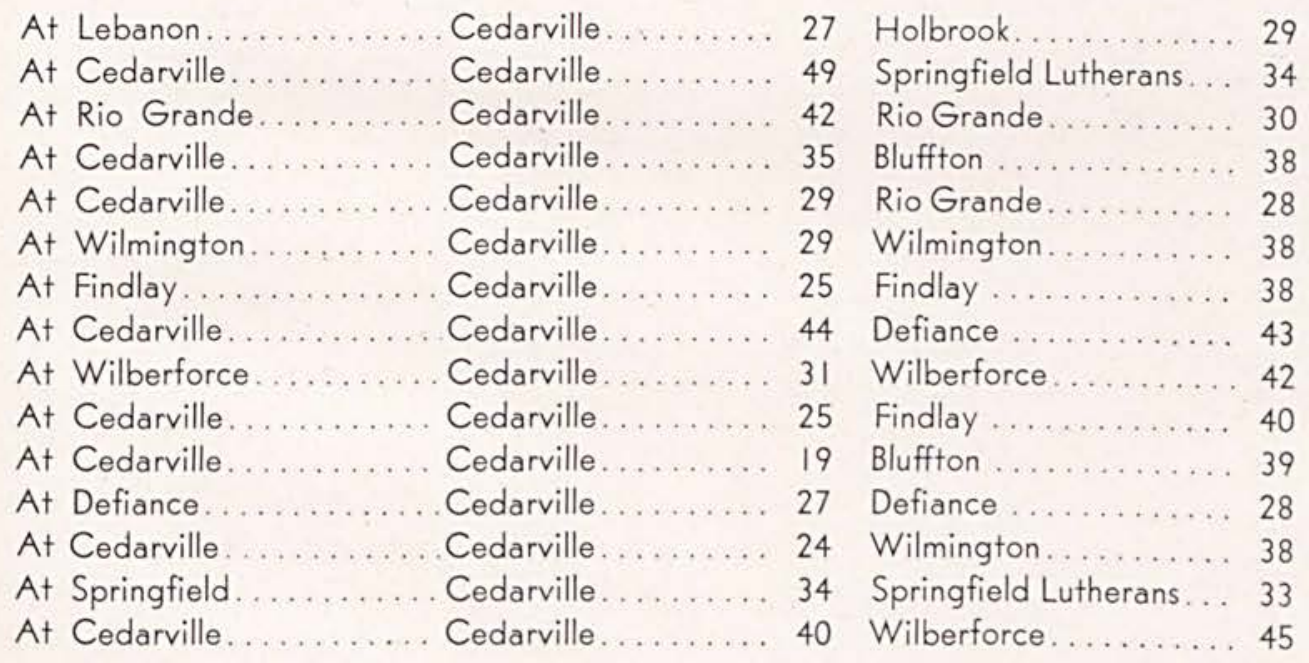




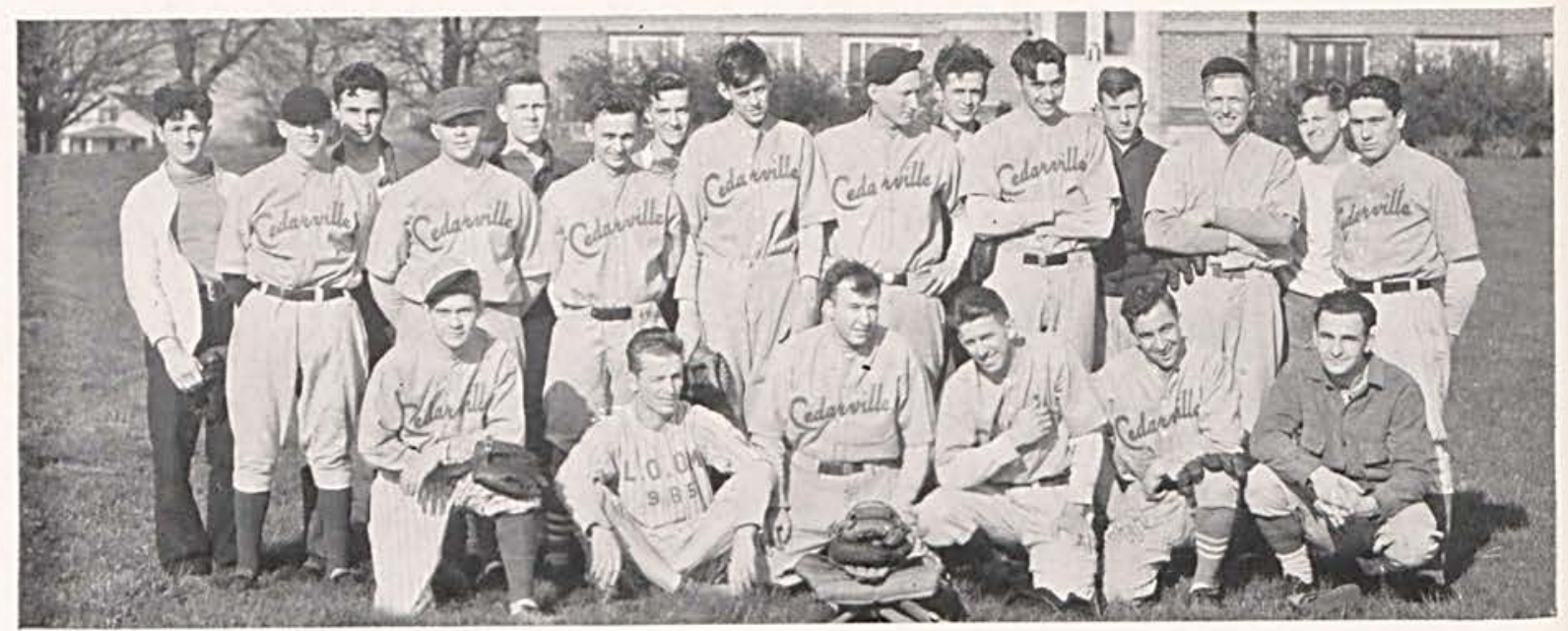

First Row: Hargrave, R. Ross, J. Murray, P. Garlough, Kitchen, Coach Ault.

Second Row: Cappola, H. Murray, Fox, Mills, Richards, Paxson, Reed, Christian, Bost, L. Ross, Spencer, v. Garlough, Thomas, Meyers, Miller.

\section{BASEBALL CAPTAINS OF THE PAST}

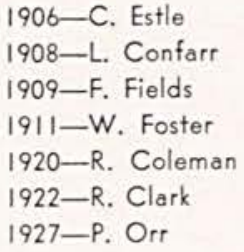

\section{BASEBALL 1933}

Though they did not win the Northwest Ohio Conference championship, Coach Ault and his diamond stars came very close to that goal by completing the season with five games won and four lost, to finish second in the conference standing. Three of these games lost were with non-conference teams representing much larger colleges from other leagues. Cedarville's diamond stars made this commendable showing behind the able pitching of Captain Garlough and Miller.

The men lost to the team through graduation are: Garlough, Richards, Spencer and Bost. Although all four were valuable letter men, some promising freshman material and almost a full team of undergraduate lettermen turned out at the spring summons, so that the team of ' 34 should be as strong if not stronger than the one of ' 33 , and Cedarville should again be fighting for an upper berth.

Those awarded letters for the spring of 1933 were Garlough, Richards, Spencer, Bost, Mills, Ross, Hargrave, J. Murray, H. Murray, Christian, Kitchen and Cappola. 


\section{WEST LIBERTY}

Inability of the Cedarville sluggers to "get going" in their opening game cost them a defeat of 6 to $I$ at West Liberty Teachers College in West Virginia. However even a losing team may have its moment as did our boys when Stew Kitchen connected for a home run, for the only Cedarville score.

\section{MIAMI}

The Miami ball tossers defeated the Cedarville nine at Oxford, 5 to 3 , in a closely contested game. Our boys showed much improvement over the previous week's game, in spite of the fact that Miami had a much better team than West Liberty.

\section{WITTENBERG}

Our boys were no longer to be denied, so when they journeyed to Springfield a few days later, they trounced Wittenberg to the tune of 4 to 2 . Miller's superb pitching proved too much for the Springfield lads to cope with.

\section{BLUFFTON}

The precedent of the week before ran true to form in the first home game of the season, against the Beavers from Bluffton. Although the game was uninteresting from the score standpoint, Cedarville played very consistent baseball, and wound up on the long end of a 10 to 4 count.

\section{WILBERFORCE}

The ball game was rained out on the date this contest was originally scheduled and consequently the team had a week of rest. Because of this rest success again crowned their efforts when they finally invaded Wilberforce. The colored boys did their best, but it was not quite enough to keep them from being on the short end of a 7 to 4 count.

\section{WILMINGTON}

Next, the Green Tornado came over to the Cedarville diamond with high hopes of vanquishing that seemingly unimportant school, but these hopes were downed because of Peter's masterful pitching and his team-mates' excellent support. Wilmington, although scoring four runs, was no match for the Yellow Jackets, and our visitors were forced to return home with the sad report of "We lost by a score of 5 to $4 . "$

\section{WITTENBERG}

The refurn game with Wittenberg proved to be the hardest-fought game of the season. The score was knotted at I to I until the fourteenth inning, when Wittenberg eked out another counter to make the score 2 to 1 . Cedarville was unable to score in her half of the fourteenth inning, and thus ended perhaps the closest game ever played on the home diamond. Garlough pitched the entire game in his usual fine style.

\section{BLUFFTON}

Our main stay, "Peter", not entirely rested from the previous week's hard fought battle, was called on again to exert himself to his utmost in an attempt to beat the Beavers on their own diamond. Another great pitcher's battle was brought to a close, again in the fourteenth inning, this time with Cedarville on the short end of a 3-2 score.

\section{WILBERFORCE}

In the annual Cedar Day battle against Wilberforce, pitchers on both sides were changed in an effort to curb the free hitting opponents, but to no avail. Nevertheless Cedarville proved her diamond supremacy and better generalship, and consequently won her last game of the season, II to 10, to complete a most successful season against extremely stiff competition. 


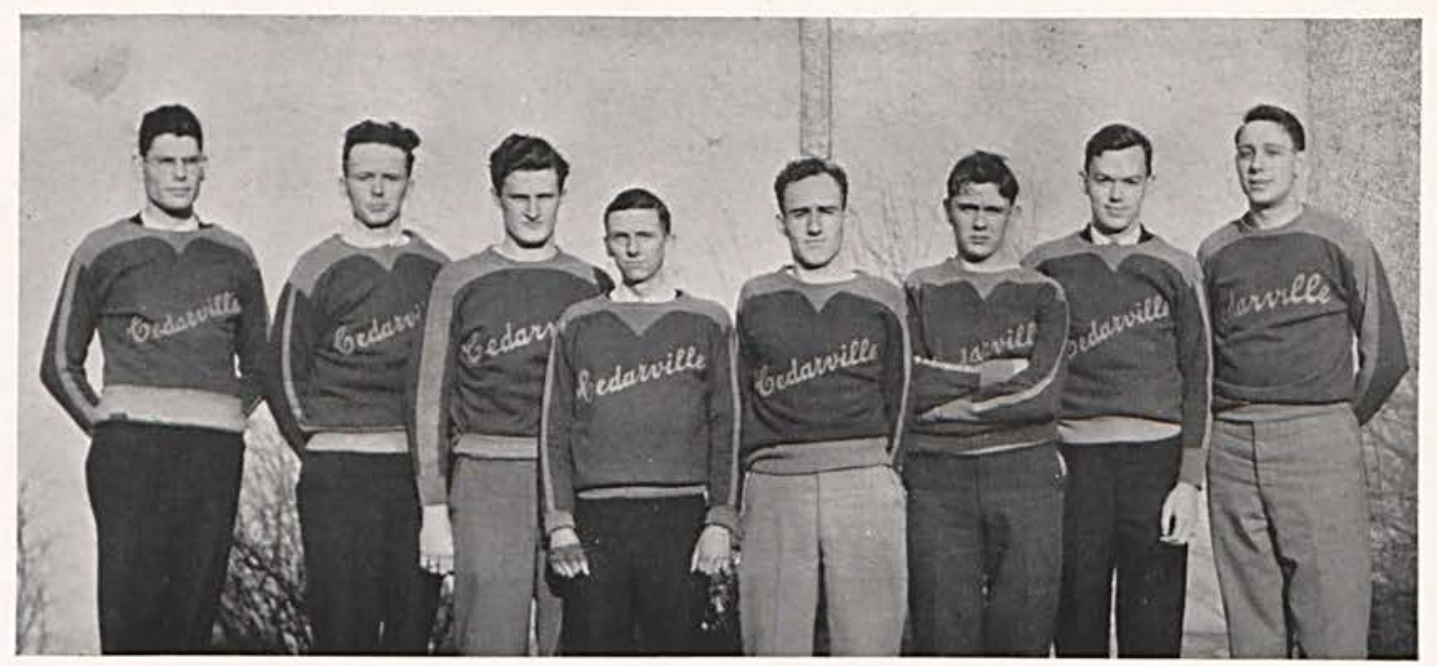

Donaldson, E. Corry, Swaim, W. Waddle, Spencer, Wallace, Kilpatrick, Harriman.

\section{TENNIS '33-'34}

TENNIS CLUB PRESIDENTS OF THE PAST

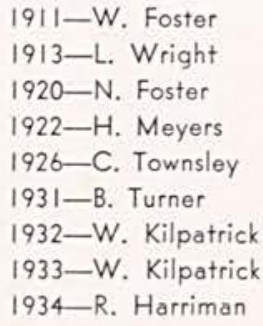

Soon after school opened the tennis club was organized with Robert Harriman as president. The club sponsored a tournament in which men's singles and doubles, women's singles and doubles and mixed doubles were played. The men's singles tournament was especially important because it furnished the chief means of determining the likely candidates for the tennis team to represent Cedarville in the spring intercollegiate matches. Of the men's singles those that survived the opening rounds of play were: Guthrie, Kilpatrick, Swaim, Donaldson, Harriman, Corry, Wallace, and Waddle. Out of these, all were finally eliminated except Kilpatrick and Guthrie, who met in the finals match to decide the tennis championship of the school. These men were almost evenly matched and some fine tennis was the result; however Kilpatrick finally succumbed to the steady offense and the well-placed shots and returns of Mr. Guthrie. The match ended with the score sheet showing this record of sets played: 7-5, 7-5, 6-4.

With Donaldson as his partner, Mr. Guthrie was also successful in the doubles tournament, defeating Kilpatrick and Harriman in a hard fought championship match.

The tennis team which was ably captained by Kilpatrick, met with some stiff competition in the season's schedule in 1932-1933, winding up the season with a clean sweep over Wilmington on Cedar Day. Nevertheless, the team has lined up under the leadership of Harriman another difficult schedule for the spring, meeting Antioch, Bluffton, Otterbein, Wittenberg, Wilberforce, and Wilmington. Mr. Guthrie, who has had broad tennis-playing experience in college and elsewhere, is serving as coach. 


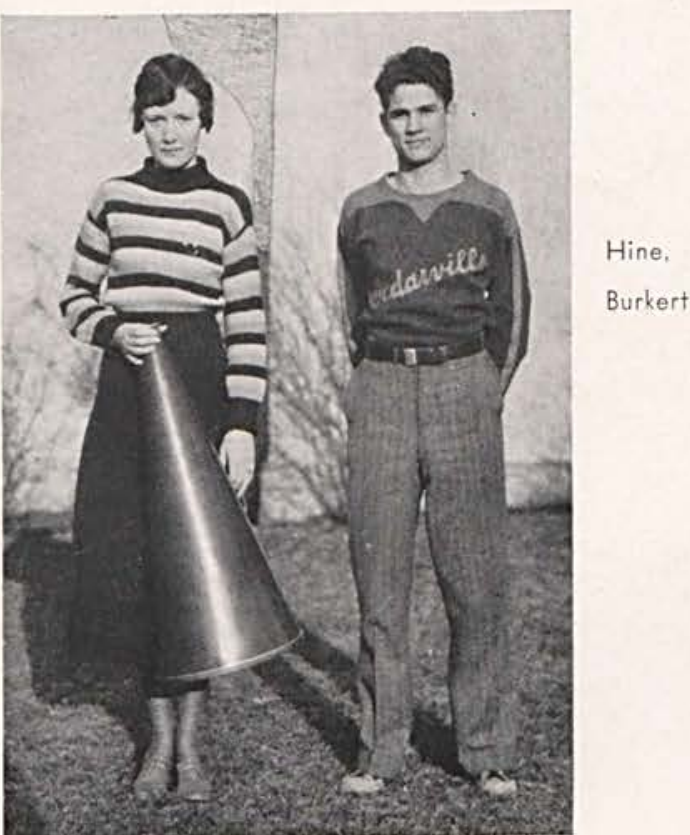

CHEERLEADERS

There are but very few people who realize and appreciate the task that cheerleaders have. Primarily, a cheerleader is selected for his ability to get the student body to respond to his leadership.

Ethel Hine and Donald Burkert were selected by the student body from a large number of nominees, after each nominee had been given an opportunity to display his own talent of leading the student body in noise-making. When the students selected these people for yell leaders, they chose two who were well fitted for the job. "Pally" and "Dutch" are full of pep, and much credit should be given them for their continued efforts and the whole-hearted enthusiasm which they displayed throughout the basketball season.

Our school spirit of the past was revived and spurred to new heights this year, largely due to the excellent work of these two. Since enthusiasm and cooperation is needed for the best results, the cheerleaders can claim much credit for the fine exhibitions of fight and pep our team showed.

\author{
C.E-D.A-R.V-I.L-L.E \\ C-E-D-A-R.V-I-L-L-E \\ C-E-D-A-R-V-I-L-L-E \\ Cedarville, Cedarville, Cedarville \\ $\ldots \ldots \ldots$ \\ Orange and Blue, Fight, Fight \\ Orange and Blue, Fight, Fight \\ Who Fight! You Fight! \\ Orange and Blue, Fight, Fight. \\ ZZZZZZZZZZ \\ $\mathrm{BOOM!}$ \\ Ah........... Cuckoo \\ CEDARVILLE-RAH!

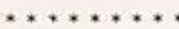 \\ Fight-Team-Fight \\ Fight-Team-Fight \\ Fight-Fight-Fight \\ $* * * * * * * * *$ \\ Fight-fight-fight-fight-fight \\ Fight-Fight-Fight-Fight- \\ Fight \\ FIGHT_FIGHT_FIGHT_FIGHT \\ -FIGHT \\ $* * * * * * * *$ \\ Fight Team. Fight_-Fight Team \\ Fight \\ Fight Fight-Team \\ Fight Team Fight-Fight Team \\ Fight \\ Fight Fight-Team
}




\section{ATHLETIC DIRECTORS OF THE PAST}

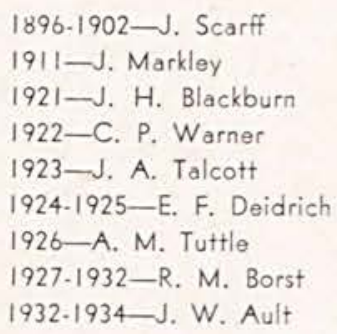

\section{FOOTBALL CAPTAINS OF THE PAST}

\author{
1902-E. Shaw \\ 1922 -W. Riddle \\ 1923-Currie \\ 1924 -W. Taylor \\ 1925-Stoltz \\ 1926 - Stoltz \\ 1927-P. Brown \\ 1928-W. Nagley \\ 1929-R. Jacobs \\ 1931 - J. Stormont \\ 1932 -E. Irons \\ 1933-P. Garlough
}

\section{A WORD FROM COACH AULT}

Cedarville College entered the Northwest Ohio Conference at the beginning of the collegiate athletic season of 1933. The scope of the conference includes basketball, baseball and track. Cedarville College does not sponsor a track team but competes in basketball and baseball.

During the season of 1932-33 the college sponsored teams which participated in seven football games, eighteen basketball games and nine baseball games. In the season of 1933-34 the teams played fifteen basketball games and eight baseball games.

Cedarville College teams are forced to participate against teams drawn from much larger student bodies. In spite of this handicap they are able to win their share of the games.

Athletics is not an end in itself but is only of value in so far as it can contribute to the physical fitness, sportsmanship and character of the athlete. Athletic teams are sometimes looked upon solely as an advertising medium of the school, and the student who participates under these conditions is very apt to think he is rendering the college a service. Ball games and ball teams are a means of advertising a school, but they should never be tolerated for that reason alone. The physical and moral benefit of the student is all the justification any athletic program needs. 

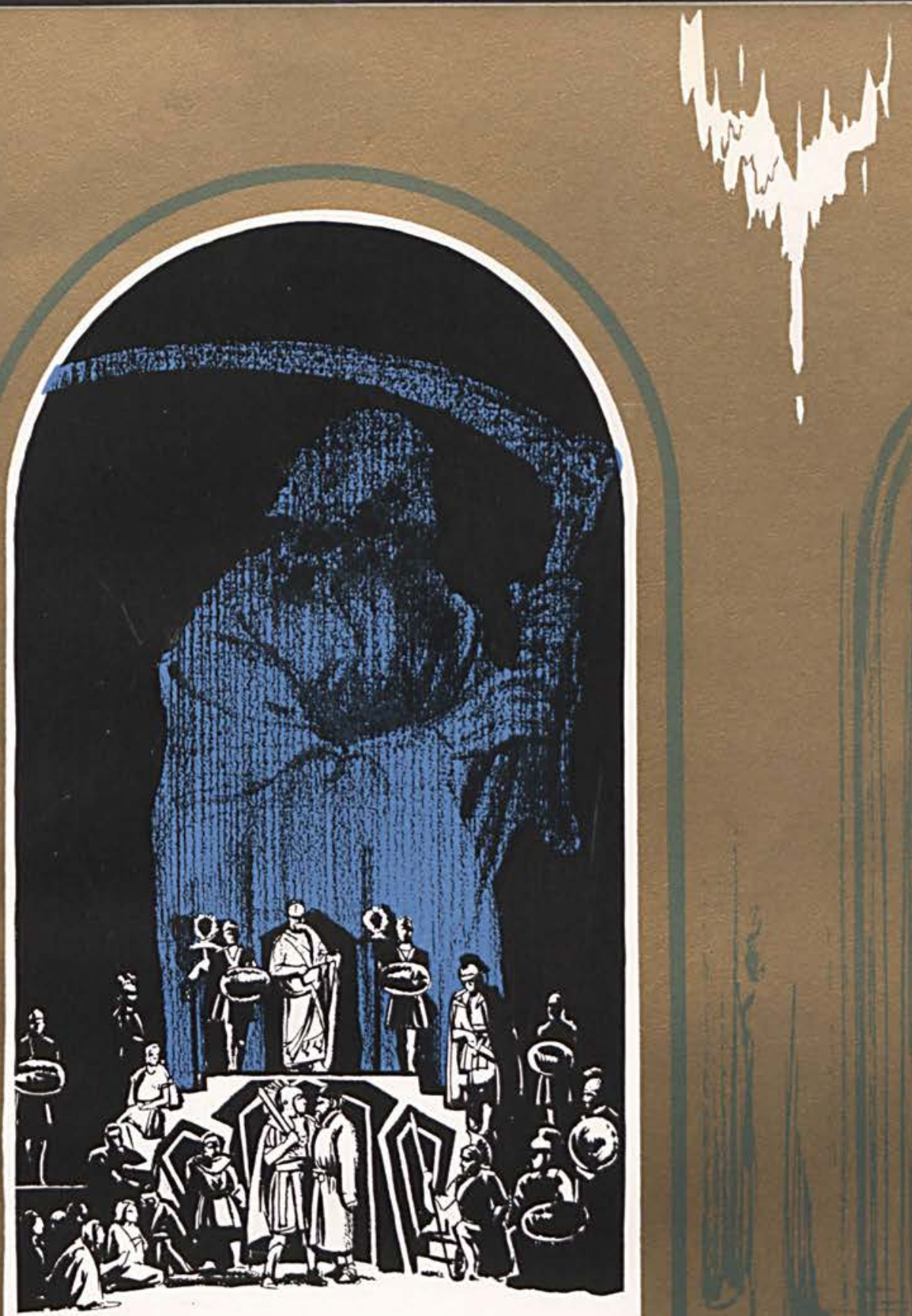

is

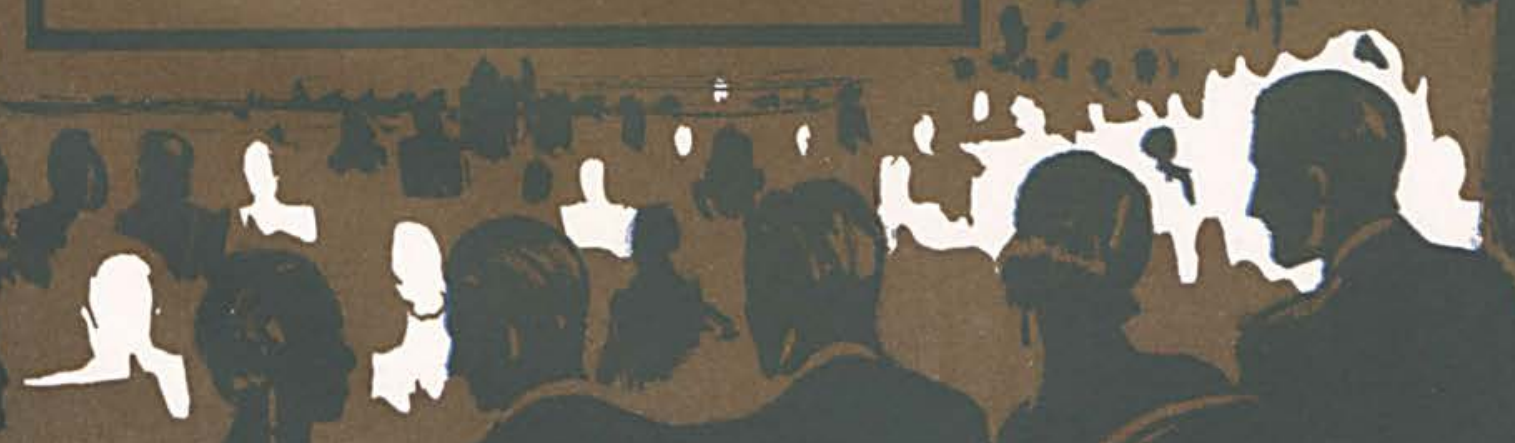

ACT FOUR . . FEATURES 



\section{FEATURES OF 1933-1934}

\section{SENIOR CLASS PLAY, 1933}

The seniors of 1933 presented the four-act play, "Grumpy," in the Opera House, May 31. 1933, under the direction of Glenna Basore. Clyde Hutchison played "Grumpy" with the knack of a real actor. His queer fancies and whims kept everyone on the jump, especially his servant, Ruddock (Garlough). Bob Richards, as Mr. Ernest Heron, was quite interested in Grumpy's granddaughter, Mrs. Virginia Bullivant (Viola Harbaugh). Joe Free, as Mr. Jarvis, was the wolf in sheep's clothing. Dr. Maclaren, the family physician (Charles Spencer) and his good wife (Florence McLaughlin) were frequent callers at Grumpy's home. Keble (Charles Bost) was the doctor's helper. The inseparable Charlies! Susan, the maid, was played by Doris Swaby. Edgar Brigner as Merridew and Herman Scott as Dawson were the other members of the cast. Music was furnished by the college orchestra and the girls' quartet.

\section{CROWN CLUB}

The Cedarville College Crown Club, the college honor society formed in 1920, has grown from a membership of four in that year to one of sixty. In 1933, eight students were added to the ranks of the intelligentsia. Our congratulations are extended to Lois Cultice, Doris Hartman, Clyde Hutchison, Walter Kilpatrick, Regena Smith, Charles Spencer, Doris Swaby, and Ruth West. May the years continue to add to this roster of the C. C. C. C.

\section{JUNIOR-SENIOR BANQUET}

The Juniors of ' 33 conducted the Seniors over hills and through dales to the spacious Garlough homestead near Pitchin, where on May 26, the annual Junior-Senior Banquet was served to about forty-five guests.

We were Indians, just for a night. The tables were decorated with large tepees; canoes served as mint cups; and the programs were miniature tepees.

Walter Kilpatrick was the Medicine Man and served as toastmaster. Each person taking part on the program planned by Glenna Basore was an Indian. "Pat", in his clever way, introduced each Indian with a passage of poetry. "Red" Murray, Big Chief, welcomed the Seniors. The response was made on behalf of the Seniors by "Joe" Free, lagoo. Doris Hartman and Ruth West, Owaissa and Opechee, sang the "Indian Love Song." Professor Hostetler, Kwasind, spoke on the subject "Pogagogams," which is a type of tomahawk. Lois Cultice, Laughing Water, sang two solos, "Red Wing" and "Pale Moon". Dr. McChesney, The Arrow Maker, gave the concluding talk, on "Bows and Arrows." 


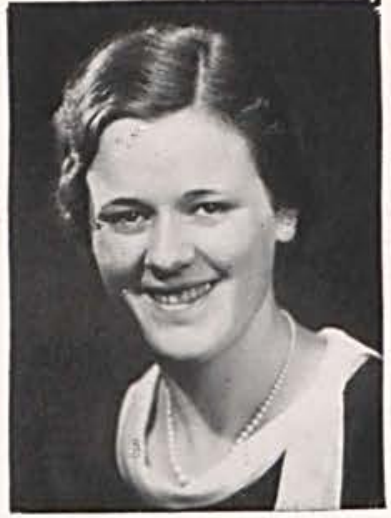

MISS HELEN BAKER, Secretary to the President

\section{SUMMER SCHOOL}

The 1933 summer session of Cedarville College began on June 12 and continued until July 21 . The enrollment of the collegiate division was fifty-eight while that of the elementary training school, maintained in connection with the normal department, was forty-two. At the conclusion of the term, brief commencement exercises were held, with Dr. Tilford, of Xenia, as speaker, and the graduates were presented with their certificates and diplomas by Prof. Hostetler, the director.

The faculty for the summer session was composed of Prof. Hostetler; Miss Carrie M. Rife, Principal of Cedarville High School; Prof. Warner, Superintendent, Bath Township High School, Osborn; Prof. Kuehrmann, and Mrs. R. M. Borst, Cedarville College.

\section{PRESBYTERIAN PARTY}

The Christian Endeavor of the Presbyterian Church entertained the faculty and students on the evening of September II on the lawn of the manse. Various group games were played, after which refreshments were served.

Judging from the appearance of the watermelon and canteloupe served, we all believed them to have found acres of melons growing somewhere in the vicinity.

The evening of fun and frolic was beautifully closed with a friendship circle and a quiet hour.

\section{FRESHMAN WEEK}

Came September, 1933, and with it, forty green and rather timid freshmen, articles of little use other than to please the whims of any passing upperclassman. No task seemed to be too menial or incongruous for a poor freshie to perform.

The powers-that-be at Cedarville College ordained that for one week freshmen should answer any reasonable requests made by the upperclassmen. Freshmen girls were compelled to sing college songs whenever asked and to bring lollypops for upperclassmen's use. The boys were requested to carry the books of those same dear upperclassmen.

In addition, one by one they were familiarized with the country by a committee which took them for rides and came back without them. The vast amount of talent in the illustrious class of ' 37 was disclosed in the chapel on Thursday of Freshman Week when a program was presented by the class. On Friday the freshie girls scrubbed the steps clean with brooms and brushes. This concluded their duties and they became full-fledged members of the student body of C. C.

The frosh boys pushed the bucking machine across the football field, with gentle persuasion from paddles wielded by Junior boys. After this was over freshman week was climaxed when the freshies "dunked" the Sophomores in the annual tug-of-war at Willow Bend.

\section{Y. W. WELCOME TEA}

At the Welcome Tea sponsored by the Y.W.C.A., at the home of the president, Jane West, on September 6th, the girls learned to know each other, and life seemed a little brighter for those who were thinking of friends at home whom they had left to come to college.

A program of music, readings, and speeches was arranged by the program chairman, Miss Basore. Get-acquainted games were played, songs were sung and the social chairman served tea and wafers. At the close of the afternoon a friendship circle was formed to seal the friendships made, with the singing of "Blest Be the Tie That Binds."

Page Fifty-eight 


\section{Y. W. COMMITTAL SERVICE}

A dimly-lighted church, decorated with flowers and ferns, served as a fitting background for the impressive committal service of the Y.W.C.A., given each year in memory of Frances McChesney, the author.

It is a dedication service, and this year forty-four girls pledged themselves to Christian ideals, accepting the blue triangle with its three-fold life.

Jane West, president of the organization this year, led the consecration which closed with a beautiful candlelight recessional, the girls singing "Follow the Gleam." The candles the girls carried are symbolical of the light the Y. W. would have them carry out into the world as they leave the college halls.

\section{METHODIST RECEPTION}

The Epworth League Reception for the college students was held the night of September 19th in the form of a miniature of the Century of Progress Exhibition. Features were an information bureau, Mills' Odditorium, a broadcasting studio, weight guessing, motion pictures of the grounds, Elsie Post's facial treatments, Frances Hutchison's State Building, the Sky Ride, Jane Frame's Transportation Building, and a pageant, "Wings of a Century." After the "tourists" had inspected the grounds, the reception was concluded with a regular "World's Fair" luncheon.

\section{Y. HALLOWE'EN}

When "Bossy", feeling the spirit of the time, took her annual flight to the gym, the air was so full of the spirit that it is said "whole buildings walked", and the time for the college Hallowe'en party had come. Siamese Twins, Japs, Mexicans, hoboes, clowns and "ye ladies of olden times" were among the guests. Potee and Spencer came in one pair of trousers: Dorothy Anderson came as a witch, puzzling many with her No. 9 shoes and rolled socks; Doris Hartman and Jane West came as "my ladee fair" and her "gallante". These were adjudged the prize-winners.

Contests and a true Hallowe'en lunch made the evening a pleasant one. The party this year was conducted by the Y.M.C.A.

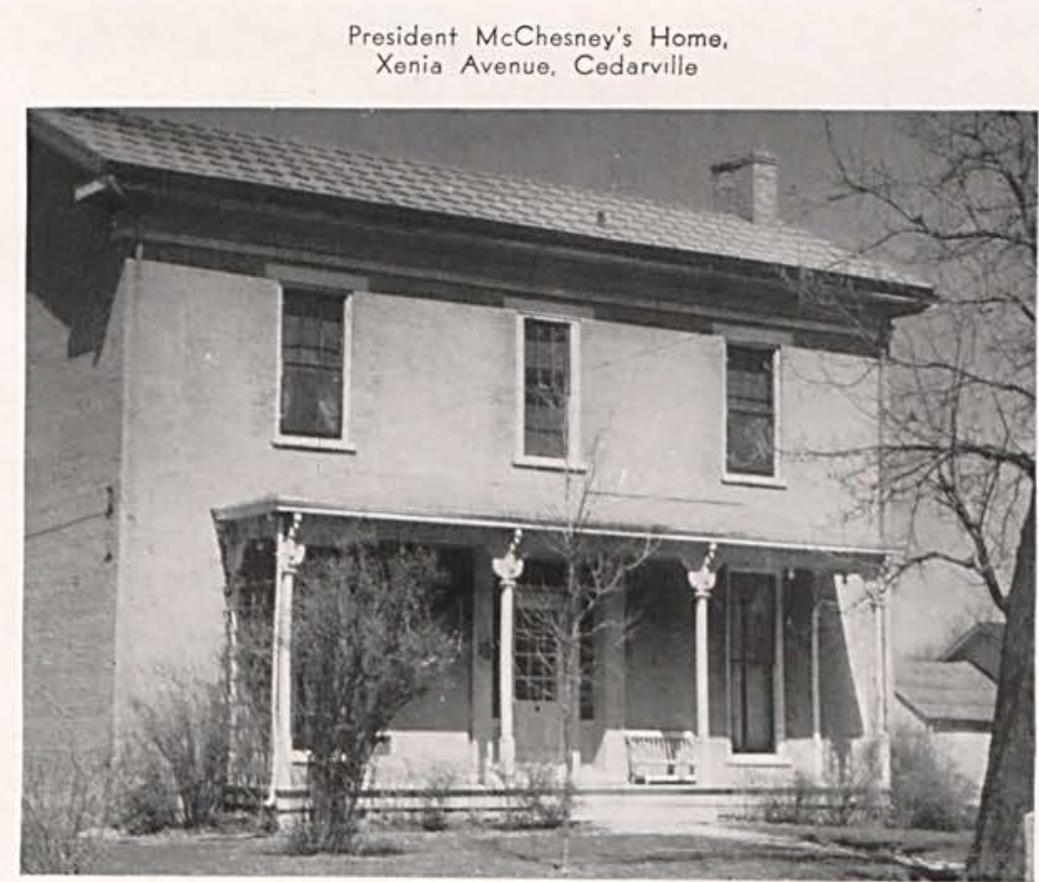




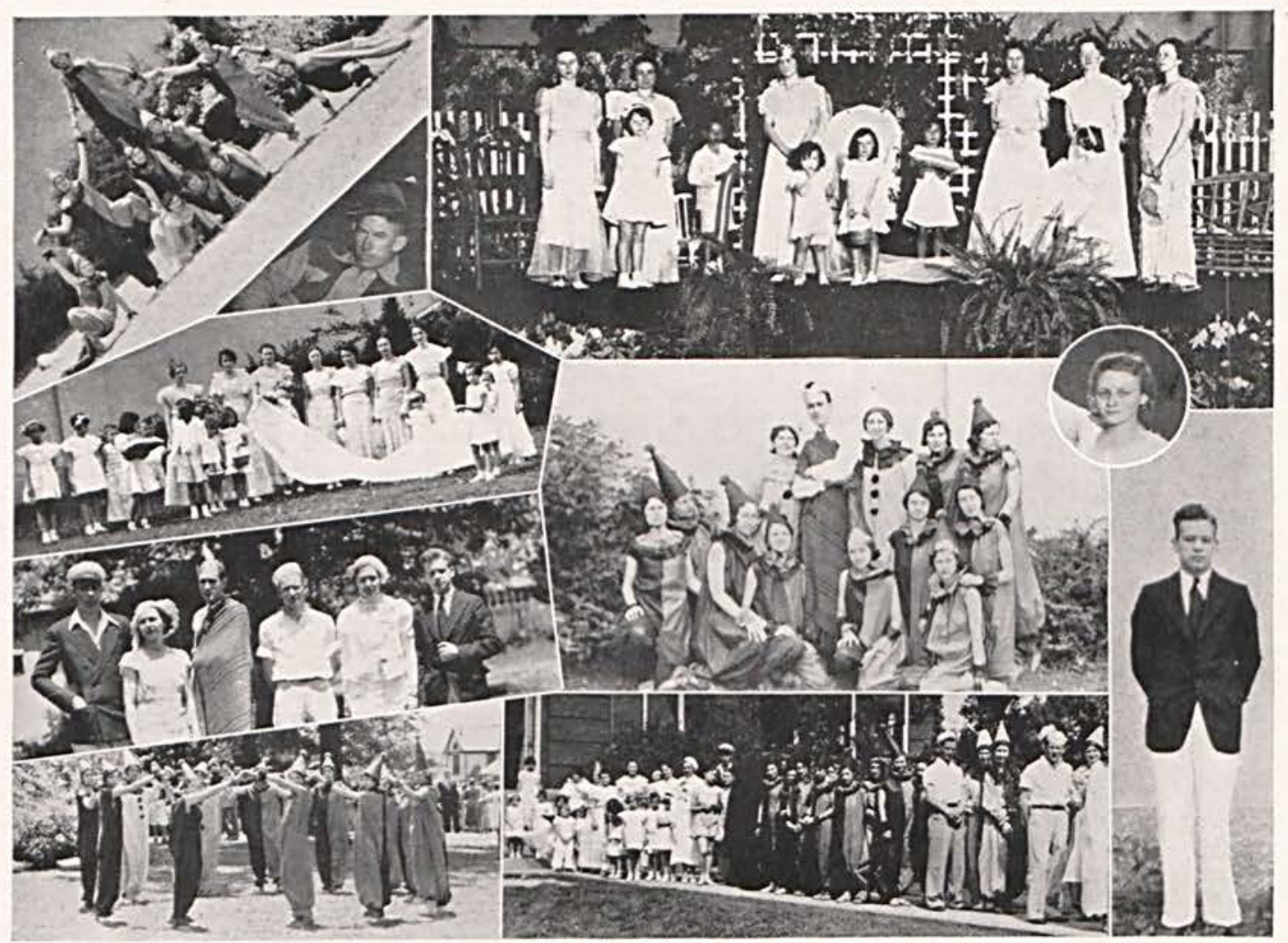

ORATORS AND MAY QUEENS OF THE PAST

$1911-W$. P. Harriman

1914 -C. Ross, M. Bird

1915-M. Rife, M. Corry

1916 - J. Chestnut, D. Collins

1917 - ..... R. Ramsey

1918 - ...... H. Oglesbee

1919-M. Creswell. M. Gilkey

1920 - E. Bradfute

$1921-N$. Thorn, H. Stewart

1923 - ...... F. Smith

1924 -..... L. Caskey

1925 -...... L. Cummings

1926 -Dutton, L. Hastings

1927-D. Kennedy, M. McKay

1928-E. Wones, M. Webster

1929-B. Fleming, M. Chandler

1930-H. Main, L. Tanner

1931-R. Collins, S. Rumbaugh

1932-M. Hostetler, R. Douthett

1933 -C. Hutchison, D. Swaby

$1934-$ W. Kilpatrick, R. Smith

\section{CEDAR DAY, 1933}

On Thursday, June 1, a record crowd gathered at the Gym for the annual Cedar Day celebration. Attended by Wilda Auld, Nina Stevenson, Regena Smith, Florence McLaughlin, and Viola Harbaugh, Doris Swaby made a very charming queen of the celebration. She was crowned by Rachel Douthett, queen of ' 32 .

Each class presented a stunt and the girls' physical education class built pyramids. The central feature of the program was an operetta entitled "The Isle of Chance." This was followed by the Cedar Day Oration, "Knowledge is Power," delivered by Clyde Hutchison.

Miss Regena Smith directed this program and was assisted by members of the student body and the faculty. 


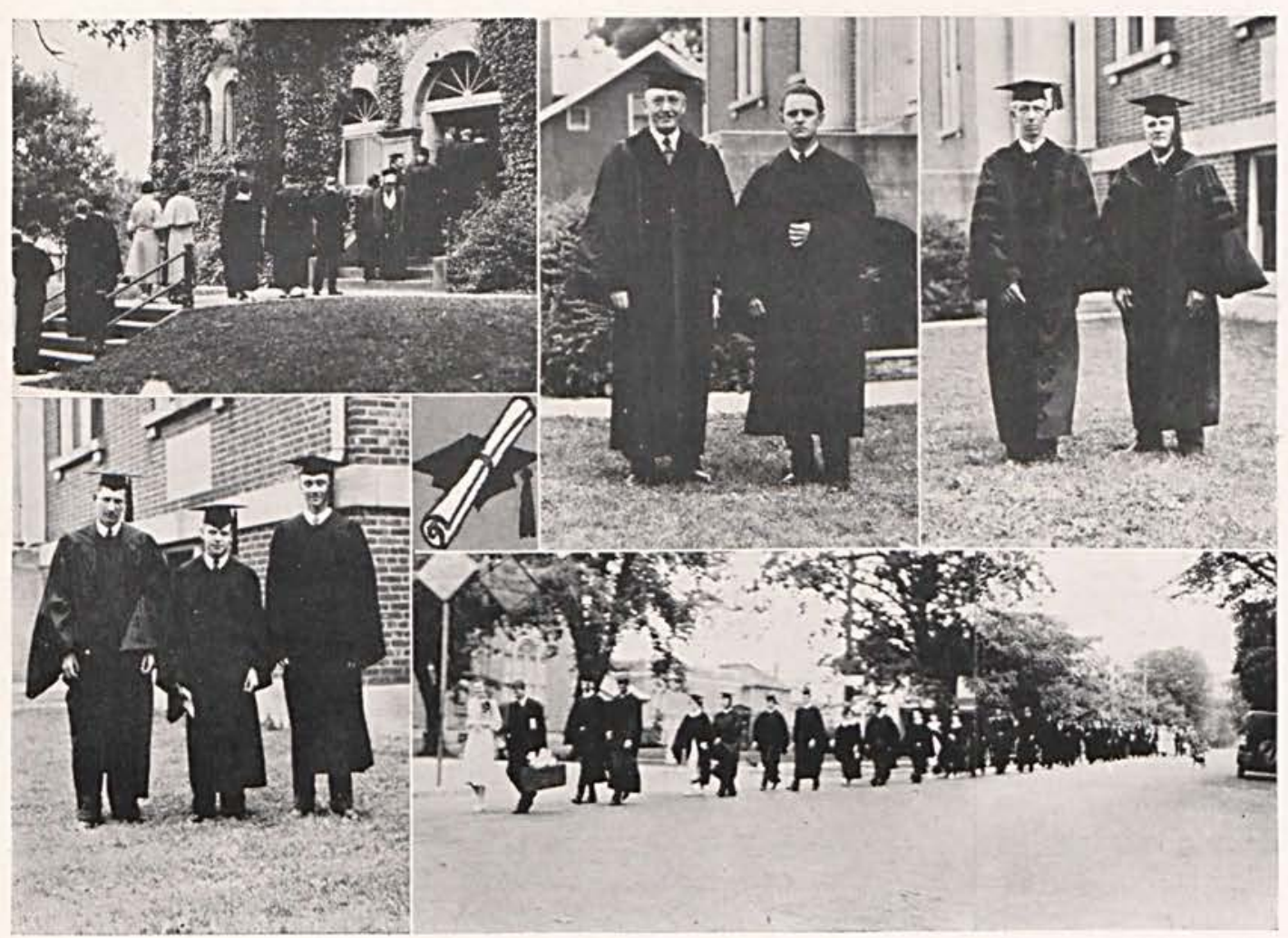

\section{COMMENCEMENT, 1933}

The thirty-seventh annual commencement of Cedarville College was held Monday, June 5, at the First Presbyterian Church.

The speaker for the occasion was the Hon. Mason Douglass, Judge of the Common Pleas Court of Montgomery County, Ohio. He delivered a splendid address in a manner which will not soon be forgotten.

The guest organist was Dr. Edward Eigenshenk, organist of the Second Presbyterian Church, Chicago, Illinois, who received his Doctor of Music degree from Cedarville in 1932. His playing was fascinating, showing exceptional ability and comprehension of music.

The degree of Bachelor of Arts was conferred upon twelve students; five others received the degree of Bachelor of Science in Education; and two able ministers were honored with the degree of Doctor of Divinity.

Honors were conferred on eleven students; eight Juniors and Seniors were elected to the Cedarville College Crown Club for high scholastic standing, and three graduates, Charles Bost, Clyde Hutchison, and Charles Spencer, received their degrees "Magna Cum Laude."

The exercises were closed with the invitation to return next year for the celebration of the Fortieth Anniversary of the founding of Cedarville College.
COMMENCEMENT SPEAKERS OF THE PAST

1897-Rev. Charles Goss

1906-Rev. Robert Watson, Ph. D.

1910-W. O. Thompson

1918-Gov. Frank B. Willis

1922-Rev. J. McQuilken, D. D.

1923-Homer Henderson and Wilbur D. Nesbit

1924-Edgar A. Guest

1925-Bishop McDowell

1926-Congressman Clyde A. Kelly

1927-Bishop Henderson

1928-Judge Florence E. Allen

1929-Bishop E. H. Hughes

1930-Dr. Percival Barker

1931-Dr. W. L. McEwan

1932-Dr. A. G. McLennon

1933-Judge Mason Douglas

1934-Dr. M. Earle Collins 


\section{MEN'S BIBLE READING CONTEST}

The annual men's Bible Reading Contest was held in the Presbyterian Church November 12, 1933, before a capacity audience. In awarding the prizes Dean Steele did not express his regrets that there were not prizes for all contestants but instead presented each of the twelve with a pocket testament. This year the fifteen dollar prize money annually offered by Dr. C. M. Ritchie was divided among five readers instead of three as was the custom in past years. The winners in the order in which they placed were Paul Gordon, Walter Kilpatrick, Homer Murray, Franklin Trubee and Donald Burkert.

\section{"BIG BUSINESS"}

The Cedrus play proved a riot of laughter, and was well presented. We shall never forget W. B. McCallister, as Battling Malone, and the serious trouble he had with his liver. Nor shall we forget his wife, Lizzie (Doris Hartman) the scrub woman. The leading man was played by Bud Chamberlain and (though not true to form) how he did dislike women!

We must not omit, in looking over the line-up, to mention Dorotha Corry as the fat cousin from the city-she certainly had a rounded outlook on life! Eleanor Bull, one of the office girls, should make demonstrations for a chewing gum factory. Carma Hostetler, the other half of the office force, was, as usual, quiet but affectionate.

Tindall and his sister, Jane West, carried out plans which meant war to the finish. She certainly knows how to get her man! Bob Ross, a renting agent, was quite a schemer while Harriet Ritenour, the rich aunt, and her physician, Lois Cultice, climaxed the schemes.

It was a good play-thanks to Miss Basore, who directed it.

\section{STYLE SHOW}

Unique and fascinating was the Style Show sponsored by the Y.W.C.A. at the Gym on the evening of March 2, 1934. An interesting program was arranged to fit the occasion and those attending were convinced that it was one of the most interesting entertainments of its type that they had ever seen.

Mrs. Heintz as "mistress of ceremonies" announced the program and, with a verse of poetry which she "ist made up herself", described the dresses worn by each girl taking part. The following program was presented: Cedar Needles Quartet, singing "A Little Song of Long Ago" and "Grandmother's Garden"; Portrait Sketch presented by Jane West and Nine Stevenson; little Clara Galloway sang "The Old Spinning Wheel"; the Orange and Blue Serenaders sang "In Those Good Old Times". "The Mechanical Jane", a short sketch, was enacted by Doris Hartman, Lois Cultice and Glenna Basore. A musical skit, "Hats", was presented by the double quartet. The final number was the picturesque Parade of Wedding Gowns dating from 1850 to the present time.

A quilt display also drew many "ahs and ohs", there being coverlets of old and quilts of modernistic design. The show was a decided success, thanks to all who helped make it so. 


\section{MOCK WEDDING}

Although the boys were not yet engaged in minstrel practice, or out-of-town on a baseball trip, the Y. W. did have the Mock Wedding on the evening of March 16, at the home of Mrs. S. C. Wright.

Preceding the ceremony, Mrs. Work and Anna Jane Wham presented a short musical program. Miss Wham sang "O Promise Me" and "I Love You Truly". Mrs. Work played "To a Wild Rose" and Lohengrin's "Wedding March" from Wagner. The handsome groom, Mr. R. Smith, with his best man, Mr. N. Stevenson, followed Rev. Basore into the room.

The bride Lois Cultice, with her father, Mr. E. Robe, and her attendants, descended the wide stairway. The bridesmaids, Misses Bull, Watkins, Hartman, and Pyles, were dressed in pink, with shoulder corsages of sweet peas. The Maid of Honor, Miss Jane West, was also dressed in pink and wore a shoulder corsage of sweet peas.

The flower girl, Miss Kimble, scattered rose petals in the path of the bride. Miss Kimble wore a dainty yellow dress with white accessories.

Master Mary Linton carried the ring on a satin pillow.

Ushers were Messrs. Anderson, Ritenour, C. Brill and Mount.

You'll have to admit, boys, that we put it over on you. A toast for Carolyn Brill, the Bride of ' 35.

\section{FACULTY RECEPTION, 1933}

At the invitation of the faculty, the student body trooped to the Alford Gymnasium on the evening of June 1, 1933, to enjoy the annual faculty reception. A program consisting of short speeches and musical selections by the various college musical organizations, under Mrs. Work's direction, was presented to the audience. After the formal program, group games were played, and the students and faculty joined in singing college songs. Refreshments were served, with Miss Angevine at her traditional place behind the punch bowl for the last time.

\section{"BLARNEY STREET"}

The Junior Class presented the Irish comedy, "Blarney Street," at the Opera House on March 22.

The action of the play took place on the porches of the Breen-Flanagan duplex. The members of the Breen family were Pat (Bob Harriman); Maggie, his wife (Eleanor Bull); and Rosie, their daughter (Dorothy Lunsford). The members of the Flanagan family were Mike (Arthur Donaldson): Bridget, his wife, afflicted with tumors (Carrie Mount): and their son Dan (Ralph Tindall). Levi Levinsky, a Jew, (William Waddle), tried to buy the business of Breen and Flanagan. Nora O'Leary (Maxine Bennett) kept members of both households informed of the happenings about town. The furniture dealer, (Paul Rife), made life miserable for Mrs. Breen, and the milkmen (Gilbert Christian and Eugene Spencer) interrupted a lasting "good-morning." The stage manager, Carl Ferguson, and stage director, Carolyn Brill, deserve much credit for the stage setting.

Though these two families lived side by side and though the son and daughter were in love with each other, they fought like cats and dogs. The quarreling was climaxed by a tugof-war in which the members of both families took part. But after they thought themselves rich and found themselves poor, they made up and all went well.

The Wilberforce Male Chorus added to the enjoyment of the evening by singing several numbers as only they can sing. The play was directed by Miss Basore. 


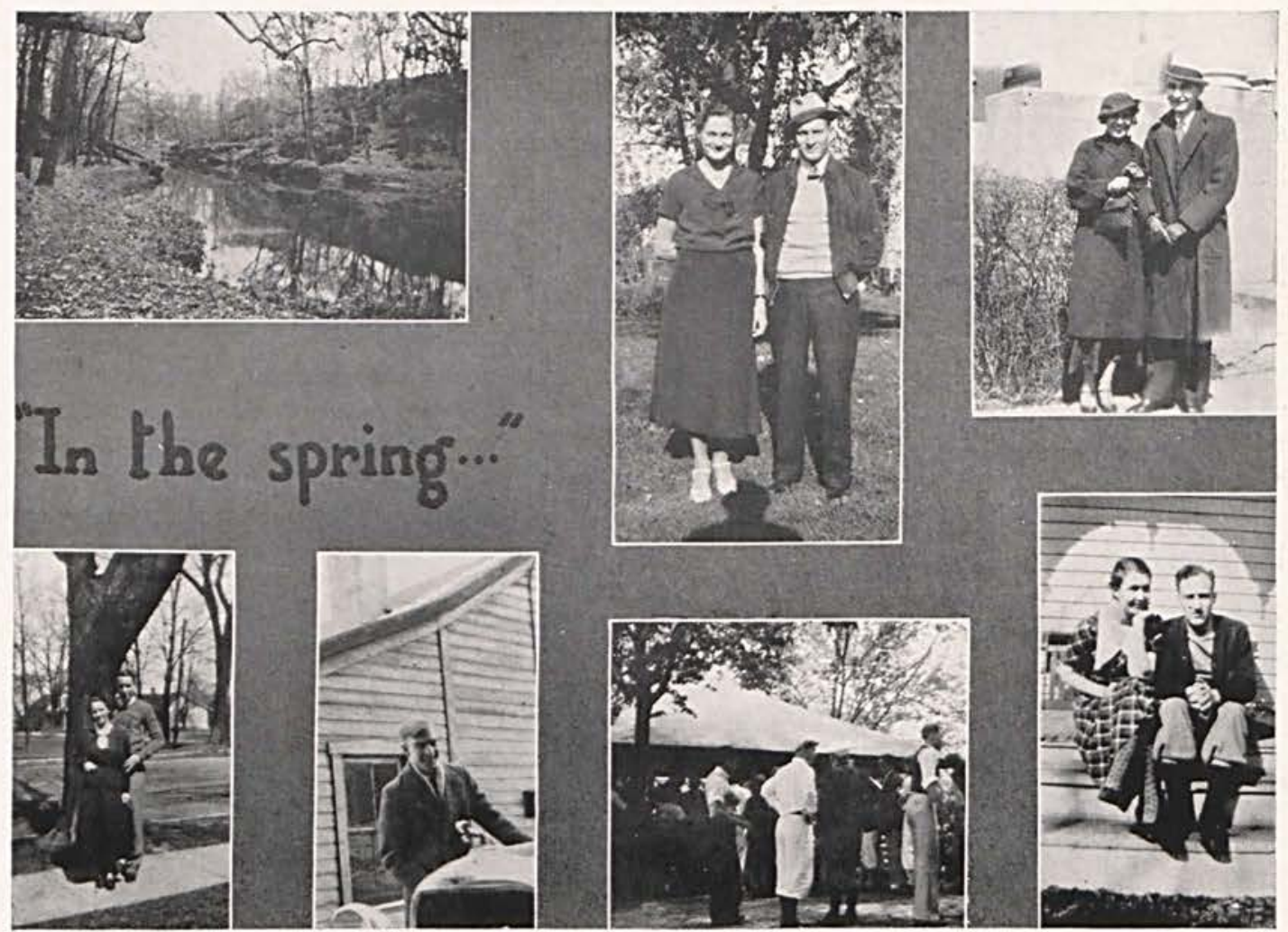

\section{HOMECOMING BANQUET}

The annual Homecoming Banquet was held at the Alford Memorial Gymnasium on the evening of February 3, 1934. Dinner was served by the Ladies' Advisory Board to about two hundred-fifty guests, and oh! the delicious food they served! The music department of the college presented a short program of classical music following the dinner. The Yellow Jackets then met Rio Grande in a fast, hard-fought game with three overtime periods. The crowd cheered the boys on until they finally came through with the laurels, winning by a score of 44 to 43 .

\section{Y. M. MINSTREL.}

April 12 witnessed the biennial Y. M. Minstrel at the Opera House. The curtain rose to the accompaniment of that old favorite "Dinah", played by Duffy's orchestra, and sung by the "en-tire company." After the order of "Gentlemen, be seated" had been sounded, it was quite evident that the interlocutor. Mr. Johnson, (alias Art Donaldson) was in for a hectic evening at the hands of those stellar end men. Gideon, Snowball, Midnight, Deacon Jones, Nimrod and Curly. Snowball and Midnight kept the audience well entertained all evening as they payed with their "galloping dominoes" and oversized razor. The musical part of the program was well presented by the chorus, college men's quartet, with solos by several of the end men and "chorusteers." The program was augmented by specialty numbers on the part of Midnight (Christian), Ralph Bull. and Joe Peak, who gave an excellent impersonation of Harry Lauder. Mr. Duffy directed the show, with Walter Linton handling the duties of business manager very capably. 


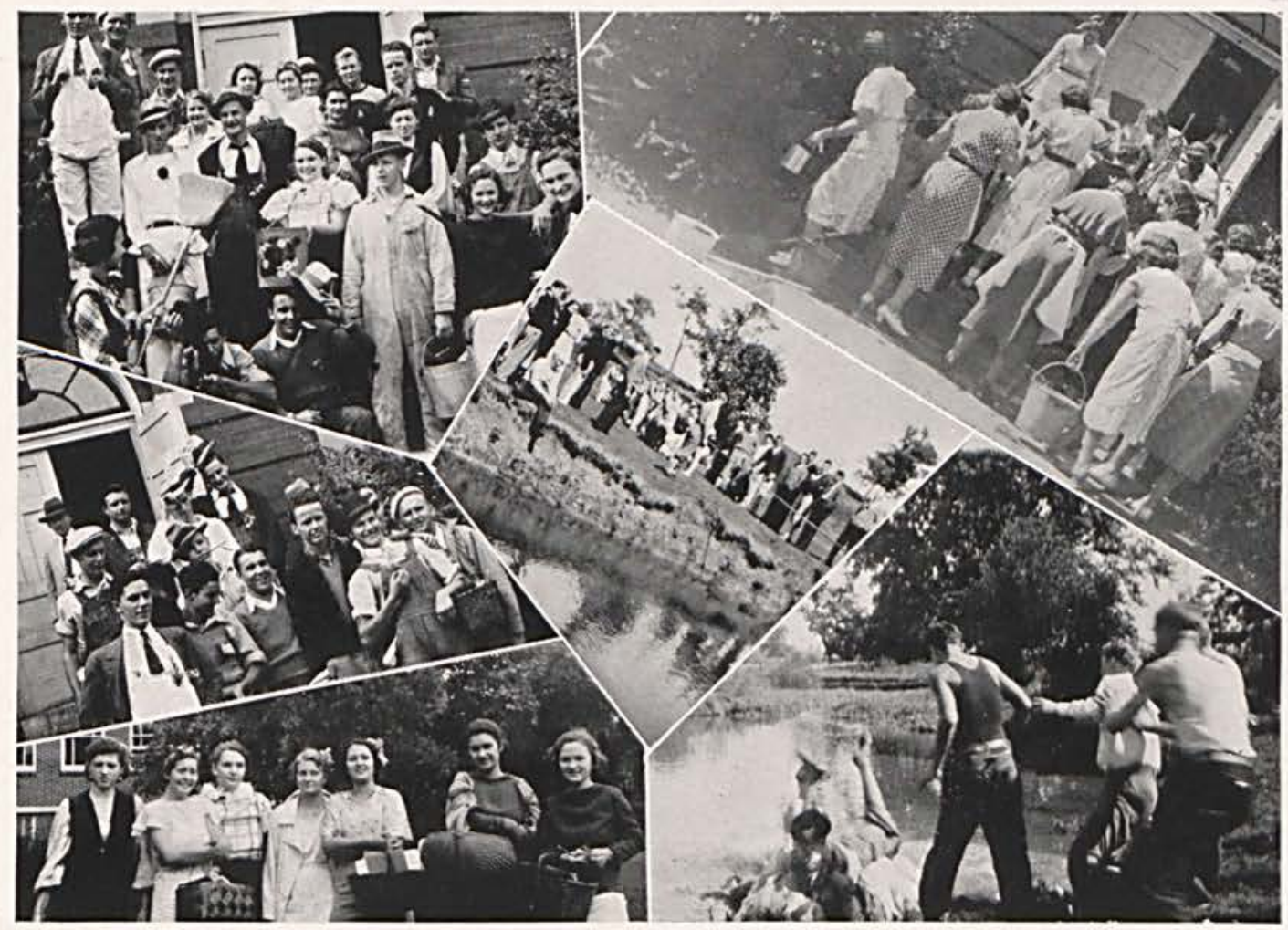

\section{COACH'S RECEPTION}

When Coach Ault pleasantly surprised the students of Cedarville College by bringing a wife into our midst, the students decided to ring the wedding bells again.

The gym was transformed into a fairy bower with the aid of crepe paper, lattice, and ferns. After Coach and his wife led the grand march, an interesting program was presented. Professor Steele gave the couple some sound advice, including the kind of car to buy. The girls' quartets sang: Miss Basore gave two readings, and Eleanor Bull played two violin solos. "Red" Murray, on behalf of students and faculty, presented the couple with an electric waffle iron.

After refreshments had been served, the students sang "Those Wedding Bells Are Breaking Up That Old Gang of Mine"; then we had a good, "old-fashioned" belling, taking Coach and Coachess for a nice long buggy ride.

\section{GIRLS' BIBLE READING CONTEST}

The annual Girls' Bible Reading Contest was held in the First Presbyterian Church, April 8. Fifteen girls took part, each reading well and interpreting her passage in a manner that showed understanding.

Prizes, offered through the generosity of Miss Margaret B. Rife, were awarded to: Miss Esther Waddle, first, who read Revelations 22; Miss Mary Linton, second, who read Matthew 7: Miss Doris Hartman, third, who read Luke 10: 17-37; Miss Jane West, fourth, who read Matthew 6: 19-34: Miss Beatrice Pyles, fifth, who read Matthew 28.

Music was furnished by the Girls' Glee Club and the College Male Quartet. 


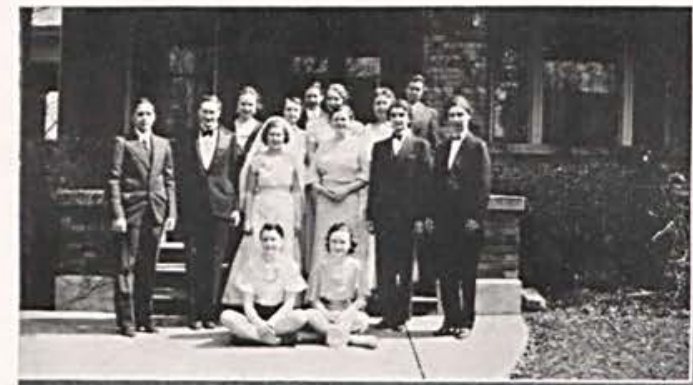

Mock Wedding

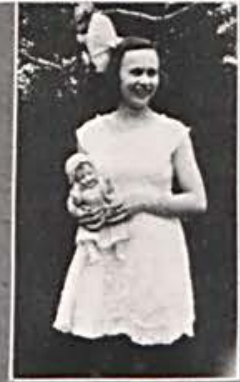

Kid Day

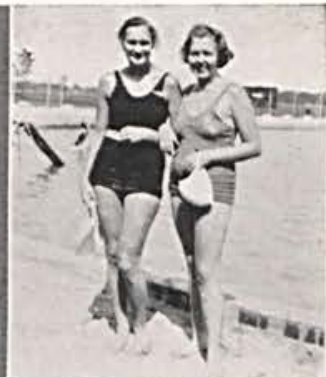

Summer - Ahli
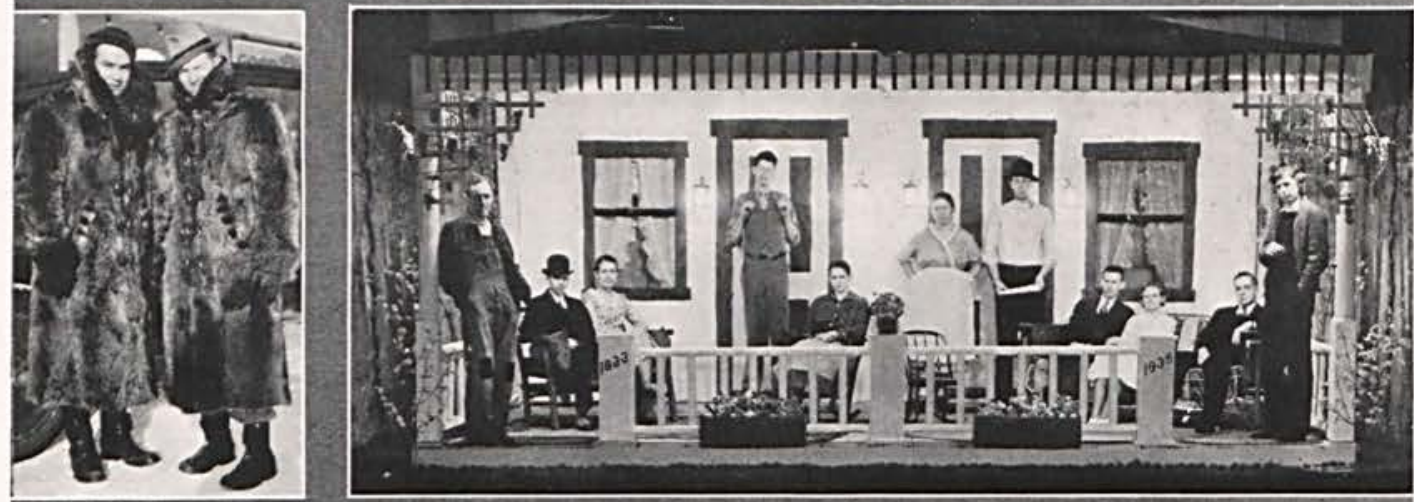

BLARNEY STREET

\section{Y. W. CHRISTMAS PARTY}

At the Y. W. Christmas party, that mysterious "phantom sister", who has been fulfilling every desire and need you may have, becomes a reality. Those lovely gifts and kind deeds! Those pleasant surprises left on the doorstep or in some hidden nook! My! How guilty you feel when you find you have confessed your suspicions to your own secret pal!

The Christmas party this year was held at the home of Eleanor Bull. As chairman of the decorating committee, Eleanor had transformed the house into a fairyland of twinkling lights and greens. Miss Basore, as chairman of the program committee, drove dull care away and filled the evening with fun and merriment.

To top the evening, refreshments were served-each tray bearing a lighted candle. A toast to Mrs. Bull and Eleanor for their hospitality!

\section{PRESIDENT'S RECEPTION}

At the invitation of Dr. and Mrs. McChesney the students and faculty gathered at the presidential mansion on Monday evening, May I. From 7:30 until 9:30 a general social hour was enjoyed by all, after which delicious refreshments were served by Mrs. McChesney and her assistants. After the refreshments the guests joined voices in singing college and popular numbers with Eleanor Bull officiating at the piano. With many thanks to the gracious host and hostess for an enjoyable evening the company took their leave. 


\section{CEDARVILLE COLLEGE}

GET A COLLEGE TRAINING

The times demand it.

The results justify it.

\section{COME TO CEDARVILLE COLLEGE}

The location is healthful and beautiful.

The opportunities are fine and inspiring.

The courses are complete and modern.

The influences are safe and helpful.

The expenses are lower than at many other places.

The students are possessed of high ideals and practice them.

The Faculty is experienced and thoroughly trained.

THE COLLEGE is recognized by the Department of Public Education of the State of Ohio, and by the leading universities.

IN CEDARVILLE COLLEGE you can get preparation for any pursuit in life.

A large Freshman class is to enroll in September. The prospects for a record-breaking attendance are splendid.

FORTY-FIRST YEAR OPENS SEPTEMBER 5, 1934

For catalogue and further particulars, address

W. R. McCHESNEY, Ph. D., D. D., PRESIDENT

CEDARVILLE, OHIO 
FORTIETH ANNIVERSARY

\section{C. CALENDAR, 1933 and 1934}

Sept. 6. Opening chapel exercises. Y.W.C.A. Tea at West's.

Sept. 7. Mixer at Gym. Georgia and Jock Gossip contest winners.

Sept. 10. Convocation Services at Church.

Sept. 11. Presbyterian Reception on Rev. Guthrie's lawn. The boys have another party (watermelon) back of the College.

Sept. 13. Watermelon feed at Creswell's-watermelons and more watermelons!

Sept. 18. Girls' gym class turned into an imaginary swimming meet. Zoology lab starts.

Sept. 19. Cedarville College students attend the Epworth League World's Fair.

Sept. 20. Y. W. and Y. M. cabinet meeting at West's. Student Council and school paper organized.

Sept. 25. Practice teachers start practicing! Shaky legs!

Sept. 27. Today, the "dumb" fresh-men look dumber.

Sept. 28. Program by the freshmen. Are you still blushing, Johnny M.? Some rides.

Sept. 29. Annual "slay" ride, step scrubbing. Freshies turn tables in tug-of-war.

\section{THE FARMERS \& TRADERS BANK}

ESTABLISHED 1867-INCORPORATED 1922

JAMESTOWN, OHIO

Page Sixty-eight 


\title{
CROUSE'S GROCERY STORE
}

\author{
Fruit - Meat - Vegetables \\ "With our compliments to the 1934 Cedrus"
}

CEDARVILLE

PHONE-40

$\mathrm{OHIO}$

Oct. 3. Big feed at the Gun Club in honor of the Freshmen. Snaky snake dance.

Oct. 4. Joe Waddle "hides out". No ride for Joe.

Oct. 5. What happened to the student council?

Oct. 6. Red has his nose cleaned out.

Oct. 7. New York Giants win the World Series. So does Buehler!

Oct. 9. Frosh feed. Harris beats Waddle.

Oct. 12. Y.W.C.A. Committal Services.

Oct. 25. Kid party at Steele's. Suckers ' $n$ ' everything!

Oct. 26. Kenfield shoots his eyes around the room.

Oct. 30. Literary Meeting. Kenfield's car on college steps! Hartman's cow in gym.

\section{JEAN PATTON}

FOR D

SALES AND SERVICE

Phone-213 FI3 Cedarville

HARDWARE

Cedarville

\section{ROOFING AND REPAIR WORK}

Phone $2-128$
TIN SHOP

Ohio

\section{E. MASTERS} GROCERY AND MEAT MARKET 


\section{$\mathrm{C} \mathrm{O} \mathrm{A} \mathrm{L}$}

FOR THE BEST HIGH GRADE COAL AT THE RIGHT PRICE and

WHEN YOU WANT IT

SEE ME

\section{L. McGUINN}

Phone 3

Cedarville, $\mathrm{O}$.

\section{RENTFROW'S}

Finger Waving

Marcelling

Permanents

Call for Appointment

BEAUTY PARLOR

BARBER SHOP

STANDARD

\section{lce Cream}

Goodness! How you'll like it.

Buy from

\section{Richard's Drug Store}

Delicious

Nourishing

SPRINGFIELD PURITY DAIRY

Springfield, Ohio

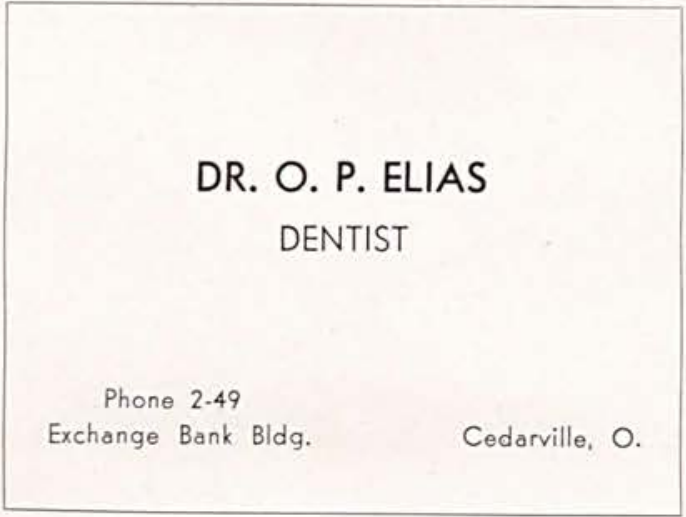

RECO

\section{SPORTING GOODS}

for

Boys and Girls

Baseball - - Softball

Tennis - - Golf

Rackets Restrung

Fishing Tackle

The Reco Store

16 W. High St. Springfield, O. 


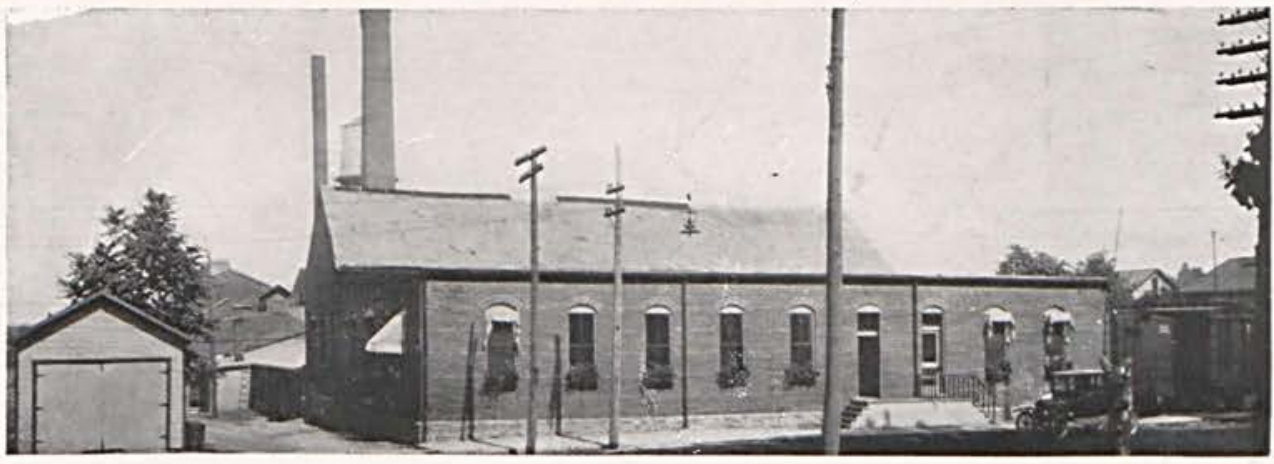

\section{THE}

HAGAR STRAWBOARD

\& PAPER COMPANY

CEDARVILLE, OHIO

FINE STRAW BOARD

FOR CORRUGATING 


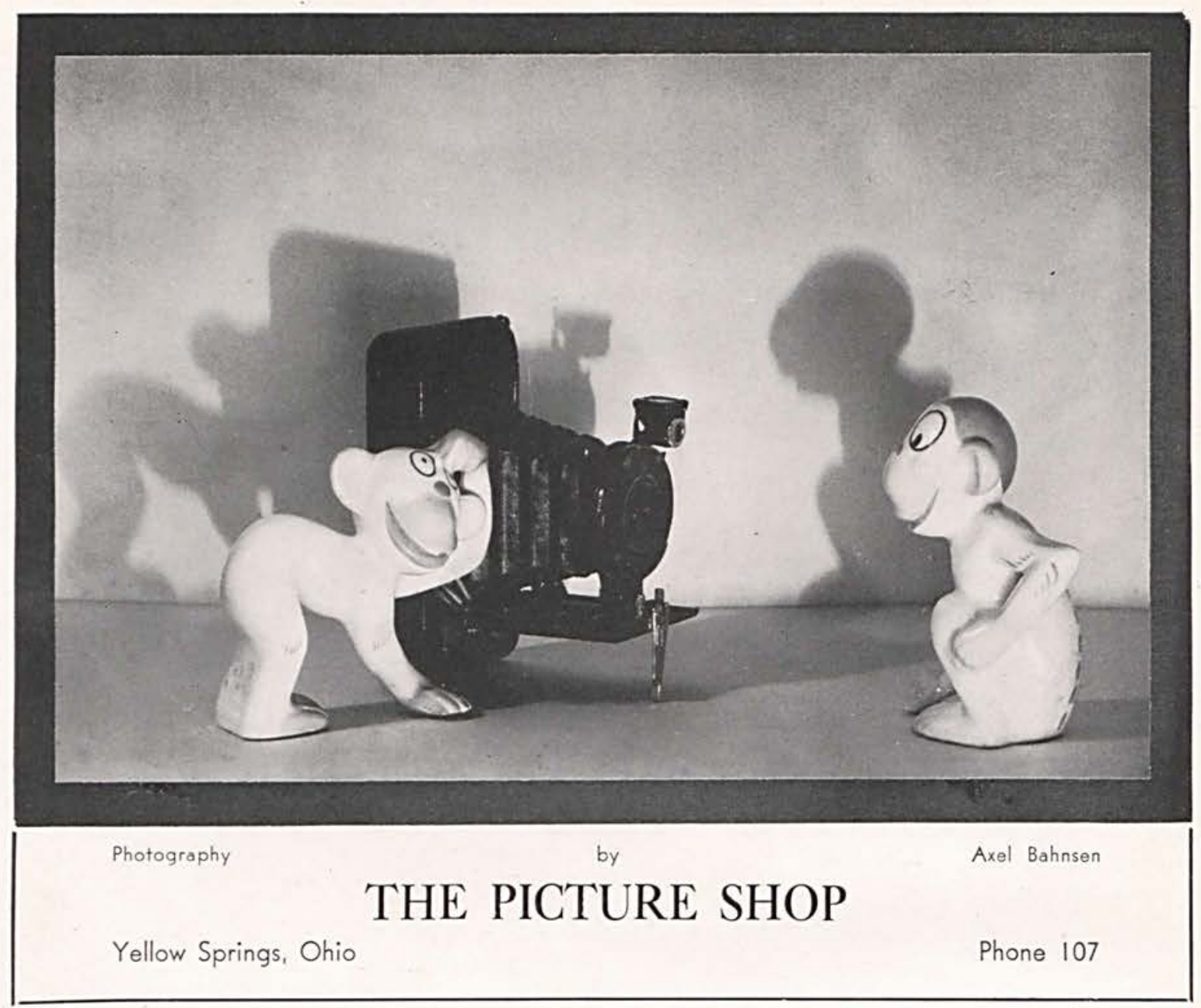

Nov. I. Soph feed. Why feed Ault hay?

Nov. 4. "Ye Ole Jail House" party.

Nov. 7. Y. girls sell tags.

Nov. 8. Kenny Little, mayor. Cedarville remains dry.

Nov. 12. Men's Bible Reading Contest. Gordon, the winner.

Nov. 19. School days at Literary. College paper makes its debut.

Nov. 14. J. Mills takes roasting about John Fudge's dishwasher.

Nov. 15. Y. W. Style Show under the direction of Mlle. Stevenson.

Nov. 17. Liquid air demonstration at H. S.

Nov. 20. Hannibal crosses the Alps in Latin class.

Nov. 21. Lost, two incisors. Return to Bud Chamberlain.

Nov. 24. "Iron-Works" starts again.

Nov. 27. Second edition of Whispering Cedars.

Nov. 28. Cedrus play, "Big Business."

Nov. 29. Baskets distributed to poor. Thanksgiving vacation.

Dec. 2. "Jimmy and Sally". Red and Russ held up by new patrolman.

Dec. 5. Rev. Hill does a Thurston by pulling out umbrellas, books, etc., from the piano. Freshmen feed at Charleston. Spencer runs a race with Bennett. 

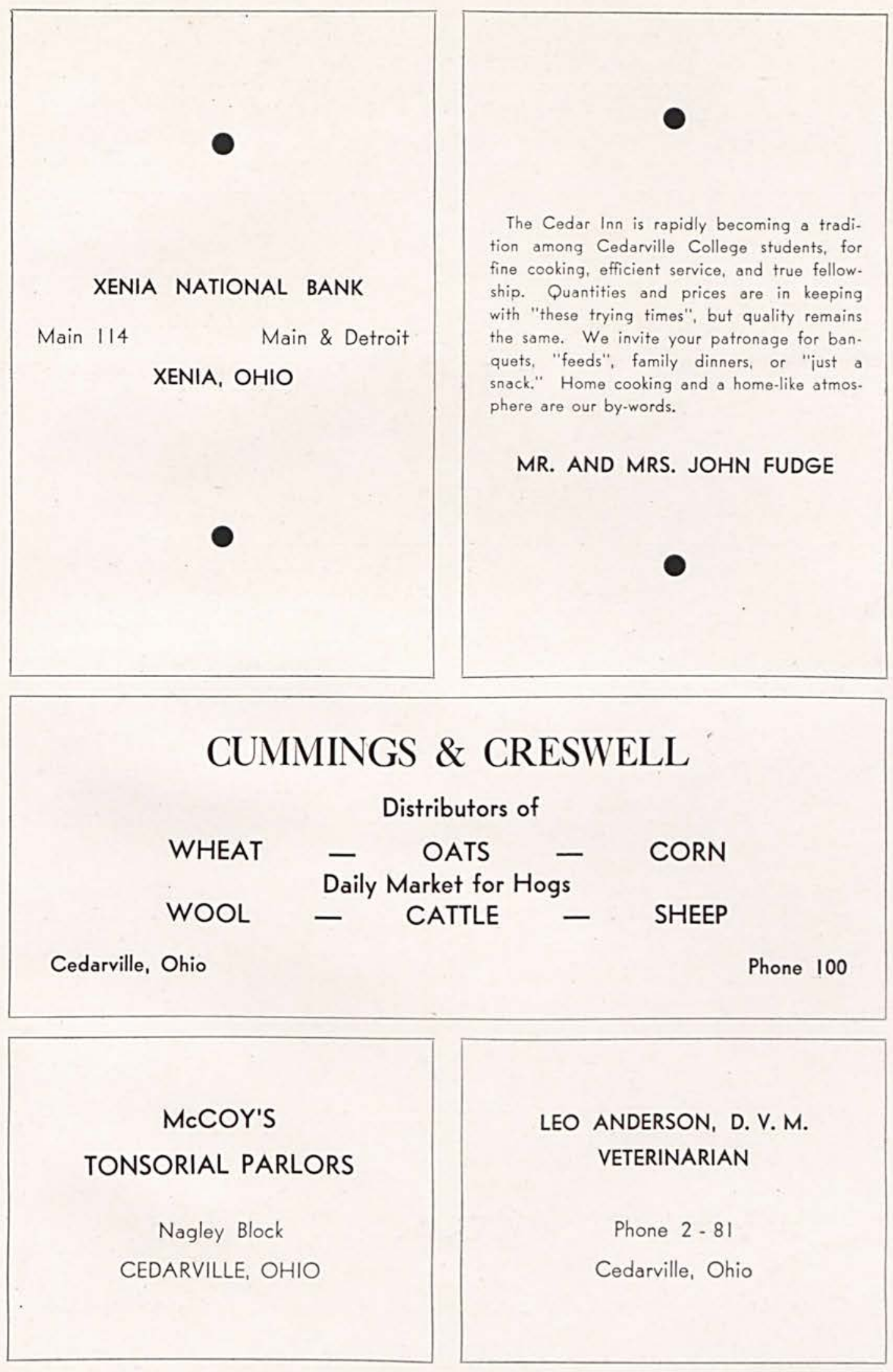

Page Seventy-three. 


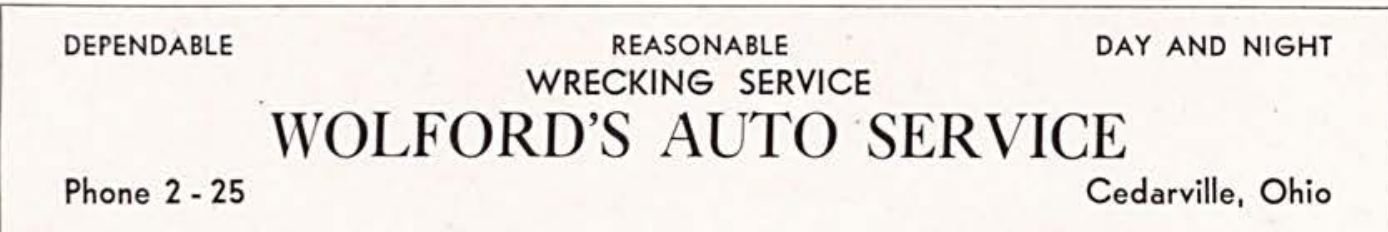
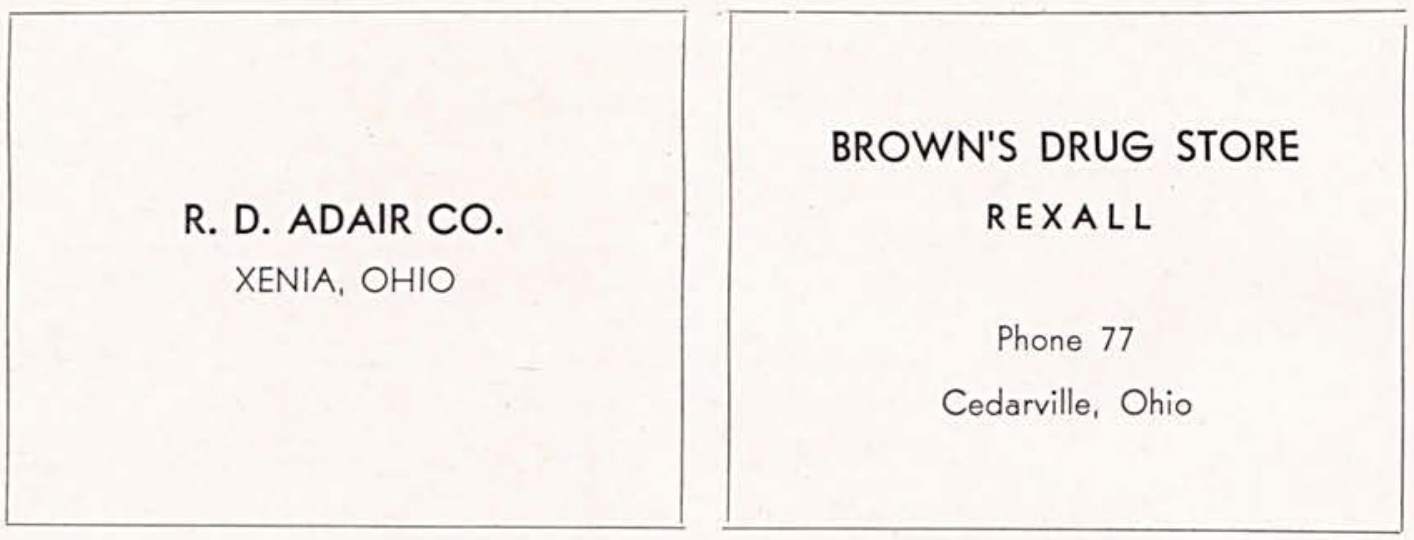

\section{COMMUNITY BEAUTY SHOPPE \\ Popular Prices \\ Frances Chase \\ Nagley Bldg., Xenia Avenue \\ OPEN EVENINGS BY APPOINTMENT \\ Phone 104}

Dec. 6. Pres. Roosevelt addresses Cedarville College - and the nation - over WLW.

Dec. 8. Cedarville College lassies play Selma. Win 27-20.

Dec. 9. Lebanon-first basketball trip. Holbrook, 29; Cedarville, 27.

Dec. 11. Miscellaneous recital at church.

Dec. 12. Hine and Burkert elected cheerleaders. Boys take Lutheran Church by surprise, $34-49$.

Dec. 14. Boys win again at Rio Grande, 43-30.

Dec. 17. Christmas Cantata.

Dec. 18. Registration. Secret Pal Party at E. Bull's.

Dec. 19. Frosh feed at 4:30 A. M.- and did they get smoked out?

Dec. 20. Freshmen smell like smoke. Upper classmen crippled.

Dec. 31. Vermont meets Ohio.

\section{NAGLEY'S GROCERY STORE}

GROCERIES

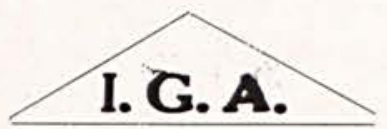

MEATS

Cedarville, Ohio

Phone 104

Cedarville, Ohio

Page Seventy-four 


\section{THE CRITERION \\ VALUE FIRST CLOTHIERS \\ XENIA, OHIO}

Jan. 3. School once again.

Jan. 4. Y.M.C.A. World's Fair. Trubee trips the light fantastic.

Jan. 8. Red Murray goes out and Paul Rife enters the realms of politics.

Jan. 9. Monks give talk on peace.

Jan. 10. Y. W. and Y. M. meet. Wilberforce entertains. Bowman escapes.

Jan. II. C. W. A. for teachers.

Jan. 13. Bluffton-Cedarville game. Lost 38-35. Girls lost to Inds., 10-15.

Jan. 15-16-17. Exams. 'nuff said.

Jan. 20. Rio Grande vs. Cedarville. We won 28-32.

Jan. 22. Final registration, marks distributed, and bills paid(?).

Jan. 23. Cedarville goes to Wilmington. Lost 38-29.

Jan. 25. Rush party.

Jan. 27. Cedarville loses to Findlay.

Jan. 29. Seven below zero. School paper published.

Jan. 30. Y's bring Dr. Cotton.

Jan. 31. Rabbi Tarshish speaks at Opera House.

Feb. I. Day of Prayer. Rev. Halsey speaks.

Feb. 3. Alumni Banquet. Boys play Defiance-three overtimes - ends in our favor, 44-43.

Feb. 4. Prohibition talk by Gospel Team at U. B. Church, Xenia.

Feb. 6. Wilberforce-Cedarville game; 42-31 in favor of visitors.

Feb. 7. Y. W. Cabinet Meeting (important secrets to be known later).

Feb. 9. College girls defeat C. W. A. team 20-8.

Feb. II. Linton entertains Gospel Team.

Feb. 15. Special features of radio stars, at Cedarville Theater. Junior Class Feed at Bull's.

Feb. 17. Team decides to remain in cellar position by one point margin with Defiance.

Feb. 21. Wilmington-Cedarville game. Same ole story.

Feb. 23-24. Debaters go to North Manchester.

Feb. 27. Twenty below.

Feb. 28. Cedarville Inds. girls play Reserves. Cedarville-Wilberforce, 45-40.

\section{THE CEDARVILLE HERALD \\ Commercial - Catalog \\ JOB PRINTING}

LET US GIVE YOU AN ESTIMATE ON YOUR PRINTING 
Mar. 2. Y.W.C.A. Wedding Gown Parade and Quilt Display.

Mar. 7. Intramural tournament. Freshmen champions.

Mar. 8. Moorehead-Cedarville Debate.

Mar. 13. "Your Lips Betray" sponsored by Junior Class.

Mar. 15. "Mother Mine" given by H. S.

Mar. 16. Mock Wedding. Who said girls couldn't keep anything to themselves? Mar. 16-17. Wilberforce tournament.

Mar. 18. Miss Basore entertains Gospel Team at her home in Carlisle.

Mar. 19. Girls have gym in peace.

Mar. 22. "Blarney Street". Oh me tumors!

Mar. 24. News out about Ault.

Mar. 25. The Monks are prisoners at the London Prison Farm.

Mar. 26. Minstrel Practice begins.

Mar. 27. Literary musical program.

Mar. 28. Big time for Coach and his wife. Wedding bells!

Mar. 29. Spring recess begins.

April I. April fool! Easter Cantata at M. E. Church.

April 3. Spring recess ends.

April 5. Found Mary Linton's model T in Cappel's truck!

April 6. Big time in South Charleston.

April 8. Bible Reading Contest for women. Esther Waddle takes first place.

April 11. Cedar Day practice begins.

April 12. Minstrel goes over big! Smith elected May Queen, and Kilpatrick, orator. April 13. Johnny M. comes to school backwards.

April 17. Rio Grande Debates, home and away. Negative won.

April 26. Dr. McKinney, C.C.'s President-Emeritus, dies unexpectedly.

April 30. Dr. and Mrs. McChesney's Reception.

May 11. Last classes for seniors.

May 18. College Picnic.

May 23-25. Final examinations.

May 27. Baccalaureate Services at Presbyterian Church.

May 29. Cedar Day.

May 30. Faculty Reception and pageant by students.

May 31. "The Thirteenth Chair"-Senior Class Play.

June 2. Commencement Speaker, Dr. M. Earle Collins, C. C., '23.

The End of a Perfect Year

\section{AN APOLOGY}

If your name does not appear on some list of past presidents of one of the college organizations where it may have earned its place, please do not feel that the omission was intentional. Records are lacking in most instances, and we have to depend upon the memory and patience of many of our good alumni friends for even the partial lists we have been able to compile.

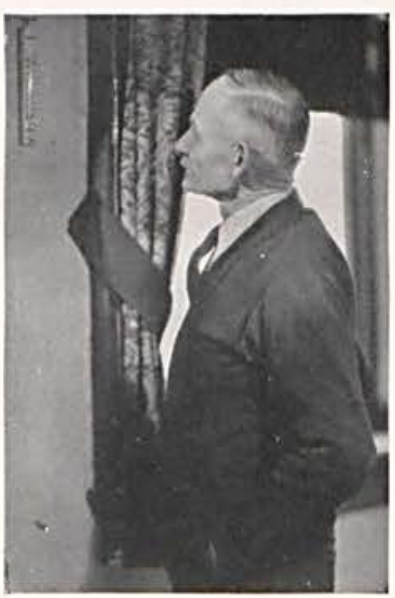

FRANK OWENS, Janitor 
IN THE 1934 "CEDRUS"-

ENGRAVING

By

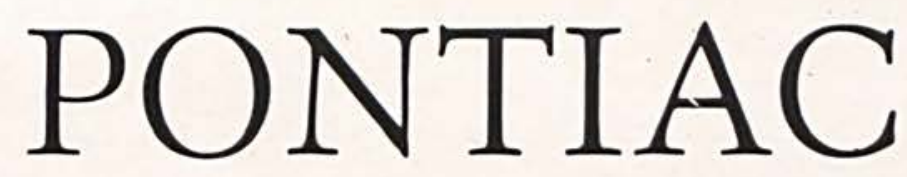

812-822 W. Van Buren St. (Chieftain Bldg.)

CHICAGO, ILLINOIS 


\section{AUTOGRAPHS}


AUTOGRAPHS 
AUTOGRAPHS

Page Eighty 
$\therefore$

.$$
2
$$ 


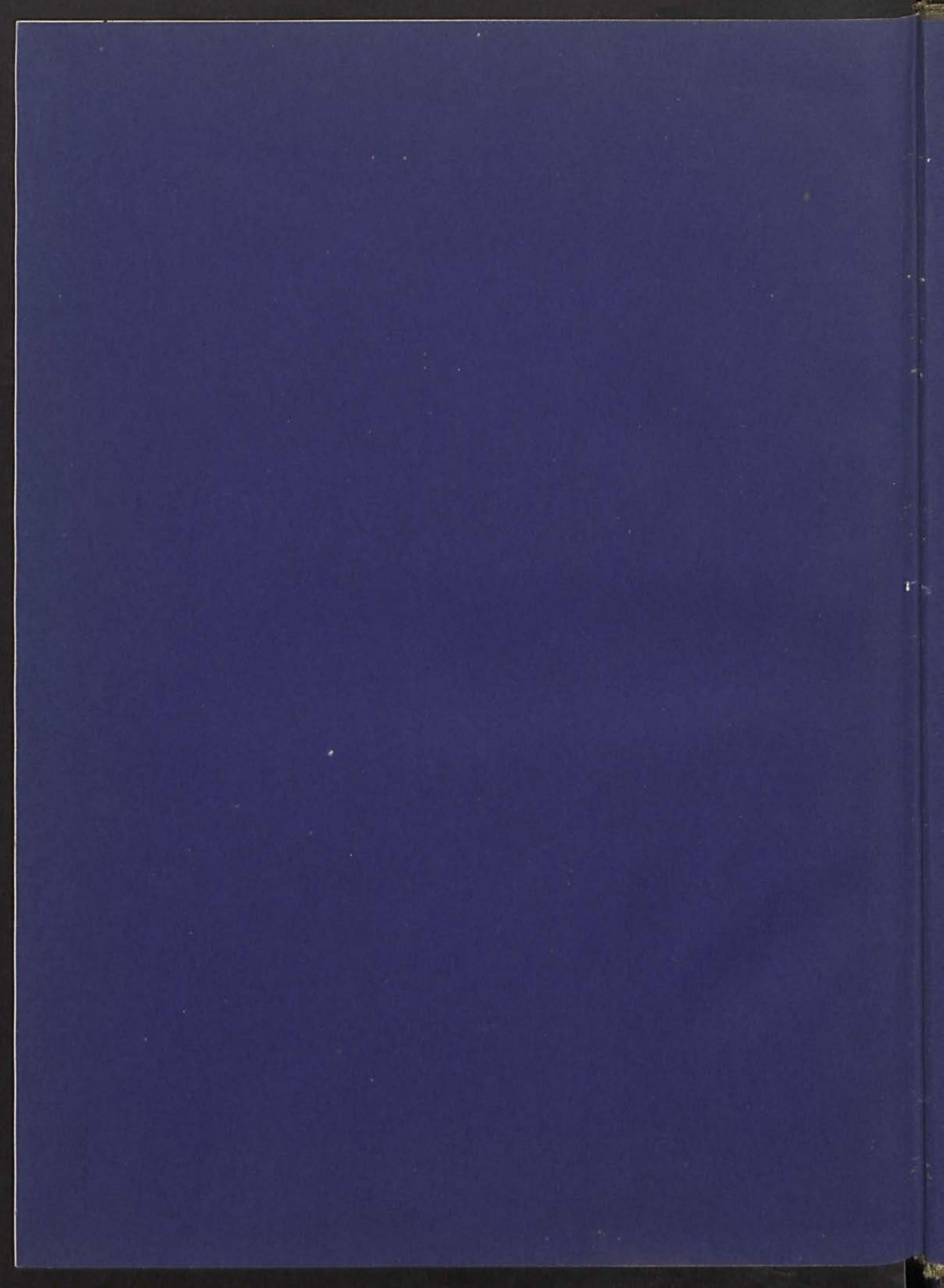




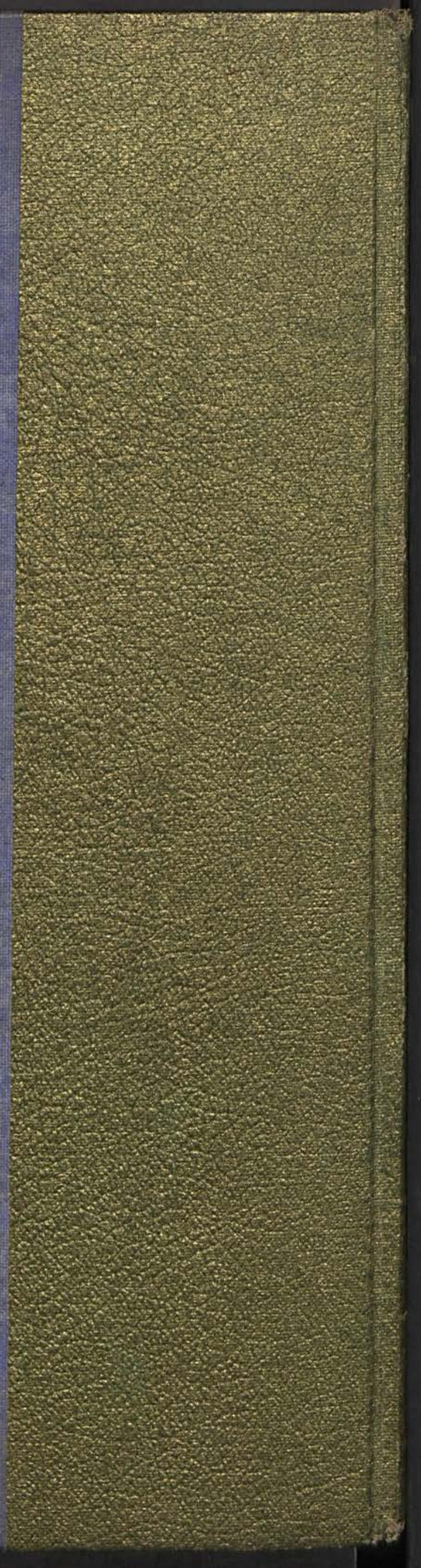

